2167 taxa. This is about the same number of taxa as may be found in one of the states of the United States.

\title{
MATERIALS TOWARD A MONOGRAPH OF THE GENUS VITEX. V
}

Harold N. lioldenke

\section{VITEX Tourn.}

Additional synonymy: Vitax Noldenke, Indic. Taxon. Ass. Sudam. Fitotax. 1 (2): 3, sphalm. 194l. Lagasca Née ex koldenke, Alph. List Invalid Names Suppl. 1: 11, in syn. 1947 [not Lagasca Cav., 1803].

Additional literature: L'Obel, Pl. Stirp. Icon. 2: 139. 1581; Delechamp, Hist. Gen. P1. 1867. 1586; Orta, Hist. Drogues, ed. 2, 115--116. 1619; Castelli, Hort. less. 24. 1640; J. Bauhin, Fist. P1. Univers. I (6): 205 (1.650) and 2: 189. 1651; C. Bauhin, Pinax Theatr. Bot. 412 \& 475. 1671; Rheede, Hort. Ind. Nalab. 2: 13--15, pl. 11 \& 12 (1679), 4: 75--76, pl. 36 (1633), and 5: 1-4, pl. I \& 2. 1635; Ray, Hist. PI. 3: 1575. 1688; Plukenet, Alm. Bot. 390, pl. 206, fig. 5. 1696; Cupani, Ilort. Cathol. Suppl. Alt. 6. 1697; Plukenet, Mlm. Bot. Phyt. 5: pl. 321, fig. 2. 1700; Zannich., Opusc. Posth. 21. 1730; Burm., Thes. Zeyl. 229, pl. 109. 1737; Rumph., Herb. Amboin. 3: 28, pl. 14, and 4: 1,3--50, pl. 13 \& 19. 1743; I., Fl. Zeyl., ed. 1, 194--195 [cenus 414]. 17L7; L., M1. Zeyl., ed. 2, 195. 1748; Ira-ri [transl. Savatier], Arbor. 2: pl. 6. 1759; lili., FiE. Pl. 2: 133, pl. 275. 1760; L., Sp. Pl., ed. 2, 390. 1763; Iill., Gard. Dict., ed. 3, nos. $1--5$ \& in errat. 1768; N. L. Burman, Fl. Ind. 137, pl. 43. 1768; iest., Univ. Bot. 1: 311--312. 1770; Houttuyn, Hand. P1. \& Kruidk. 5: pl. 27, fiE. 1. 1776; DC. \& Lam., Fl. Franc. 2: 363. 1773 ; ledic., Act. Hist. Comm. Acad. ilect. Theodoro-Palat. 4 (Phys.): 202, pl. 8 [Bot. Beobacht.] 1730; I. f., Suppl. PI. 293--294. 1781; Thunb., F1. Jap. 257. 1734; Sw., Prodr. Veg. Ind. Occ. 93. 1783; Lam., Incycl. liéth. Bot. 2: 612--613. 1733; Lour., Fl. Cochinch., ed. 1, 2: 84 \& 387--391. 1790; Nilld. in Cothen., Dispos. Veg. 8. 1790; Noronha, Verh. Batav. Gen. 5, ed. 1, art. 4: 86. 1790; Lour., FI. Cochinch., ed. Villd., 476. 1793; Vahl, Symb. Bot. 3: 85. 1794; Poir. in Lam., Tabl. Encycl. pl. 54l, fig. 2. 1794; Salisb., Prodr. Stirp. Hort. Allert. 107. 1796; Curtis, Bot. Kag. 1l: pl. 364. 1797; Raeusch., Nomencl. Bot., ed. 3, 178. 1797; Vall, Eclog. Amer. 2: 49--50, pl. 18. 1793; Willd. in Rottl., Gesell. Naturforsch. Freund. Berlin, leue Schr. 4: 203. 1803; lirbel, liist. 17at. P1., ed. 3, 15: 206, pl. 103. 1805; Pers., Syn. P1. 2: 144 \& 173. 1306; 1. L. Juss., Ann. Nus. Nat. Hist. Paris 7: 70 \& 76-77. 1306; licDonald, Pract. Gard. 2: pl. 60. 1307; Villd., Enum. Hort. Berol. 660. 1809; R. Br., Prodr. Fl. Nov. Holl., ed. 1, 1: 511- 512. 1310; Duham., Traité Arbres \& Arbust., ed. 2, 6: 115--116. 1812; S. Edwards, 
New Bot. Gard. 2: p1. 60. 1312; Ait., Hort. Kew., ed. 2, 4: 67. 1812; W. Ainslie, llat. Ked. Hind. 95. 1313; Loisel., Nouv. Duham. 6: 116. 1813; Roxb., Hort. Beng. 46. 1814; G. F. W. Vey., Prim. Fl. Esseq. 213--220. 1818; H.B.K., Nov. Gen. \& Sp. PI. 2: 245246 [ed. pict. 199--200]. 1818; Roxb., Tl. Ind., ed. 1, 43I--482. 1820; Curtis, Bot. Nag. 47: pl. 2187. 1820; Roth, Nov. Pl. Sp. $316-31 \%$ 1821; R. Br., Prodr. Fl. Nov. Holl., ed. 2, 1: 311512. 1321; Poir. in Lam., Tabl. Encycl. 3: y2, pl. 54l, fig. 2. 1823; Spreng., Syst. Veg. 2: 756-757 \& 842. 1325; Vell., Fl. Flum. 261--262. 1825; Thunb., FI. Javan. 11. 1825; Sweet, Hort. Brit., ed. 1, 323. 1826; Blume, Bijdr. i4: 812-814. 1826; W. Ainslie, Mat. Ked. Ind. 2: 252. 1826; Schum. \& Thonn., Kon $1 .-$ dansk. Videersk. Salsk. Afh. 4: 63. 1827; Schum. \& Thonn, in Schum., Beskr. Guin. P1. 62 \& 288--290. 1827; Vell., Fl. Flum. Icon. 6: pl. 82 \& 33. 1827; R. Br., Prodr. Fl. Nov. Holl., ed. 3, 1: 511--512. 1827; Spreng., Syst. Veg. 4 (2): 237. 1827; Duby in P. DC., Bot. Gal., ed. 2, 1: 375--377. 1828; Wall., Numer. List [48], nos. 1745-1760. 1829; Loud., Encycl. P1. 520. 1329; Desf., Cat. Hort. Paris, ed. 3, 391. 1829; B. R. Slade, Horticulture, ser. 2, 8: 552. 1830; Cham., Linnaea 7: 107 \&: 371-400. 1832; Wall., Pl. Asiat. Rar. 3: pl. 226. 1832; Wall., Numer. List 215, no. 6314. 1832; Roxb., Fl. Ind., ed. 2 [Carey], 3: 70--75. 1332; Bunge, Ném. Sav. Etr. Acad. Sci. St. Petersb. 2: 126 [Enum. Pl. Chin. Bor. 52] . 1833; Kostel., Allg. Led.-pharm. Fl. 3: 826. 1834; Decne., Nouv. Ann. lius. Paris 3: 401. 1834; Silva-lanso, Enum. Subst. Braz. 36. 1836; Hook., Comp. Bot. .Mag. 1: 349. 1836; Hook. \& Arn., Bot. Beech. Voy. 206. 1836; Blanco, Fl. Filip., ed. 1, 513--516. 1837:, Turcz., Bull. Imp. Soc. Nosc. [Enum. China no. 164] 7: 156. 1837; E. Ney., Comm. P1. Afr. Austr. 1: 273. 1837; Bojer, Hort. liaurit. 258. 1837; Loud., Arb. Brit. 3: 1236. 1338; A. DC., Rev. Fam. Bignon. 16. 1333; Sweet, Hort. Brit., ed. 3, 551. 1839; Royle, Illustr. Bot. Himal. 299. 1339; Benth. in Hook., Journ. Bot. 2: 53. 1839; J. Taylor, Sketch Topog. \& Stat. Dacca 55. 1840; Hook. \& Arn., Bot. Beech. Voy. 305 (18LO) \& pl. 47 \& 48.18 Ll; Spanoghe, Iinnaea 15: 329-330. 13l.1; 0'Shaughnessy, Beng. Dispens. 484--485. 1841; Steud., Nom. Bot., ed. 2, 2: 712. 1841; liart., Syst. llat. lied. Brasil. 55. 1343; Wight, Icon. Pl. Ind. Or. 2: pl. 519. 1843; Walp., Repert. 4: 84--92. 1844; Iiq., Linnaea 18: 739. 1844; Benth., Bot. Voy. Sulphur 10 \& 155. 1844; Blanco, Fl. Filip., ed. 2, 358--360. 1845; Zoll. \& Noritzi, Syst. Verz . 53. 1845--1846; Sieb. \& Zucc., Abh. Akad. linch. 3 (4): 152. 1346; Schau. in A. DC., Prodr. 11: 682--695. 1847; Linnaea 20: 483. 1847; Nees in A. DC., Prodr. 11: 218 \& 245. 1347; Irvine, Short Acct. Nat. Ned. Patna 77 \& 118. 1348; Lindl., Ned. \& Oeconom. Bot. 223. 1849; Wight, Icon. P1. Ind. Or. 4: pl. 1465--1467. 1849; Schau. in kart., Fi. Bras. 9: 294--302, 307, \& 320--321, pl. 49. 1851; Griff., Notul. 4: 178 (1851) and 740. 1854; Griff., Ic. Pl. Asiat. pl. 448, fig. 2. 1854; Seem., Bot. Voy. Herald 8: $329 \& 355$, pl. 71. 1956; Seem., Bonolandia 4 : 128. 1856; Miq., Fl. Ind. Bat. 2: 853--365. 1856; Drury, Useful P1. India 442--443. 1358; Welw., Apont. Phyto-geogr. Angola 585. 1853; W. Elliot, Fl. Andhr. 32, 124, 
128, 134, 180, \& 190. 1859; Tornabene, Atti Accad. Gioena Sci. Nat. Catania, ser. 2, 16 [Fl. Foss. Etna] : 118--126, pl. 3, fig. A'. 1860; Miq., Fl. Ind. Bat. Suppl. 1: 242 \& 567--568. 1860; Nason, Burmah \& its People, ed. 2, 526 \& 792. 1860; Dals. \& Gibs, Bombay Fl. 201. 1861; Ettingsh., Blatt-Skelet. Dikot. 79, pl. 32, fig. 6. 1861; Griseb., Fl. Brit. West Ind. 502. 1861; Baill., Adansonia 2: pl. 6. 1861--1862; Seem., Trans. Linn. Soc. Lond. Bot. 23: 9--14. 1362; Peters, Reise Nossamb. 26L--265. 1362; Griseb., Pl. Wright. 2: 530. 1862; Hassk., Ilort. Nalab. Clzv. 38. 1362; F. Nuell., Fragm. 3: 59. 1862; Van Tjiandjoer, Genees. Yundig Tijdsch. 1: 690. 1862; Seem., Viti 440. 1862; Turcz., Bull. Soc. Imp. Nat. Nosc. 36 (2): 223--225. 1363; Thwaites, Enum. P1. Zeyl. 244--246. 1364; Birdwood, Cat. Veg. Prod. Bomb. 66 \& 335. 1865; F. Wuell., Fragm. 5: 35--36. 1365--1366; Griseb., Cat. P1. Cub. 113 \& 216. 1866; Kotsch. E: Peyr., Pl. Tinn. 27, pl. 12. 1867; llann, Proc. Am. Acad. 7: 194. 1867; Ettingsh., K. Akad. Wiss. Wien Denkschr. 28: 219 [Fossile Flora Bilin 2: 3132], pl. 37, fig. 4. 1868; Hance, Journ. Bot. 6: 115. 1868; Sauv., Fl. Cub. 113. 1868; Benth. \& luell., Fl. Austral. 5: 31 \& 58-67. 1870; Kurz, Rep. Veget. Andaman Isls. App. A: 45 \& B: 14. 1870; Carr., Rev. Hort. 42: 415--416. 1871; Baker in Mart., F1. Bras. 14 (2): 212. 1871; Brandis, For. Fl. NW. \& Cent. India 3: 369-370. 1874; Carr., Rev. Hort. 45: 499. 1874; Oliv. Trans. Linn. Soc. Lond. Bot. 29: 132--134, pl. 130 \& 131. 1875; Gribble, Cuddapah Dist, Man. 65. 1875; F. Muell., Fragm. 9: 5. 1875; Hook. f., Bot. Mag. 102: pl. 6230. 1876; Engelhardt, Nova Acta K. Leopold.-Carol. Deutsch. Akad. Naturf. 38: 362, pl. 18, fig. 5. 1876; Debeaux, Act. Soc. Linn. Bordeaux 31: 346 [Fl. Tchéfou 113]. 1876; J. G. Baker, Fl. Maurit. \& Seych. 255-256. 1877; Kurz, For. Fl. Brit. Burma 2: 269--273. 1877; Ind. Forester 3: 23, 178, \& 204. 1877; Gazetteer Bombay 6: 15. 1877; Dutt, Mat. Med. Hind. 216, 311, \& 318. 1877; Blanco, Fl. Filip., ed. 3, 2: 297--300, pl. 226--228 \& 427. 1878; Gazetteer Bombay 7: 42. 1878; Ind. Forester 4: 338. 1878; [Dera Ismail Khan] Dist. Gazetteer 19. 1878; [Kohat] Dist. Gazetteer 30. 1379; Debeaux, Act. Soc. Linn. Bordeaux 33: 59 [Fl. Tien-tsin]. 1879; Rajputana Gazetteer 26. 1879--1880; F.-Vill. in Blanco, Fl. Filip., ed. 3, Nov. App. 160. 1880; Gamble, Nan. Ind. Timb. 297--298. 13381; Vatke, Linnaea 43: 507--535. 1882; J. G. Baker, Journ. Bot. 20: 221--222. 1882; Ind. Forester 8: 29. 1382; Franch., Ném. Soc. Nat. Cherbourg 24: 24 [Cat. Pl. Tché-fou]. 1382; Velenovsky, K. BOhm. Gesell. Wiss. Sitzungsb. 1381: 213. 1882; F. Vuell., First Census 103. 1332; J. G. Baker, Journ. Linn. Soc. Lond. Bot. 20: 159 \& 221--228. 1883; F. L. Bailey, Syn. Queensl. Fl. 379. 1883; Franch., Nouv. Arch. Lus. Paris, sér. 2, 6: 112 [P1. David. 1: 232]. 1883; Vidal, Sin. Fam. \& Gen. Pl. Lef. Filip. [Introd. Fl. For. Filip.] Atlas pl. 75, figs. A-C. 1833; Ind. Forester 10: 31, 33, \& 222. 1884; Sinclair, Indig. Fl. Hawaii. Isls. pl. 26. 1835; C. B. Clarke in Hook. f., Fl. Brit. Ind. 4: 583--588. 1385; Dymock, Veg. Vat. lied. West Ind., ed. 2, 600. 1885; Hemsl., Scient. Res. Voy. Challenger Bot. I: 110 \& 173. 1885; J. G. Baker, Journ. Linn. Soc. Lond. Bot. 21: 407 \& 434--435. 1885; 
Rep. For. Admin. Chutia Nagpur 33. 1885; Gazetteer Bombay 15: 78 . 1886; Kaxim., Bull. Acad. Imp. Sci. Pétersb. 31: 82. 1886; Maxim., Mel. Biol. 12: 516. 1886; A. Gray, Proc. Am. Acad. 21: 407. 1386; J. C. Lisboa, Useful PI. Bombay 108-109 \& 201. 1886; Ind. Forester 12: 551 \& App. 19. 1886; Gazetteer Bombay 17: 25. 1888; Hillebr., Fl. Haw. Isl. 342. 1888; Baill., Bull. Soc. Iinn. Paris 1: 714. 1888; T. Kirk, For. Fl. New Zeal. pl. 105. 1889; F. Muell., Second Census 173. 1889; Sessé \& Moc., La Naturaleza, ser. 2, 1: app. 103 \& 133. 1889; J. G. Baker, Journ. Linn. Soc. Lond. Bot. 25: 294 \& 340--34l. 1890; Schinz, Verhandl. Bot. Ver. Brand. 31: 206. 1890; F. M. Bailey, Cat. PI. Queensl. 35. 1890; Buttn., Verhandl. Bot. Ver. Brand. 32: 35. 1890; Forbes \& Hems1., Fl. Sin. 2: 257-258. 1890; Douie, [Karnal] Dist. Gazetteer 16. 1890; Hemsl., Journ. Linn. Soc. Lond. Bot. 26: 257-258. 1890; Schimper, Bot. Mitteil. Trop. 3: 129. 1891; J. G. Baker in Buchanan, Nyasaland PI. 15. 1891; Fawcett, Econom. P1. 76. 1891; S. Elliot, Journ. Linn. Soc. Lond. Bot. 29: 42. 1891; Kuntze, Rev. Gen. P1. 2: 510--511. 1891; Gazetteer Karnal Dist. 16. 1892; Lubbock, Seedlings 2: 372. 1892; J. G. Baker, Kew Bull. 1892: 198. 1892; Gurke in Engl., Bot. Jahrb. 18: 165-171. December 1893; Noore, Handb. Fl. New South Wales 357. 1893; Fawcett, Provis. List Indig. Nat. Flow. PI. Jamaica 30. 1893; G. Watt, Dict. Econom. Prod. India 6 (4): 200-251. 1893; Jacks., Ind. Kew. I: 582. 1893; Rolfe, Bolet. Soc. Brot. 11: 87. May 1893; Koehne, Dendrol. 526. 1893; Bois, Dict. Hort. 1208. 1893--1899; Harris, New Zeal. Berries [pl. 1]. 1894; Britten, Trans. Linn. Soc. Lond. Bot., ser. 2, 4: 36. 1894; Gurke in Engl., Bot. Jahrb. 18: 166. 1894; Robinson \& Pringle, Gard. \& Forest 7: 153. April 13, 1894; B. L. Robinson, Proc. Am. Acad. 29: 321. 1894; Trimen, Handb. F1. Ceylon 3: 357. 1395; Jacks., Ind. Kew. 2: 1121 \& 1213--1214. 1895; Engl., Pflanzenw. Ost-Afr. C: 339--340. 1395; Bull. Coll. Agric. Tokyo 2: pl. 18, fig. 17. 1895; Briq. in Engl. S Prantl, INat. Pflanzenfam. 4 (3a): 132, 170, 172, \& 178. 1895; Useful P1. Jap. 2: pl. 447. 1895; Briq., Buli. Herb. Boiss., sér. 1, 4: 346-347. 1896; Gurke, Bull. Herb. Boiss., sér. 1, 4: 818 . 1896; Durand \& Schinz, Etud. Fl. Congo 222. 1896; Nillsp., Field wus. Publ. Bot. 1: 317. 1896; T. Kirk, Trans. New Zeal. Inst. 29: 525. 1897; Bur. \& K. Schum. in Nart., Fl. Bras. 8 (2): 289. 1397; Lorimer, [Peshawar] Dist. Gazetteer 27. 1897-1898; Koord., Meded. Lands Plant-tuin Buitenz. 19: 560 \& 645. 1898; Kuntze, Rev. Gen. Pl. 3 (3): 258. 1898; Cummins, Kew Bull. 1898: 76-77. 1393; Durand \& Dewild., Bull. Soc. Bot. Belg. Compt. Rend. 38: 133--134. 1899; Henriques, Bol. Soc. Brot. 16: 69. 1899; J. I. Stewart, Punjab P1: 166--167. 1899; Natsum., Bot. Nag.' Tokyo 13: 121--122. 1899; K. Schum. \& Lauterb., Fl. Deutsch. Sudsee 523-524. 1900; Gurke in Engl., Bot. Jahrb. 28: 291 \& 461-464. 1900; Gurke, Notizbl. Bot. Gart. Berlin 3: 76. 1900; Hiern, Cat. Afr. P1. Welw. I (4): 827 \& 834--838. 1900; Koord. \& Val., Bijdr. Booms. Java 7: 200-210. 1900; J. G. Baker \& Stapf in Thiselt.Dyer, Fl. Trop. Afr. 5: 273--331 \& 520--521. 1900; Deilild. \& Durand, Contr. Fl. Congo 2: 39 \& 50. 1900; Diels in Engl., Bot. Jahrb. 29: 549. 1900; H. H. W. Pearson in $\mathrm{T}_{\mathrm{h}}$ iselt.-Dyer, Fl. 
Cap. 5 (1): 180 \& 211--214. 1901; Dewild. \& Durand, Reliq. Dewev. 134--135. 1901; Ahern, Philipp. "loods 69. 1901; Beauvis., Gen. lontrouz. 66--68. 1901; A. IC., Bull. Herb. Boiss., ser. 2, 1: 531. 1901; Rehd. in L. H. Bailey, Cycl. Am. Hort. L: 19l47--19L1,3. 1902; Barnhart, Bul]. Torrey Bot. Club 29: 597. 1902; Gurke in Engl., Bot. Jahrb. 32: 1143. 1902; Gurke in Baum, Kunene-Sambesi Exped. 350. 1903; lak., Dot. llag. Tokyo 17: 92. 1903; Deilild., Itud. Fl. Katanga 121. 1903; Gurke in ingl., Dot. Jahrb. 33: 292299. 1904; Thiselt.-Iyer, Ind. New. Suppl. 2: 193--19/4. 1904; Iriq., Mrkiv Bot. 2 (10): 22. 190L; Gilg 3 Loes. in Enel., Bot. Jahrb. 34, Eeibl. 75: 62. 1904; F. ... Bailey in Keston, Exped. Bell-Yer (Parliam. Rep.) 14. 1904; 2. D. Nerr., Dur. Govt. Lab. Philipp. Dull. 6: 17--13. 1204; Kine 2: Gamble, "at. H1. Walay Penins. 354--357. 1305; E. D. Lerr., Dur. Covt. Tab. Philipp. Sul1. 27: 63. 1905; K. Schum. 2: Lauterb., Nichtr. FI. Deutsch. Stuàsee 362. 1905; F. I.. Villiams, Bull. lierb. Doiss., sér. 2, 5: 1431. 1905; Dewild., ttud. Fl. Las- d...oyen-Conco l: 193 \& 309. 1906; Cheeseman, lian. Hew Zeal. Fl. 565. 1906; Gibbs, Journ. Linn. soc. Lond. Bot. 37: 463 \& 575. 1906; Durand \& Jacks., Ind. Kew. Suppl. 1: 449 i 457. 1906; Deifild., Ic. Sel. Ilort. Then. 5: pl. 199. 1906; Ricil., Journ. Roy. As. Soc. Straits 45: 50. 1906; Ilausskn. in Bornm., P1, Strauss. 3: 117. 1907; Greenm., Field Lus. Publ. Bot. 2: 260--261. 1907; Sim, For. Hl. Cape Colony 237, pl. 120. 1907; Kloppenburg-Versteegh, Pl. At]as pl. 15. 1907; S. lioore, Journ. de Bot. 45: 94 í 154. 1907; Bornm., Beih. Bot. Centralbl. 22 (2): 113. 1907; Bol. Ort. Bot. Palermo 6: pl. 2. 1907; Laing \& Blackwell, PI. New Zeal., ed. 2, 351. 1907; lildbr. in Von lecklenb., Ergebn. Deutsch. Zentral-AIrik. Exped 1: 231. 1907--1903; C. H. Wright, Kew Bull. 1903: 437. 1903; King \& Camble, Kew Bull. 1903: 112--113. 1908; Pavolini, luov. Giorn. Bot. Ital., n. ser., 15: 432. 1003; Hayek, Denkschr. Kais. Akad. Vissen. Vath.-nat. 79 (I): 296. 1908; E. D. Verr., Journ. Philipp. Sci. Bot. 3: 432. 1903; Prain, Ind. Kew. Suppl. 3: 139. 1903; Ying \& Gamble, Journ. As. Soc Eeng. 74: 343--357. 1909; Luber, Bol. Lus. Goeldi [Ius. Para.] 5: 209--222, pl. 1--4. 1909; Sim, For. Fl. S Res. Port. Wast Afr. 93--9 L, pl. 733. 1209; Durand, Syllog. Tl. Congol. 436--137. 1909; . D. .err., Philipp. Journ. Sci. Bot. L: 320. 1709; Dellild., Arn. .us. Conö, sér. 5 [itud. Pl. Bas- : Voyon Congo] 3: 127--131. 1909; ilaz., ckm. Soc. Dot. Wrance 3: 547. 1909; A. Chev., Véc. Util. Afr. Trop: Franc. 256. 1909; De:iild., Dtud. I1. Las- Koyen-Conco 3: 255

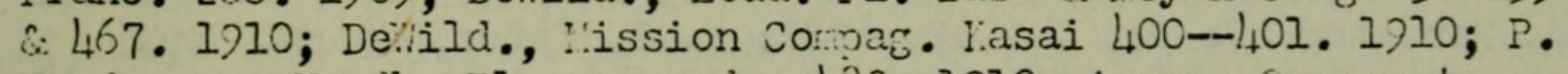
Henderson, Handb. PI., new ed., 432. 1910; Apsar, Ornament. Shrubs U. S. 290, fig. 507. 1910; loord., PI. Jungh. L: 133.

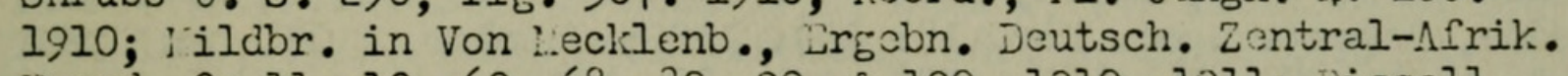
Exped. 2: 11--12, 62, 68, 30, 90, \& 190. 1010--1911; Rissel1, Bean, \&: Vaughan, "iebster's Imperial Dict. 1373. 1910--1911; S. Noore, Journ. Linn. Soc. Lond. Bot. 40: 165--169. 1911; Gerth Van Wijk, Dict. Plantnames 1: 1/119--1/,20. 1911; C. K. Schneid., Illustr. Handb. Laubholzk. 2: 592--594, fig. $334 \mathrm{~m}$ \&: $\mathrm{n}$ and 335 5-t. 1011; Tectona 4: 393. 1011; Dewild., Etud. Fl. Banfala ix Ubangi $246--243$ \& 375 , pl. 12. 1911; Urb., Symb. Ant. 4: 537-- 
538. 1911; Talbot, For. Fl. Bombay 2: 355. 1911; iiyabe, Festschrift p1. 26, fig. 25. 1911; Wehmer, Die Pflanzenst., ed. 1, 647. 1911; K. E. Fries, Ergebn. Schwed. Rhodesia-Kongo-Exped. I: 273. 1912; Docters van Leeuwen, Bull. Jard. Bot. Buitenz., ser. 2, 3: 49. 1912; E. D. Nerr., Philipp. Journ. Sci. Bot. 7: 343. 1912; Koord., Exkursionsfl. Java 3: 136--137. 1912; Urb., Symb. Ant. 7: 357--358. 1912; E. H. Wils., Arn. Arb. Exped. China 1910--11, pl. 0202. 1912; latsum., Ind. 2 (2): 534. 1912; Elbert, Veded. Rijks Herb. Leiden 12: 16. 1912; Prain, Ind. Kew. Suppl. 4: 248. 1913; F. li. Bii ley, Compreh. Cat. 336. 1913; A . Chev., Etud. P1. Afr. Cent. Franc. 1: 243--244. 1913; Wernham, Cat. PI. Talbot Oban Dist. 91. 1913; Hand.-1:azz., Ann. Hofmus. Wien 27: 403. 1913; Deilild. in Fedde, Repert. Spec. Nov. 13: 141--143. 1914; Cheeseman, IIl. New Zeal. Fl. 2: pl. 161. 1914; Koord. \& Val., Atlas Daumart. Java 2: 6, pl. 20?--299. 1914; E. D. Jerr., Philipp. Journ. Sci. Bot. 9: 136. 1914; Yabe, Ic. Fl. Vanchur. I (1): pl. 10. 1914; Publicaties lied. Ind. Landb. Syndicaat 1914: 172. 1914; Turrill, Yew Bull. 1915: 47--48. 1915; Pittier, Contrib. U. S. Nat. Ilerb. 13: 170. 1916; Navarro de Andrada 2 Vecchi, Bois Indig. Så Paulo 230. 1916; 5. L. Robinson, Proc. Am. Acad. 51: 531. 1916; Lyles, Trans. Roy. Soc. south Afr. 5: 459. 1916; 7. T. Sm., 1.ot. Bot. Gard. Jdinb. 9: 141--11,2. 1916; Rehd. in Sarg., Pl. Wils. 3: 33. 1916; Bornm., Notizbl. Dot. Gart. Berlin 7: 25. 1917; A. Chev., Veg. Util. Afr. Trop. Franc. 230--231, pl. 25. 1917; L. If. Bail ley, Stand. Gycl. Hort. 6: 3431 \& 3574 . 1917; Lévl., Cat. P1. Yun-Nan 278. 1917; Kanehira, Formosan Trees 407. 1917; Hemsl. \& Turrill, J urn. Bot. 55: 235--236. 1917; Heyne, Nutt. Plant. Nederl. Ina., ed. 1, 4: 1.11--117. 1917; E. D. Nerr., Interpret. Rumph. Herb. Amboin. 453. 1917; Druce, Rep. Bot. Exch. Club Brit. Isls. 1916: 652. 1917; H. Hallier, I.eded. Rijks Herb. Leid. 37: 42--54. 1918; Basu, Ind. Ledic. PI. 3: 3, pl. 740--742. 1918; E. D. Nerr., Sp. Blanc. [Dept. Agr. Bur. Sci. Publ. 12:] 332--333. 1918; Gandoger, Bull. Soc. Bot. France 65: 64. 1913; Craib, Kew Bull. 1913: 367--368. 1913; Pellegrin, Bull. lius. Nat. $\mathrm{H}_{\text {; st }}$. Nat. Paris 25: 335. 1919; Van Gorkom, Oost-Ind. Cult., ed. 2, 3: 379. 1919; E. H. Vils., Arn. Arb. Exped. E. Asia 1917--18, pl. N-452. 1220; lenzel, Beitr. Geol. Brforscl. Deutsch. Schutz. 18: 30. 1320; A. Chev., 'xpl. Eot. Afr. Occid. Franc. 1: 505--507. 1920; Dose, lan. Ind. Dot. 131. 1920; Cortishley, Kew Eull. 1920: 333. 1920; H. J. Lam in Lam \& Eakh., Dull. Jard. Bot. Juitenz., ser. 3, 3: 1--120. 1921; Ind. Forester 4?: pl. 9 \&: 10. 1921; . L. Yates, Journ. Loy. Hort. Joc. Lond. L6: 337. 1221; De..ild., Contrik. N1. Natanga 67 is 164--165. 1.921; Prain, Ind. 1e:T. Sunpl. 5: 273. 1921; lrb. in Iedde, zopert. Seec. Nov. 18: 369. 1.922; Whecler, Jull. Am. :us. lat. list. 1,5: $44 l_{1}--152$ i 535, fic. 33. 1922; Naliai, Troos \& Shrubs Jap. 1: 350, fir. 170. 1722; 2. 2. : orr., Wilipp. Journ. Sci. Jot. 20: 433--439. 1.922; Nildkr., Uiss. Ergobn. voutsch.

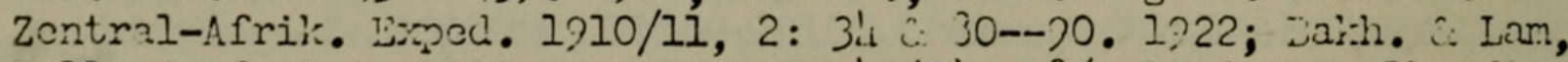
zull. Jard. zot. Juitenz., ser. 3, it (2): 23, . 1222; incolharct,

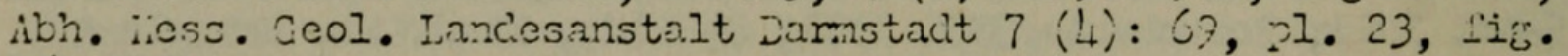
15. 1322; Jocters van Lecumon, Lull. Jard. Lot. Luitenz., ser. 3, 
4: 311 : 314. 1922; H. J. Lam, Bull. Jard. vot. Buitenz., ser. 3, 5 (2): 175--173. 1922; Deilild., Plant. Bequaert. 2: 255. 1922; Ricl., M1. lalay penins. 630--636 \& 671. 1923; Makai, P1. Sylv. Horeana 14: 37, p1. Il C 12. 1923; L. D. i.err., Znurn. Philipp. P1. 3: 391,--393. 1323; Popenoe, Contrib. U. S. Wat. Ierb. 2L: 133. 1924; H. J. Lam, INova Cuin. 11/: 169. 19214; Danourr, Dull. Jus. Nat. Hist. !lat. Paris 30: 503--509. 1924; Fries, Notizbl. Bot. Gart. Eerlin 3: 702. 1924; I. H. Eailey, lan. Cult. PI., ec. I, 632 \& 349 . 1924; lak., Ill. Fl. Jap. [217] \& [395]. 1924; Olnsted, Coville, \& Helsey, Stand. Pl. Names, ed. 1, 525. 1921;; Britton \& P. Wils., Scient. Surv. Porto Pico \& Virg. Isls. 6: 149. 1925; Galpin, Bot. Surv. S. Afr. lem. 7 [Nat. Timb. Trees Springbok] : 23--26, fig. 50. 1925; H. J. Lam in Lngl., Bot. Jahrb. 59: 27--23 \&: 92--93. 1925; Engl., Pflanzenw. Afr. 5 (1): [ingl. \& Drude, Veget. Erde 9:] 40, 46, 50, 139, 190, ¿ 192. 1925; Rendle, Journ. Lot. 63: Supp1. 31. 1925; Ducke, Arquiv. Jard. Iot. Rio de Janeiro 4: 172. 1925; Lely, useful Trees N... Nizeria 115. 1925; Heyne, Nutt. Plant. Nederl. Ind., ec. 2, 13151320. 1925; L. H. Bailey, Nan. Cult. Pl. [repr. 1], 632 is 3!!9. 1925; Yoore, Journ. Bot. 63: 236. 1925; Iill, Ind. Yew. suppl. 6: 219. 1926; Standl., Tron. Woods 8: 6. 1926; Nearer, Ann. Ius. Col. "arseille, sér. 4, 4: pl. 60. 1926; R. O. Nilliams, Guido Roy. Bot. Gard. Trinidad 30. 1927; Rehd., Ian. Cult. Trees, [ed. 1], 777. 1927; Iorticulture, ser. 2, 5: 350. 1927; Foxtorthy, Kalayan Forest liec. 3: 163. 1927; Rusby, l.em. l.ow York Dot. Gard. 7: 31,1--342. 1927; E. D. Lerr., Linmnan sci. Journ. 5: 159. 1927; Nakai, Trees \& Shrubs Indig. Jap., ed. 2, 1: 474--475, fics. 224 \& 990. 1927; Domin, Bibl. Bot. 22 (39-6): 1114--1il7, Ciss. 131 \& 182. 1923; D. Dois, PI. Aliment. 2: 440. 1923; Dor, Trav. Lab. For. Toulouse I (1): pl. 2--4. 1928; Croifoot, Flow. PI. ... 8. Jont. Judan pl. 1.43. 1923; Pieper in injl., Bot. Jahrb. '́2, Beibl. 141 ["1/42"]: 2--89, pl. 1--11. 1928; Dop, Dull. joc. List. Nat. Toulouse 57: 193-203. 1928; Freman Cililiams, useful 11. Trin. 167. 1923; I. C. Vercioorn, Union S. Afr. Dept. Agr. i Forest. Bull. 185: 45--46. 1923; Deililc., Plant. Wequaert. 5: 5--19. 1929; Uitten, Rec. Trav. Bot. Néerl. 25: pl. 3. 1929; Pope, Wayside Pl. Hawaii 196, pl. 11l. 1927; De ilici., Ann. Soc. Scientif. Brux. pl. 49, sér. B, p. 66. 1.929; Ridl., Kew Lull. 1929: 261--262. 1929; Pieper in Fedde, Repert. Spec. Nov. 26́: 1́́l--166. 1929; Devila., Contrib. Etud. Fl. 1 atanga Suppl. 2: 101--109. 1929; seckt, nev. Univ. Nac. Cordoba 17: 19 \& 36, pl.

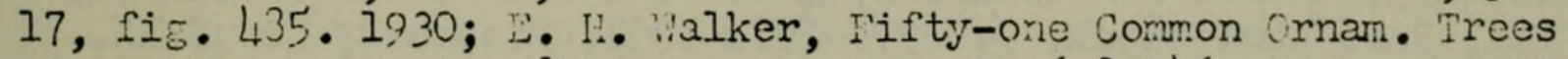
Iingnan Univ. Canton [Iingran Sci. Journ. 6:] 146. 1930; standl., Fielcl lus. Publ. Dot. 3: 40L. 1.23C; Sandw., I cvr Bull. 1230: 157-153. 1930; vull. Jard. Bot. Buitenz., sér. 3, 13: 25. 1930; Herter, Florvla 105. 1930; Stapf, Ind. Lond. 6: 473-L79. 1931; Ixell, Journ. Bot. 69: Suppl. 2: 1/15. 1931; Ilutchinson 2 Jalziel, Fl. W. Trop. Afr. 2: 277. 1931; Trop. Woods 27: 27. 1931; Wehmer, Die Pflanzenst., ed. 2, 1023. 1931; Cooper \& Record, Iull. Yale Univ. School lorestry 31: pl. 11. 1931; Vilcler, Jishop kus. Jull. 86: 23. 1931; Nonda A Sakisaka, Syst. P1. Canon. 362. 1931; Ducke, Notizbl. Dot. Gart. Berlin 11: 520-591. 1232; ?'ei, :eve 
Sci. Soc. China I (3) [Verbenac. China]: 93--114 \& 193, p1. 20 \&. 21. 1932; Noldenke, Bull. Torrey Bot. Club 60: 58--59. 1932; P'ei, Sinensia 2 (4): 71--74, figs. 1 \& 2. 1932; P'ei, Contrib. Eiol. Lab. Sci. Soc. China 7: 203. 1932; Cuillaum., Journ. Arn. Arb. 13: 27. 1932; Iucke, Tron. Woods 31: 20--21. 1932; Record, Trop. Woods 31: 23--29. 1932; Chiov., Fl. Somala 2: 365. 1932; Degener, Fl. Hawaii [1: 36] 3: 315: Vitex: Trif. Ova.t. 1232; Iill, Ind. lew. Suppl. 3: 249. 1933; Horticulture, ser. 2, Il: 290. 1933; lak., Gensyoku Yagai-Shokubutsu [Nature Col. ifild P1.] 4: 300. 1933; Terasaid, IIippon Shokubutsu Zufu [Jap. Bot. Illustr. Alburn] 712 \& 1225. 1933; Degener, Fl. Ilawaii. fig. 712. 1933; Nrooklyn Lot. Gurd. Record 22: 7. 1933; Nanehina, I. icrones. 314. 1933; Ducke, Arquiv. Jard. Eot. liio cle Janeiro 6: 33--39. 1933; Denthall, Trees Calcutta 356. 1733; Ishidoya, Chines. Drogen 1: 100. 1933; Narshall, Trees Trin. \& Tob. 77. 3.931.; Iasan., FI. \&. Geo. Yakus. 333. 1934; Noldenke, Phytologia 1: 101-10\%. 1934; Le Cointe, A Amaz. Eras. III Arv. e Pl. Uteis 269 \& 429. 1931.; Hand.-Waz., Act. Hort. Gothenb. 9: 67--68. 1234; Teuscher, Journ. New York Bot. Gard. 35: 157. 1934; J. A. llarris, Physico-chem. Prop. Plant Saps 50. 1931/; Yenko : al., Philipo. Journ. Sci. Bot. 55 (1): pl. 7, fig. 2. 1931; Crevost \& pstelot, Irull. Econom. Incio-chine 37: 1292--1295. 1934; Chiov., Racc. Bot. Niss. Consol. Kenya 99. 1935; Christoph., Bishop lus. Bull. 123: 192. 1935; lolfino, Trab. Inst. Bot. \& Farm. 53: 53 and 5l.: 79. 1935; E. I. lerr., Trans. Am. Phil. Soc., new ser., $2 L_{1}(2): 33 / 1-335$. 1935; Dop in Lecomte, Fl. Gén. Indochine 4 : 31]--3/43. 1935; L. H. \&. E. Z. Bailey, Hortus, rev. ed., 639. 1935; Nakai, Honda, Satake, : Kitagawa, Ind. Fl. Jehol. 4 (4): 1.1. 1936; Wolcott \& Otero, Journ. Agr. Univ. Puerto Pico 20: 133, 3.37, 300, 467, \& 626. 1936; H. C. Sampson, Dull. Lisc. Ins. Kew, addit. ser., 12: 175. 1936; Arthur \& Cummins, Philipp. Journ. Sci. Bot. 6́l: 479. 1936; Schaffner, Ohio Journ. Sci. 36: 202 . 1336; Kanehira, Formos. Trees, ed.2, 653, fir. 509. 1936; Degener, P1. llawaii. 315: Vitox: Trif.: Simp. 1036; Iland.-l'azz., Sumb. Sin. 7: 906. 1936; "oldenke, Revist. Sudam. Zot. 5: 2--3. 1.937; Irundell, Carnegie Inst. Wash. Publ. 478: 38, 39, 75, 96, 136, 11.3, 183, 191--191, \& 203. 1937; Herter, covist. Sudem. Lot. It: 137. 1937; H. S. Narshall, Journ. Soc. Jiblios. Nat. Iist. I: 69-72. 1937; F. C. Hochne, Dot. \& A Tr. Dras. Sec. 16: 24.3 \& 357. 1937; :olcenke, Phytoloria 1: 232. 1937; Dlumea 2: 262. 1937; Nerr. ¿ Jetcalf, Lingnan Sci. Journ. 16: 399. 1937; nill, Ind. Fer. Suppl. 9: 297--298. 1938; Fletcher, Kert Bull. 1933: L32--436. 1333; Ducke, Anais de Prim. Reun. Sul-Amer. Dot. 1: 237 \& 3: 393. 1933; Ohvi, Acta Phytotax. ¿ Geobot. Kyoto 7: 29. 1933; D. D. Nerr. \& falker, Bibl. Eastern As. Bot. 382. 1933; I. I. Bailey, " an Cult. P1. [repr. 2], 632 \& 849. 1933; Basu, Ind. Iedic. PI. 3: fir. 2499. 1939; Elm., Leafl. Philipp. Bot. 10: 3793. 1939; Rehd., Journ. Arn. Arb. 20: 1:15--428. 1939; Fedde, Bot. Jihresber. 59 (2): 417. 1939; Herter, Revist, Sudam. Bot. 6: 97. 1939; lierter, Beih. Bot. Centralbl. 59: 275. 1939; Humbert, Not. Syst. 8: 22--2L. 1939; Volcienke, Annot. List 109. 1939; Pittier, Supl. Plant. Usual. Venez. 5/1--55. 1939; Corner, 
Gard. Bull. Straits Settl. 10: 257--258. 1939; loldenke, Am. vidl. Nat. 24: 753--754. 1940; Volcenke, Trop. Woods 64: 29-38. 1940; Rehd., Ian. Cult. Trees, ed. 2, 305, 902, \& 994. 1940; Yuncker, Ficld lius. Publ. Bot. 9: 330. 1940; Woldenke, Prelim. Alph. List Invalid Names 6, 29, 33, \& 50--52. 1940; Gates, Fl. Yans. 191. I9LO; Noldenke, Phytologia 1: 4/.0. 1940; Nak., IIl. F1. Nipp. 186. 19L0; Kanehira, Formos. Trees, ed. 2, fig. 558. 19l.10; Yoldenke, Phytologia 1: $484_{4}-490$ and 2: 29--31. 194 1 ; Torsdell, Ind. Lond. Suppl. 2: 500--501 \& 579. 19lil; Hoehne, Kuhlmann, \& Handro, O Jard. Bot. São Paulo 578. 194l; L. H. Bailey, Jan. Cult. PI. [repr. 3], 632 \& 849. 1941; 0. B. Nill., Tydskrif van Suid-nfric. Bosbouver. 6: 93 \& 95. 1941; Indic. Taxon. Ass. Sudam. Fitotax. 1 (2): 3. 194l; Ii . Kuhlmann, Inst. zot. Observ. Ger. Contrib. 3: 40 \& 46, 4: 16, and 5: 19 \& viii. 1942; Van Velle, Journ. New York Bot. Gard. 43: 36, 37, \& 43. 1942; Yodge, Journ. Ijew York Bot. Gard. 43: 198. 1942; Hottes, Book of Shrubs 403--405. 1942; Pittier, La lesa Guanipa 56. 1942; loldenk in A. C. Sm., Sargentia 1: 115. 1942; Kanehira \& Hütusima, Jot. lag. Tokyo 56: 115--116. 1942; Contrib. Univ. Nich. Icrb. 3: 61. 1942; Lundell, Chron. Bot. 7: 170. 1942; Centry, Carnegie Inst. Wash. Publ. 527 [Rio llayo Pl.] : 33, 37, 42, 45, $64,66,223,224_{4}, 2: 306$. 1942; F. Miranda, Anal. Inst. Biol. Vex. 13: 450. 1942; H. F. Naclillan, Trop. Plant. \& Gard., ed. 5, 197, $2.14,216,217$, \& 366.1943 ; D. Fairchild, Gard. Isls. Great East 65. 1943; Y. llatsum., Amatores Herbarii 10: 54. 1943; Egler, Caribb. Forester 5: 14. 1943; Van Viclle, Shrubs \& Trees Small Place 54, 55, \& 177. 1943; Yuncker, Bishop ius. Bull. 178: 102. 1343; Parham, Fiji Native P1. 42. 1943; G. T. Hastings, Trees Santa lonica 105. 1944; Noreno Bello, liedic. Homeopat. l'ex. I: 1)--25. 1944; L. H. Bailey, Nan. CuIt. PI. [repr. 4], 632 \& 349. $19 L_{1}$; Quint, Govt. French Equat. Afr. Forest. Dept. Notice 4. 19l.4; Skottsb., Neddel. Goteb. Bot. Tradg. 15: 435. 1944; Le Cointe, O Istado do Para 212--213, 217, 231, \& 241. 1945; E. D. lierr., Pl. Life Pacific Torld 33, 37, 39, 42, 46, 47, 227, 228, 274, \& 282, fig. 46. 1945; Van Steenis, Science \& Scientists Neth. Ind. 399. 191,5; Darlington \& Janaki Ammal, Chromosome Atlas 271. 1945; :I. C. Leavenworth, Am. 1idl. Nat. 36: 146, 147, \& 137 . 1946; Gregory \& Vélez, Jaribb. Forester 7: 16, 20, 22, \& 33. 1946; Lombardo, F1. Arb. Urug. 97 \& 212. 1946; Irmão Augusto, Fl. Rio Grande do Sul 23]. 32 236. 19l.6; F. C. Hoehne, Frut. Indig. 77 \& 79, pl. 32, fiq. 1. 1946; Beard, Caribb. Forester 7: 41, 50, \& 56. 19l,6; Ienninger, Introduct. Offer Flower. Tree Coll. [1]. 19l,6; Razi, Journ. Iysore Univ. 7 (4): 64. 1946; I. D. Kerr., chron. Bot. 10: 311. 1946; lenninger, 1947 jat. Flow. frees $24-$ 25. 1.946; A. P. Benthall, Trees Calcutta 355--357. 1946; Daniel, Verb. Central Antioq. 7. 1947; Hill \& Salisb., Ind. Kew. Suppl. 10: 244. 1947; Lombardo, F1. Arb. is Arbores. Urug. 137--183. 191.7; Terrac., Trav. Lab. Nat. Ied. 33 (3): 101. 1947; Neal, Pacific Sci. 1: 244. 1247; Holdridge \& al., Forests West \& Cent. Jcuador 67. 1947; Robyns, Fl. Snerm. Parc Nat. Albert 2: 140Ili1. 1947; P'ei, Bot. Buill. Acac. Sin. 1: L--5. 1947; Rehd., Journ. Arn. Arb. 28: 253. 1947; Kuhlmann is Ituhn, Pl. Distr. 
Ibiti 117 \& 132. 1947; F. C. Hoehne, Relat. Anual Inst. Bot. Sto Paulo $44: 87$. 1947; Stumpp \& walter, Seed Annual for 1948: 26. 1948 ; Naunsell van Rensselaer, Trees Santa Barbara, rev. ed., 154 \& 191. 19433; F. R. Irvine, Journ. New York Bot. Gard. 49: 233. 19l43; New York Herald Trib., sect. 5, p. 17. June 27, 1948; Noldenke, Phytologia 2: 163 \&: 477. 1943; Reko, Bull. Soc. Bot. ?ex. 6: 24. 19l13; II. N. 2: A. L. Voldenke, PI. I,ife 2: 13, 21-24, $32,36,42--44,46,43--57,59-72,74-76,273--90.1943$; Gorrie, Geogr. Review 33: 36, fig. 18. 1943\%; Hara, Enum. Sperm. Jap. 1: 190--191. 1943; Beltrán, Cat. Sem. Hort. Bot. Univ. Valentin. 1943: 26. 1948; $\pi$. L. Phillips, Cat. Pl. Fairchild Trop. Gard. 41, 46, \& 47. 1949; Occhioni, Lilloa 17: 435. 191.9; Acosta Solis, Publ. Dept. Forest. Ecuador 7: 39. 1949; Rehd., Bibl. Cult. Trees \& Shrubs 534--535. 1949; Noldenke, Phytologia 3: 120 2. 173. 1949; H. N. \& A. L. loldenke, Anal. Inst. Biol. lex. 20: 14--15. 1949; Pickel, Piso e liarçrave Bot, Bras. 87. 1949; Guillaum., Bull. lius. Nat. Hist. Nat. Paris, sér. 2; 21: 261. 1949; Fosberg, Pacific Sci. 3: 339. 1949; Bruno \& d'Urso, Giard. Bot. Colon. Semina Anni 1949: 29. 19l,9; Nenninger, Evergr. Trees Street P1. [3] \& [7--8] . 1949; loldenke, Phytologia 3: 283, 284, 294, 295, 378, 379, \& 381. 1950; Razi, Journ. lysore Univ. II (2): 54. 1950; Langman, Select. Guide lex. Flow. Pl. 453 (mss.). 1950; Natuda, Am. Nidl. Nat. W4: 576. 1950; P. Henderson, Autumn Planting Guide 17. 1950; Stumpp \& Walter, 1950 Garden Annual 81. 1950; licEacharn, List Seeds Villa Taranta Gard. 8: 30. 1950; Aubrev., Fl. Forest. Soudano-Guin. 502. 1950; Kenninger, Winter 1950 Seed list n.p. 1950; l'enninger 1950-1951 Offer. 300 Diff. Flow. Trop. Trees [4]. 1950; Kelly Bros., 1951 Garden Book 45. 1951; Shreve \& ifiggins, Carnegie Inst. Wash. Publ. 591: 39 \& 94. 1951; Noldenke, Phytologia 3: 428-443, 454, 459--463, 463, \& 436--190. 1951; Rambo, Anais Bot. Herb. Barbosa Rod. 3: 72 \& 83. 1951; Noldenke, Am. Journ. Bot. 38: 327. 1951; 1. Pal, Journ. Indian Bot. Soc. 30: 59-74. 1951; E. A. Bruce in Bruce \& al., Dothalia 6: 237--233. 1951; New York Bot. Gard. Exchange List 1952: 4. 1951; Ciferri, 1ycopath. S lycol. Appl. 6: 19-27. 1951; loldenke, Phytologia 4: 53-65, 68, \& 70--33. 1352; Nazi, Poona Univ. Journ. I (2): 47. 1952; Gleason, New Britton \& $\mathrm{Br}$. Ill. Fl. 3: 133--139. 1952; Razi \& Govincu, Journ. iysore Univ. 12 (9): 104. 1952; F. Miranda, Veret. Chiapas 1: 99. 1952; A. C. Joshi, Zjol. Abstr. 26: 2293. 1952; Zohary, Palest. Journ. Lot., Jerus. ser., 5: 227. 1952; Biol. Abstr. 26: 382, 1746, \& 3351. 1952; Santapau, Anal. Bot. Cavanilles 11: 30. 1952; Santapau, Pl. Saurashtra 31. 1953; F. R. Irvine, Lejeunia 16: 40. 1953; Keay, Lejounia 16: 23. 1953; liew York Herald Trib., sec. 4, p. 16. August 23, 1953; loldenke, Phytologia 4: 134, 199, 2: 293--295. 1953; Roig y l..esa, Dicc. Bot. 1: 708, 327-329 and 2: 695--696, 825, \&. 1115. 1953; F. liranda, Veret. Chiapas 2: 263, 303, 391, \& 392. 1953; Wild., Vict. Falis llandb. 131 \& 153.1953 ; lenninger, Cat. Flow. Trop. Trees 16. 1953; Salisb., Ind. Kew. Suppl. 11: 265. 1953; Brenan, Nem. New York Bot. Gard. 9: 33. 1954; Wild, South. Rhodes. Bot. Dict. 137--133. 1954; R. B. Vivlie, Am. Journ. Bot. 41: 136--137. 1954; Reitz, sellowia 6: 249 s: 257. 
1954; Rambo, Sellowia 6: 60, 67, \& 153. 1954; De Laszlo \&c Henshaw, Science 119: 630. 1954; holdenke, Phytologia 5: 20. 1954; Ducke \& Black, Bol. Téc. Inst. Agron. Norte 29: 24 \& 33 . 1954; E. H. Walker, Import. Trees Ryukyu Isls. 235--236, fig. 135 . 1954; Kenninger, 1955 Price List n.p. 1954; Nullenders, Nebbia 11: 509. 1955; Biol. Abstr. 27: 3742 \& 3768. 1955; Noldenke, Phytologia 5: 142--176, 186--224, 257--280, \& 293--336. 1955; Angely, Gazeta do Povo Curitiba 37 (no. 10698): 5. December 8, 1955; lenninger, 1956 Price List [9]. 1955; Van Steenis, Fl. lales. Bull. 12: 474 . 1956.

Additional excluded species: Vitex grandiflora Turcz. = Arrabidaea candicans (Rich.) DC.

VITEX ACUNINATA $R$. Br.

Additional citations: AUSTrALIA: ?ueensland: A. Cunningham $256(\mathrm{~N}, \mathrm{~N})$.

\section{VITEX AGELAEIFOLIA Yildbr.}

This species, as accepted by Piepor in 1923, is not the same as the Vitex agelaeifolia ildbr., iiss. Irgebn. Zent. Afr. Exped. 1910/11, 2: 30, hyponm (1322). The latter is apparently a synonym of $\mathrm{V}$. phaseolifolia :'ildbr.

\section{VITEX AGNUS-CASTUS L.}

Adclitional literature: P. Fenderson, Handh. 21., new ec., 482. 1910; Russell, Dean, \&: Vauohan, Vevster's Imperial Dict. 1373. 1910--1911; Juncll, Symb. Bot. Upsal. 4: 94. 1934; Koldenke, Phytologia 5: 161--176 \& 136--139. 1955.

Additional synonymy: Vitex arguacustos L., in herb.

The economic uses enumerated in these notes under $\mathrm{V}$. necundo apply also to the present species. An additional common name recorded for the species is "liarrow-leaved Purple Chaste-tree". (Z).

Additional citations: CULTIVATED: Argentina: Ruiz Leal 13913

VITEX AGNUS-CASTUS $f$. ALBA (West.) Rehd.

An additional common name recorded for this form is "Narrowleaved "White Chaste-tree".

VITEX AGNUS-CASTUS $f$. LATIFOLIA (1ill.) iehd.

Additional common names for this form are "Broad-leaved Purple Chaste-tree" (for the purple-flowered type) and "Broad-leaved White Chaste-tree" (for the white-flowered type).

Additional citations: CULIIVATED: New York: H. No loldenke 21251 ( $\mathrm{Z}$.

VITEX AJUGAEFLORA DOP

Additional literature: Dop, Trav. Lab. For. Toulouse 1 (1): pl. 4. 1928; \%orsdell, Inci. Iond. Suppl. 2: 500. 19/11; :oldenke, Phytoloria 5: 126--197. 1955.

Illustrations: Dop, Trav. Lab. For. Toulouse I (I): pl. 4. 1923. 


\section{VITEX ALTISSIMA L. $f$.}

Additional literature: The references given by me in Phytologia 5: 200--201 (1955) under "Vitex altissima var. alata" should be transfurred here, and add: Wall., Numer. List [48], nos. 1752 S. 1755. 1329; Jacks., Ind. Kew. 2: 1213. 1395; Bakh. 2. Lam, Bull. Jard. Bot. Buj.tenz., ser. 3, 4 (2): 285. 1922; lenninger, 1956 Price List [9]. 1955; loldenke, Phytologia 5: 197--202. 1955.

Additional synonymy: The synonyms listed by me in Phytologia 5: 20l (1955) under "Vitex altissima var. alata" should be transferred here.

Santapau informs me that the specimens with broadly alate petioles, hitherto regarded as representing a variety of this species, actually are alvays from immature trees or from nonflowering branches of mature trees. On his collections no. 13604, 13605, and 13606, cited below -- all of which exhibit ron-alate petioles -- he states "Tree ca. $30 \mathrm{ft}$. high; flrs. very similar in colour and structure to $\mathrm{V}$. negundo; lower leaves with winged petiole, etc. as No. 13577; higher ones simply trifoliate." This observation has confirmed a long-standing suspicion of my own to the same effect. Practically all flomering specimens I have seen have had non-alate or practically non-alate petioles, while the specimens with very broadly alate petioles selcom, if ever, included flowering branchlets. For instance, Halloer: 2 liccann 34407, 344.03, and 34424, Jlatter 23419, Santapau 17735 and 13577 , Ierb. Fort. Bot. Borgor. IV.A. d4, XI. K. . XI.K.7a, and XII.V.VI.23, Koni 77 , Royon B?, and Voirt s.n., all have alate petioles and all are sterile (flowerless). On the other hand, Santapau 13604, 13605, 13606, 13633, 13639, 31atter 23399, J. Fernandez 1245 and s.n., Acland 976, J. Jernandez 24.53, and the specimens cited on page 200 under "Vitex altissima", almost all are in anthesis or fruit and show non-alate petioles. The Wicht s.n. specimen at New York exhibits an inflorescence and also alate leaves, but the leaves are detached from the inflorescencebearing branchlet and may well have been collected from a lower part of the tree. The Ilerb. Hort. Bot. Bogor. XI.K.7, XI.K.7a, and XII.B.VI.28 collections all show extraordinarily lare leaves, with 5,6 , and 7 leaflets rospectively, and were probably taken from very young trees or from vigorous shoots.

Rev. Santapau also points out that IF the variety were to be accepted as valid, the correct accredition of the trinomial would be "(Heyne) Trimen" and not "(iiilld.) loldenke" as stated by me in Phytolocia 5: 200 (1955), since the latter is clearly a later homonym and is therefore invalid under the present Article 74 of the International ilules of Nomenclature.

The binomial "Vitex trifolia L." dated " 1753 " by me on page 197 of the above-mentioned work should actually be dated "1731".

Santapau has collected the species in open forests and in cversreen forests in Dombay, flowering and fruiting in I.ay. Fernandez found it flowering in "arch and April. Santapau conments that it is a large shrub or snall tree by roadsicies (in lear only, so doubtless immature) and that it is comon on higher 
ground near roadsides. Vidal found it flowering in larch in Laos and reports the comion name "khi hén".

Additional citations: The specimens cited by me in Phytologia 5: 202 (1955) under "Vitex altissima var. alata" shoula be transferred here. To them should be adcied: INDIA: Lombay: Acland 276 (Xa); Blatter 23/119 (Xa), 23399 (Xa); J. Fernancez 130 (Xa), $1245(\overline{\mathrm{Xa}}), 2453(\mathrm{Xa})$, s.n. [1.arch 1949] (Xa); Yallbore \& lcCann 34407 (Xa), $\frac{34103}{(X a), 34424}$ (Xa); Santapau 17795 (Xa), $\frac{13577}{1 \times a)}$

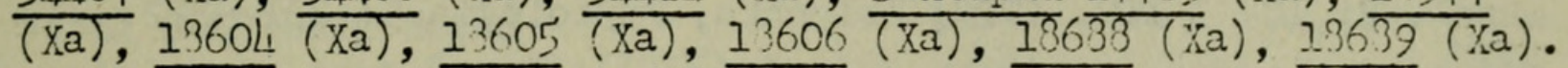
INIDOCLITI: Laos: Vidal $2327(2)$.

\section{VITEX AIBONIENSIS Curke}

Additional literature: Pieper in ingl., 3ot. Jahrb. Ei2, Beibl. 141 ["1l.2"]: 50, 63, 2 31, pl. 11. 1923; Poldenko, Phytologia 5: 204--206. 1955 .

Illustrations: Pieper in ingl., zot. Jahrb. 62, Jeibl. 1lil ["1) $1_{+2 "]}$ : p1. 11. 1923 .

\section{VITEX ANGOLENSIS Gurke}

The Iaum 298 collection cited by Pieper as this species is cited by Gurke in Daum, Kunene-Sambesi isped. 350 (1903), apparently erroneously, as $\mathrm{V}$. mechorii Gurke.

VITEX BARBATA Planch.

Additional literature: Pieper in En l., Bot. Jahrb. 6́2, Beibl. $1 / 11[" 1 / 42 "]: 48,61$, \& $31, \mathrm{pl}$. 10. 1928; Worsdell, Ind. Lond. Suppl. 2: 500. 19141; Noldenke, Phytologia 5: 209. 1255.

Illustrations: Pieper in Ingl., Bot. Jahrb. 62, Beibl. 1/!1 ["142"]: pl. 10. 1928 .

\section{VITEX BENTHANIANA Domin}

Additional literature: Domin, Bibl. Bot. $22(39-6): 1.114$ \&: 1117, fig.182. 1923; worsdell, Ind. Lond. Suppl. 2: 500. 1941; Noldenke, Phytologia 5: 210--211. 1955.

VITEX BEQUAERTI DEVIII.

Additional literature: Delild., Contrib. Fl. Katanga I6/4. 192.; Pieper in Engl., Bot. Jahrb. 62, Beibl. 11,]. ["1/2"]: 60. 1928; Delild., Contrib. Stud. Fl. Katanga Suppl. 2: 101 \&: 10l. 1929; 1.olcenke, Phytologia 5: 211. 1955.

Deilildeman cites Quarre 1036 from Ferme oranat and says that the plant is a shrub 3--5 neters tall, srowing on temitaria. He says that i.t is very closely related to $\mathrm{V}$. Eiorgii joild., differing in the pubescence on the lower leaf-surfaces.

VITEX BOJLRI Schau.

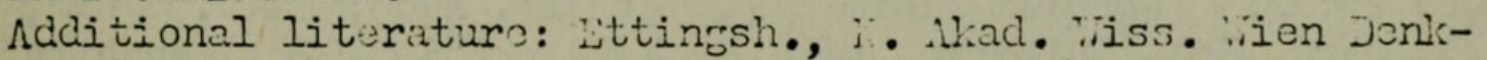
schr. 23: 219 [Fossile Flora Eilin 2: 32]. 1363; Piover in incl., Dot. Jahrb. 62, Jeibl. 14] ["142"] : 75, 78, ci 31, pl. 9. 1923; forsciell, Ind. Lond. suppl. 2: 500. 1241; 1oldenke, Plytologia 5: 215 . 1955 . 
Illustrations: Nieper in incl., Dot. Jahrb. 62, Deibl. I4l ["IL2"] : pl . 9.1923.

Acicitional synonym: Vitex boyeri schau, ex ittingsh., 1. . Akad. Wiss. ien. Denkschr. 23: 213 [Fossile tlora Hilin 2: 32], s.halm. 13663 .

\section{VITEX BUCHNERI Gurke}

Additional literature: Deilid., Contrib. Stud. Fl. Katanca supp]. 2: 107 \&: 109. 1929; loldenke, Phytologia 5: 221--222. 1355.

De.ildeman states that this species is closely rolated to $\mathrm{V}$. thorasi Deilic. and its variety kasaiensis De.ille.

VITEX CALOTHYRSA Sandir.

Additional literatire: Ducko s ilack, Bol. Téc. Inst. Ađron. :orte 29: 24. 175h; rolcionke, Phytologia 5: 223--224 \&259. 1955.

VITEX CANESCENS IUUR

Vidal records the additional vernacular name "sa nga" from Laos.

Additional citations: InDociII!A: Laos: Viclal 2031 (Z).

VITEX CAPITATA Vah

Aciditional synonyy: Vitex bicnonioices lunth ex uttinđsh., K. Mkad. Viss. Wion Denkschr. 20: 212 [Possilo II. Jilin 2: 31]. 2363 .

VITEX CIRYSOCARPA I'Ianch.

Chevalier cites is nos. 2754, 2756, 2765, 276́3, 2li3314, and s.n. from i'ronch Soucian.

VITEX CILIATA Pierre

Additional literature: "orsciell, Ind. Lond. suppl. 2: 500. 19!11; olconke, Phytolowia 5: 272. 1755'.

VITEX COCHIHCIIINENSIS DOP

Acicitional literature: Dop, Trav. Lab. For. Toulouse 1 (1): pl. 3. 1323; forsciell, Ind. Lond. Suppl. 2: 500. 1941; Loldenke, Phytojogia 5: 27L. 1955 .

VITEX COFASSUS Reinw.

Additional synonyny: Vitex punctata DC. ex Ettingsh., K. Akad. iiss. ijen Denkschr. 23: 219 [Fossile r'lora Dilin 2: 31]. 1363 . Vitex cofassus tyica H. J. Lam ex vorsdell, Ind. Lond. Suppl. 2: 500 . 1941.

Alditional literature: Attingsh., K. Akad. Wiss. \#ien Denkschr. 23: 219 [Fossile Hora Ei]in 2: 31] . 1863; Bakh. ? Lam, rull. Jard. Lot. Euitenz., sor. 3, I, (2): 235. 1922; ranohira, Fl. 'icrones. 34l!. 1933; Worsdell, Ind. Lond. Suppl. 2: 500. 19/11; Jolclenke, Phytolozia 5: 27l--27?. 1955.

Illustrations: Vanchira, 'l. 'icrones. 344. 1933. 
VITEX CONGOLENSIS Deirild. \& Th. Dur.

De:iildeman cites also De Giorgi 486 and 507, Boone 17, Ghesquière s.n., and Vanderyst 9666,10009 , and $1007 \overline{3}$ from the $\overline{\mathrm{Bel}}:-$ ian Congo and records the additional vernacular names "aanion", "konguluneme", "lifangelu", and "mundjuga". De Giorgi states that "bois pour la fabrication des gongs", "perches pour construction", and "grosses racines pour fabriquer des chaises".

\section{VITEX CUSPIDATA Hiern}

In Phytologia 5: 307 (1955) I cite Deilild., Plant. Bequaert. 5: 9--10 as "1932". It should be dated "1929". The dates of pullication of the parts of this volume are as follows: pp. 1--160 (october 1929), pp. 161--240 (Fobruary 1931), pp. 24l--352 (July 1931), pp. 353--L76 (Kay 1932), and pp. i-xiii \& 477--L96 (Jecember 1932).

Deilildeman observes "i.. Pieper fait observer avec raison qu'il est difficile, dans les conditions actuclles, de savoir exactement cequ'il en est de cette espèce. ilous sormes de son avis '''autant jlus que nous n'avons peu comparer des documents que nous nossècions, et qui ont été déterminés par le Dr. Guerke lui-même, avex le type de l'Ançola. Nous cioutons cependant un peu du rapprochement des plantes de Dupuis du groupe 'Elonfatac' car les calices florifères peu ajrès la chute à la corolle ne montrent pas le caractère: 'Bluten mit grosses meistregelmässiçer Kelkzthnen" ni "Tucht oft mit Stachelspitze". Dans la plante du :ayombe le calj.ce nesure à peine 1,5 mun. cle long, les cortos ì reine $0,5 \mathrm{~mm}$, donc relativement peu visible."

VITEX CYIOSA Bert.

Additional literature: Angely, Gazeta do Povo, Curitiva, 37: no. 10693, p. 5. December 3, 1955; Nolderke, Phytoloria 5: 307-313. 1355 .

Additional citations: COLONIA: Vagdalena: Romero Castaffeda 1029 (2). BRAZIL: Laranhao: Uurça Pires 2 Black 1532a (II). .inas

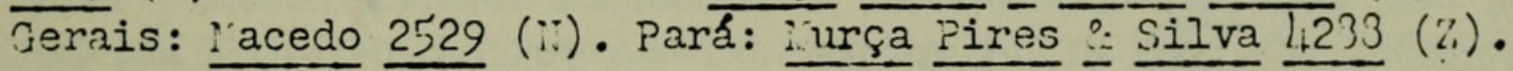

VITEX DIVARICATA Sw.

Additional literature: Forsdell, Ind. Iona. Juppl. 2: 500. 13L1; :oldenke, Phytolocia 5: 315-313. 1955.

Illustrations: i. C. "arshall, Trees Trin. i lob. 77. 1934.

VITEX DONIANA Sweet

Additional literature: R. L. Yates, Journ. Roy. Iort. Soc. Lond. 46: 337. 1921; Bakh. ? Lam, Eull. Jurd. Lot. Luitenz., sśr.

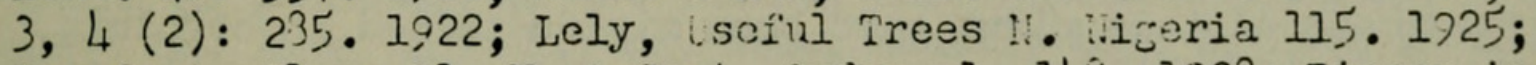
Gromfoot, Flow. Pl.e I1. 2i Cent. Suclan pl. 11.8. 1923; Pieper in En:l., Dot. Jahrb. 62, Beibl. 141 ["1.,2"]: 52, 64, 71--72, \& 32, pl. 11. 1923; De.iild., Plant. Bequaert. 5: 3--9. 1929; De.ilild., Contrib. Ltud. Fl. Katanga Suppl. 2: 101--103. 1929; Futchinson 2. Dalziel, Fl. \#. Trop. Afr. 2: 277. 1931; Worsdell, Ind. Lond. Sunn1. ?: 500. Jol:1; oldenke, phytologia 5: 322--326. 1955. 
Illustrations: R. I. Yates, Journ. Roy. Iiort. Joc . Lond. 46 : 337. 1921; Lely, iseful Irees N. Nigeria 115. 1925; Crowfoot, How. Pl. N. \& Cent. Sudan pl. 143. 1323; Pieper in Ingl., Bot. Jahrb. 62, Beibl. 1li] ["1L2"]: pl. 11. 1923; Hutchinson \& Dalziel, Fl. ir Trop. Afr. 2: 277. 1931.

quarre collected this species in flower in August. The V. divaricata Baker saic by me in my Prelim. Alph. List Invalid Names 50 (1940) to belong in the synonymy of $\mathrm{V}$. doniana actually is a synonym of $\mathrm{V}$. milnei Pieper. In Phytologia 5: 322 (1055) I cite je iild., Plant. Dequaert. 5: $3--9$ as having been published in "1932". These pares of that volume were actually issued in 1729.

V. coniana is said by collectors to be a tree 7--20 meters $\mathrm{talj}$, with a trunk 3--10 meters tall anc $20--80 \mathrm{~cm}$. in diameter; bark bromish-black or eray, f'riable, fissured, easily exfoliating; leâ-scars conspicuous; teminal buds large, brow, spherical, about $4 \mathrm{~mm}$. Iong and $3 \mathrm{~mm}$. wide, puosesent; branches cylindric or madranular, fray or bromish, snotted rith pinlrishwhite when fresh; twiess quacrangular, bromish-i)lack, spottec. with ilack and urown, pale-rreon torard the tips; petioles to 20 $\mathrm{cm}$. Ionc, urom or Ereen spotted with urom, compressed, canalicviate above, short-pubescent beneath; leaflet-blades short-nuvescent bereath, shiny above, sinuate-mar ined; secondarias issuine at anfles of $45-70^{\circ}$; calyx gray-brom; corolla vith 4 petals bromish on the exterior and white on the interior and tre fif'th petal bluish.

It is aaid to row on gray-black sand and on laterite, at 1200 meters altitude. Robyns states that it srows in fallery forests, is mymecophilous, and "bon bois de chaufface". "3equaert found? it on herbaceous savannas. Its mood is uscd by the natives to make tomtoms.

Chevalier cites his nos. 2757 and 2753 from the casamarice rerion of senegal, his nos. $12 \overline{366}$ anci $1 \longdiv { 4 7 9 9 }$ (the latter actually collected by Saille) from Trench Guinca, and kis nos. 16/4b, 2766, 2769 , and two s.n. collections from French soudan. Fe says that it attains a height of 17 meters and has yellowish corollas. De i.ldeman cites Dequert 62, 1/25, 1,306, and 7948, Blommaert 139, Claessens s.n., Delevoy $113, \overline{139}, 252,366$, and lili9, Dewevre 179, 1. Jumrent 1912, Iaurent - Laurent s.n., Ritschard 1512, Sapin s.n., Thomas 1327, Vandermej.ren s.n., Vanderyst 1, , , two s.n. collections, and Verschueren $\overline{K I}$ from Belcian Conco. He also records the adciitional vernacular names "kilikita", "furonco!" "mufuta", "mufutu", and "mukunke". The name "mufutu", howevor, is a eroun name, applied to 3 or 4 different kinds of trees.

Specimens of this plant have been misicle tified in hervaria as $V_{\bullet}$ ringoeti Dewild., a synonjm of $\underline{\mathrm{I}}$ madiensis var. milanjiensis (3ritten) Pi sper.

Additional citations: BLIGIAN COIGO: Quarre 205I ( $\mathrm{Nr}$, $\mathrm{Nr}$, Ir, ir, Dr).

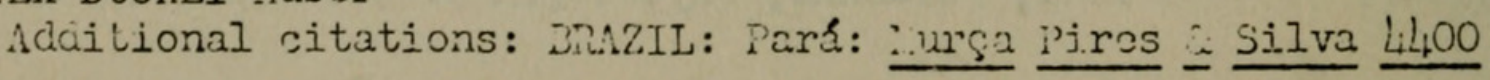


(N) .

VITEXX FLAVENS H.B.K.

Additional literature: Hook. \& Arn., Bot. Peechey Voy. 1: 305. 1838; Noldenke, Alph. List Invalid Names Suppl. 1: 28. 1947; H. N. \& A. L. Koldenke, Anal. Inst. Biol. Nexico 22: 15. 1949; Noldenke, Known Geogr. Distrib. Verbenac., [ed. 2], 62, 70, 74, 95, \& 201. 1949; Ducke \& Black, Bol. Téc. Inst. Agron. Norte 29: 38. 1954 . 1308.

Illustrations: Huber, Bol. Mus. Goeldi [Mus. Para.] 5: pl. 4.

Sirub or tree, to $20 \mathrm{~m}$. tall; branches tetragonal; branchlets rather stout, obtusely tetragonal, gray or brownish, flavescenttomentose or densely puberulent with brownish hairs, becoming more sparsely so or even glabrate in age, not noticeably lenticellate; twigs slender, rather short, tetragonal or compressedflattened, densely short-pubescent or puberulent with flavescent or fulvous hairs; nodes not annulate (or slightly annulate with a denser line of pubescence on young twigs); principal internodes $1--6.5 \mathrm{~cm}$. long; leaf-scars very large and corky, often greatly elevated on the branchlets; leaves decussate-opposite, 5-foliolate, very immature at time of anthesis; petioles slender, 2--12 $\mathrm{cm}$. long, convex beneath, flattened and canaliculate or sulcate above, densely short-pubescent with flavescent or fulvous pubescence, very slightly ampliate at the base, club-shaped at the apex; leaflets subequal or the two lowermost somewhat smaller than the central ones, all sessile or subsessile when immature but petiolulate when mature; petiolules slender, deeply canaliculate, 2--12 mm. long, densely short-pubescent or velutinous-tomentellous with flavescent or fulvous hairs; leaflet-blades membranous, very dark-grcen above (brunnescent or nigrescent in drying), flavescent or fulvous beneath, the central one oblong or lanceolate-oblong, varying to narrow-elliptic, $4--10 \mathrm{~cm}$. long, $1.5--$ $3.7 \mathrm{~cm}$. wide, acute or short-acuminate at the apex (rarely obtuse), entire, acute at the base, rather lightly appressed-pubescent throughout above, very densely and softly short-pubescent or velutinous-tomentellous beneath, the pubescence decidedly flavescent or fulvous, the lateral ones similar in all respects except often smaller and less acuminate; midrib slender, flat above, prominent beneath; secondaries slender, 10--20 per side, arcuate-ascending, flat above, prominulent beneath, arcuately joined at the margins beneath; vein and veinlet reticulation sparse, obscure or indiscernible above, usually hidden by the pubescence beneath or the larger portions conspicuous by not being as pubescent as the lamina; inflorescence axillary, cymose, $3-8 \mathrm{~cm}$. long, $1.5--4.5 \mathrm{~cm}$. wide, usually half as long as the subtending petiole, often corymbiform, 1 to 4 times dichotomous, usually densely many-flowered, canescent- or flavescent-puberulent or short-pubescent throughout; peduncles slender, 0.7-4.5 $\mathrm{cm}$. long, flattened, rather densely puberulent or short-pubescent or even tomentose, slightly ampliate at the apex and annulate with a band of denser pubescence; cyme-branches flattened, pubes- 
cent and annulate like the peduncles; pedicels varying from obsolete on lateral flowers to $6 \mathrm{~mm}$. long on central ones; bractlets oblong, spatulate, or linear, 3--6 mm. long, sessile; prophylla linear or setaceous, about $1 \mathrm{~mm}$. long, densely shortpubescent; calyx campanulate, $2-3.5 \mathrm{~mm}$. long and wide, densely appressed-pubescent with short flavescent antrorse hairs, its rim rather deeply 5-dentate, the teeth ovate-triangular, acute or blunt at the apex, often recurved or reflexed, brunnescent on the inner surface; corolla hypocrateriform, varying from purple or lilac to blue, lavender-blue, or blue-violet, its tube broadly cylindric, about $5 \mathrm{~mm}$. long, densely short-pubescent on the outside, its limb 2-lipped, the 4 small lobes $2--3 \mathrm{~mm}$. long and obtuse, the lower lip greatly enlarged, lingulate, 6--7 m. long, crisped along the rounded margin; stamens and style exserted about $5 \mathrm{~mm}$. from the corolla-mouth; fruiting-calyx cupuliform, about $4 \mathrm{~mm}$. Iong and $5 \mathrm{~mm}$. viide, its rim deeply triangulartoothed; drupes fleshy, subglobose, about $5 \mathrm{~mm}$. long and wide.

The type of this rather videspread species was collected by Humboldt and Bonpland [Herb. Willdenow 1l710] probably somewhere in Peru. The type of $v$. rusbyi was collected by Henry Hurd Rusby and Francis ihittier Pennell (no. 1143) in a light forest on a rocky hill at a gorge, altitude 450 to 550 meters, Natagaima, Huila, Colombia, on August 12, 1917. The species apparently inhabits a vast area from Colombia, Ecuador, and Peru to Amazonian Brazil. A Barclay specimen at Kew is labeled "Central America" and may be from Panama. It has been collected in anthesis in Narch, Nay, July, September, and October, ascending to 550 meters altitude in Colombia. It inhabits hilly land, light forests, especially rocky hills, bluffs, gorges, damp ground in quebradas, and streamsides, often in loam soil. The wood is used in the construction of houses in Ecuador, where it is considered excellent for this purpose. It has been confused with the very similar V. cymosa Bert. and V. gigantea H.B.K., as well as with the unrelated V. schomburgkiana Schau. and "V. montevidensis Cham." Kunth in his original description says that it is related to $\mathrm{V}$. rufescens A. I. Juss. and "V. ferruginea Vahl". Pavon designated it as "Leucoxylon" and as "Vitex sp. nov.", and the printed labels on his collection say "Nueva spaña", probably in error. It is called "taruman" and "tamman tuira" in Brazil according to Huber, "acietuno" in Colombia, anc. "pechiche" in Ecuador. Ducke calls it "tarumá" and "mameira". Le Cointe in his 1945 publication, cited above, records the names "taruman-tuira", "tarumatuira", and "tamuma grande do campo", while in his 1934 work he records "taruma grande do campo", "mammeira", and "tarumá tuira"

Ducke in his 1932 publication says that on the campos of the lower Amazon where V. triflora Vahl and V. flavens grow side by side one often finds specimens that seem to be hybrids between the two, with intermediate characters. Specimens so labeled and seen by me have proved to be V. triflora var. kraatzii Huber.

The date of publication of the binomial here accepted for this species is often given in books as "1817" or "1819", but 
was actually 1818 according to Barnhart in the reference cited above.

Citations: COLOMBIA: Cundinamarca: Goudot s.n. [Santa Fé de Bogota] (Cb). Huila: H. L. Mason 13840 (W--20 47916$)$; Rusby \& Pennell 221 (G, N), I143 (G, N, W--1041627); S. G. Smith 12引1 (Ca-963210, W--2047572). Magdalena: Goudot s.n. [vallé de la Magdalein] (K, P). Tolima: Goudot s.n. [Ibagué] $(K, P)$. ECUADOR: Esmeraldas: Lehmann $7647(B, F-578234, K)$; Rose \& Rose 23488 (G, N, W--1022980). Guayas: André 4155 (K, K, K, N $)$; Barclay $2469(\mathrm{Bm})$; Eggers 14524 (B, B); Mille 19 (W--1420112); Preuss 1941 ( $B, B)$; Schimpff 353 (B, B, Cb, E--1081683); Sinclair s.n. [Guayaquil] $(\overline{K, K}, K, N)$ s.n. [Puna] (K); Spruce S.n. [Guayaquil] (K). Los Rios: Schimpff 325 (B, B, Cb, E--1087720). Province undetermined: André 1942 (K, N); Eggers $15302(\mathrm{~F}-143079)$. PERU: Loreto: Tessmann $3 2 \longdiv { 4 7 } ( \mathrm { B } , \mathrm { Cb } , \mathrm { S } ), 4492(\mathrm{~B}, \mathrm{~B}, \mathrm{Cb}), 4587$ (B). Province undetermined: Humboldt \& Bonpland s.n. [Herb. Willdenow 11710; Macbride photos 3949[] (F--1038373--photo of type, Kr--photo of type, N--photo of type, N--photo of type, P-type, Z--photo of type); Pavon s.n. [Nueva Espafia] (Cb, E--photo, N--photo, Z--photo). BRAzIL: Amazonas: Ule 6163 (B, Cb, K, Le). Maranhåo: Lisboâ 2473 (Bm, Cb, P, W-1040300). Pará: Ducke 3699 $(\mathrm{Cb}, \mathrm{Cb})$; Huber $1630(\mathrm{Cb})$. State undetermined: Collector undesignated s.n. [Brazil] (P, P). I,OCALITY OF COLIECTION UNDETERMINED: Barclay s.n. [Central America] (K).

VITEX FLORIDULA Duchass. \& Walp, in Walp., Ann. Bot. Syst. 3: 240.1852.

Literature: Walp., Ann. Bot. Syst. 3: 240. 1852; Noldenke, Geogr. Distrib. Avicenn. 18. 1939; Moldenke, Known Geogr. Distrib. Verbenac., [ed. 1], 24 \& 103 (1942) and [ed. 2], 41 \& 201. 1949.

Tree, to $20 \mathrm{~m}$. tall; trunk rough, shaggy; wood very hard; crown low, rounded; branches and branchlets medium-slender, light-gray or whitish, obtusely tetragonal, minutely puberulent, becoming glabrate in age, rather corky, densely lenticellate; twigs short, more densely puberulent with grayish hairs; nodes not annulate, usually not ampliate nor flattened; principal internodes to $11 \mathrm{~cm}$. long, usually abbreviated to less than $1 \mathrm{~cm}$. on the branchlets and twigs; leaves decussate-opposite, developed after the flowers, 3-foliolate; petioles slender, $2.5--7 \mathrm{~cm}$. long, flattened above but not canaliculate nor margined, slightly ampliate at the base, very minutely and obscurely puberulent or glabrate; petiolules slender, $5--11 \mathrm{~mm}$. long, canaliculatemargined, very minutely puberul nt, the central one more elongate than the lateral ones; leaflet-blades firm ly chartaceous and rather thick when mature, very nitidous on both surfaces, dark-green above, bright-green beneath, elliptic, $4--14.8 \mathrm{~cm}$. long, $2.2-8 \mathrm{~cm}$. wide, acute or short-acuminate at the apex, entire, usually slightly subrevolute along the margins when mature, glabrous or glabrate on both surfaces, the lateral ones exactly 
similar to the central one only smaller; midrib deeply impressed above (on mature leaves), prominent beneath; s econdaries slender, 8-15 per side, arcuate-ascending, rather deeply impressed above, prominulent beneath, indistinctly arcuate-joined near the margin; vein and veinlet reticulation delicate, rather abundant, obscure or indiscernible above, plane beneath; inflorescence axillary, developed before the leaves; corolla purple or light-violet.

The type of this species is a Duchassaing collection from Panama. Hlayes describes the species as "a large verbenaceous tree 50--60 feet high, with rough shaggy trunk of very hard wood and naked of leaves". A wood sample is seen on Pittier 3477 at Kew and in the United States National Herbarium. Pittier calls it a small tree with a low rounded crown. It grows in forests on dry limestone soil and along rivers, ascending from sealevel to 100 meters altitude, blooming in April and Nay. It has been collected in leaf in October (Pittier 4683). It has been misidentified as $\mathrm{V}$. masoniana Pittier. The Paul 28 distributed as V. floridula is actually Godmania aesculifolia (H.B.K.) Standl., while the Chickering 59, also so distributed, is Arrabidaea florida P. DC., both in the Bignoniaceae.

Citations: PANAMA: Canal Zone: Christopherson 153 (W--716472); Hayes 15 (Ed), s.n. [March 20, 1861] (K); G. Haynes $464(N, N)$; D. Jones 325 (W--1686111, W--1686112); Mason 10 (N--photo, W-71604l, Z--photo); P. White 89 (N). Panama: P. H. Allen 959 (E-$1121187, \mathrm{~N}, \mathrm{~S})$; Pittier 3477 (A, Bm, Cp, F- 468401, F-506337, G, K, N, W--678522, W-678523), 4683 (G, N, N--photo, W-679843, Z--photo ), $6585(\mathrm{~N}, \mathrm{~W}-716650), 6604$ (E--883828, F--506354, G, $\mathrm{W}-716667), \overline{6626}(\mathrm{Bm}, \mathrm{G}, \mathrm{N}, \mathrm{W}-7 \overline{16693})$.

VITEX FOSTERI C. H. Wright, Kew Bull. 1908: 437. 1908.

Literature: C. H. Wright, Kew Bull. 1908: 437. 1908; Pieper in Engl., Bot. Jahrb. 62, Beibl. 141 ["142"]: 50, 68, \& 81, pl. 10. 1928; Worsdell, Ind. Lond. Suppl. 2: 500. 19Ll; Moldenke, Known Geogr. Distrib. Verbenac., [ed. 1], 46, 47, \& 103. 1942; l.olcienke, Phytologia 2: 119. 1944; H. N. \& A. L. Noldenke, P1. Life 2: 60. 1948; Moldenke, Known Geogr. Distrib. Verbenac., [ed. 2], 111--113 \& 201.1949.

Illustrations: Pieper in Ingl., Bot. Jahrb. 62, Deibl. 141 ["1)

Leaves 5--7-foliolate; leaflet-blades short-acuminate, partially dentate, glabrous above; calyx-teeth mostly regular, 2.5--3 $\mathrm{mm}$. long; corolla with large downwardly bent lobes when mature and deeply split upper lip; ovary broadly elliptic, hairy anc often also glanduliferous, but the glands hidden by the erect pubescence; fruit often spine-tipped.

Pieper cites Foster 34 from Lagos, Nigeria, and Thompson 37 from Gold Coast. Common names recorded for the species are "akwakora-gyahini", "ibang", "koro koronta", "obuban", "ogi", and "õrì-ětà".

Citations: GUINEA: Thonning 265 ( $\mathrm{Cp}, \mathrm{N}-$-photo, Z--photo). 
VITEX FROESII Noldenke, Phytologia 1: 485--486. 1941.

Literature: Moldenke, Phytologia 1: 485--486. 1941; Noldenke, Knowm Geogr. Distrib. Verbenac., [ed. 1], 39 \&: 103. 1942; Moldenke, Phytologia 2: 119. 1944; H. N. \& A. L. Moldenke, Pl. Life 2: 60. 19L3; Moldenke, Known Geogr. Distrib. Verbenac., [ed. 2], $95 \& 201.1949$.

Tree, to $15 \mathrm{~m}$. tall; trunk to $13 \mathrm{~cm}$. in diameter; branchlets medium-stout, gray, obtusely tetragonal, glabrescent; young twigs stout, obtusely tetragonal, very densely villous-tomentose with long fulvous hairs; buds densely long-villous; nodes somewhat enlarged and ampliate, not annulate; principal internodes $2.5--8 \mathrm{~cm}$. long; leaves decussate-opposite, 3-foliolate; petioles stout, $4.5--11 \mathrm{~cm}$. long, very densely villous-tomentose with fulvous hairs similar to those on the twigs; petiolules absent; leaflet-blades subcoriaceous, sessile, broadly elliptic or obovate, lighter beneath, the central one $3--13.5 \mathrm{~cm}$. long, 5-$12.3 \mathrm{~cm}$. wide, rounded or very slightly cuspidate at the apex, entire, slightly undulate or sinuate, cuneate and symmetrical at the base, densely villous-velutinous on both surfaces, more conspicuously so beneath, with flavescent hairs; midrib stoutish, prominulous (except toward the apex) above, very prominent beneath; secondaries slender, 10-15 per side, ascending, not much arcuate (except toward the margins), close together, joined in many loops at the margins, very slightly impressed above, prominent beneath; veinlet reticulation abundant, slightly impressed above, prominulous beneath; lateral leaflets similar, practically the same size as the central one or slightly smaller, but usually asymnetric at the base or as mmetric throughout, often rounded or subtruncate at the base, or the outer half broadly rounded and the inner half cuneate at the base; inflorescence glomerate, sessile, bracteose, very densely long-villous with fulvous hairs; bracts numerous, lanceolate, $1.8--2.3 \mathrm{~cm}$. long and $2--5$ $\mathrm{mm}$. wide at the base, sessile, densely villous on the outer surface, concave from within, an opposite pair closely appressed to the base of the calyx and alternate with its lips; calyx tubular, about $1.8 \mathrm{~cm}$. long and $5 \mathrm{~mm}$. wide, distinctly 2-lipped, one lip 2-lobed at the apex, the other lip 3-lobed, the lobes 1--3 mm. long, slender, triangular-acuminate, the sinuses between the lips about $5 \mathrm{~mm}$. deep, in fruit greatly enlarged and splitting to the base, the 2 halves broadly ovate-elliptic, to $2.5 \mathrm{~cm}$. long and $1.7 \mathrm{~cm}$. wide, the lobes $5--7 \mathrm{~mm}$. long; corolla and fruit not known.

The type of this most remarkable species was collected by Ricardo de Lemos Froes (no. 11660) on high land in a high forest on terra firma along the Rio Pindare, Rapoza l'onção, liaranhão, Brazil, on December 15, 1937. He states that a vernacular name for the plant is "taruma da mata". It is known only from the original collection.

Citations: BRAZIL: I!aranhão: Frós 11660 (N--isotype, N--isotype, N--type).

VITEX GABUNENSIS Gurke in Engl., Bot. Jahrb. 18: 167. 1994. 
Literature: Gurke in Engl., Bot. Jahrb. 13: 167. 1394; J. G. Baker in Thiselt.-Dyer, Fl. Trop. Afr. 5: 327. 1900; Pieper in Engl., Bot. Jahrb. 62, Beibl. 14l ["142"]: 43, 56, \& 81. 1928; íoldenke, Known Geogr. Distrib. Verbenac., [ed. I], 48 \& 103 (1942) and [ed. 2], 114 \& 201. 1949.

Shrub, 1--l.3 m. tall; branchlets glabrous; leaves opposite, 5-foliolate; leaflet-blades moderately firm, distinctly stalked, oblong-cuneate, green and glabrous on both surfaces, entire, the central one $20--22.5 \mathrm{~cm}$. long and less than half as vide; cymes sparse, short-pedunculate; bracts often reduced; calyx cyathiform, gradually attenuate into the pedicel at base, its pubesconce appressed, glabrous within; corolla over $3 \mathrm{~mm}$. long, its tube longer than $11 / 2$ times the calyx length, the tip of the upper lip $1 / 5$ to $1 / 3$ the length of the tube; fruit globose, the size of a large pea; fruiting-calyx about $7 \mathrm{~mm}$. in diameter, its rim subentire.

The type of this species, and the only known collection, is Soyaux 163 from Sibange Farm, lunda, Gabun, in French Equatorial Africa.

VITEX GAMOSEPALA Griff., Notul. 4: 173. 1351.

Synonymy: Vitex gamosepala var. typica H. J. Lam, Verbenac. Walay. Arch. $\overline{210.1919 . ~ V i t e x}$ glossocalyx H. J. Lan, Bull. Jard. Bot. Buitenz., sér. 3, 3: 59, in not. 1921.

Literature: Griff., Iotul. 4: 173. 1351; Griff., Ic. Pl. Asiat. pl. 448, fig. 2. 1354; C. B. Clarke in Hook. f., Fl. Srit. Ind. 4: 538. 1385; King \& Gamble, Nat. Fl. Nalay Penins. 855-357. 1905; King \& Gamble, Journ. As. Soc. Beng. 74: 355--356. 1909; H. J. Lam, Verbenac. lialay. Arch. 209--211 \& 369. 1919; Ridl., Fl. Nal. Penins. 635--636. 1923; Fletcher, Kew Bull. 1938: 436. 1938; Moldenke, Suppl. List Common Names 6, 13, 17, 20, \& 21. 1940; Moldenke, Known Geogr. Distrib. Verbenac., [ed. 1], 60, 61, \& 103. 1942; Koldenke, Phytologia 2: 119. 1944; Holdenke, Know Geogr. Distrib. Verbenac., [ed. 2], 133--140 \& 201. 1949.

Illustrations: Griff., Ic. PI. Asiat. pl. 443, fig. 2. 1854.

lioderately sized tree, $4--8 \mathrm{~m}$. tall, usually with many stems; bark smooth, grayish; branchlets more or less tetragonal, minuteJy pubescent and glandulose; leaves 3-foliolate; petioles 4.5-$10 \mathrm{~cm}$. long, minutely pubescent and glandulose; petiolules $0.3--$ $2.5 \mathrm{~cm}$. long, minutely pubescent and glandulose; leaflet-blades chartaceous, ovate or ovate-lanceolate, $9--1.7 .5 \mathrm{~cm}$. long, $4--6.5$ $\mathrm{cm}$. wide, acuminate at the apex, acute or attenuate at the base, entire, glabrous on both surfaces except for the pubescent midrib, glandulose beneath, the lateral ones smaller in all respects; secondaries 5--7; cynes axillary, short-pedunculate, dichotomous, $1.3--4 \mathrm{~cm}$. long and wide; peduncles 2--10 mm. long; calyx-tube 2.5--3 mm. long, 2-lipped, the upper lip entire, $4 \mathrm{~mm}$. Iong, the lower lip deeply bifid, 2--2.5 mm. long, glabrous and very densely yellow-glandular trroughout; corolla-tube slender, $8--12 \mathrm{~mm}$. long, glabrous and very densely glandular (except the lowest 1 $\mathrm{mm}$.$) on the outer surface, glabrous within except for a ring of$ stiff antrorse hairs at the middle, the upper lip entire or 2- 
lobed, the lower lip 3-lobed; stamens inserted at about the middle of the corolla-tube; anthers reniform; ovary pubescent and glandulose; fruit drupaceous, globose, anout $4 \mathrm{~mm}$. long and wide, glabrous, brown-lenticellate, green when young, black when mature.

This species is said to be common in deciduous forests on rocky ground, at altitudes of 50 meters, in Siam. Common names recorded for it are "cooked rice leban", "lĕban nasi", "lěban pachat", "leech's Iĕban", "mak lek mak noi", "pĕlong", "sĕtulang", and "sulong chong". Lam's variety typica is based on Griffith 6065 and haingay 1202 from Malacca as cotypes -- the same collections as are cited for the species by Clarke. Kin \& Gamble cite in addition Scortechini $445 \& 1480$ and Kunstler s.n. [King's Collector 1841] from Perak, Curtis 2366 and Ridley 8546, 10213, \& 10479 from Selangor, and Ridley 2788 from Singapore.

Citations: THAILAND: Smitinand $\overline{1 / 48}$ [Herb. Roy. Forest Dept. 6822] (Z). MALAYA: Malacca: Griffith 6065 (N, N--photo, S, Ut-11513, 2--photo).

VITEX GAMOSEPAIA var. KUNSTLERI King \& Gamble, Journ. As. Soc. Beng. 74: 856--857. 1909.

Synonymy: Vitex acuminata Korth. ex H. J. Lam, Verbenac. Malay. Arch. 369, in syn. 1919 [not V. acuminata R. Br., 1810]. Vitex neglecta var. glabrior H. J. Lam in Lam \& Bakh., Bull. Jad. Bot. Buitenz., sér. 3, 3: 60. 1921. Vitex vestita var. neglecta f. glabrior H. J. Lam, Bull. Jard. Bot. Buitenz., sér. 3, 5: 176. 1922. Vitex vestita var. genuina $f$. glabrior Beumée, in herb.

Literature: King \& Gamble, Nat. Fl. Kalay Penins. 856--357. 1905; King \& Gamble, Journ. As. Soc. Beng. 74: 856. 1909; H. J. Lam, Verbenac. Nalay. Arch. 210--211 \& 369. 1919; H. J. Lam in Lam \& Bakh., Bull. Jard. Bot. Buitenz., sér. 3, 3: 60. 1921; H. J. Lam, Bulì. Jard. Bot. Buitenz., sér. 3, 5: 176. 1922; Rendle, Journ. Bot. 63: Suppl. 81. 1925; Moldenke, Known Geogr, Distrib. Verbenac., [ed. 1], 63, 65, \& 103 (1942) and [ed. 2], 143, 146, \& 201. 1949 .

This variety differs from the typical form of the species in having its petioles $2.5-5 \mathrm{~cm}$. long, the leaflets $5-7.5$ [--13?] $\mathrm{cm}$. long and $2.5--4 \mathrm{~cm}$. wide, the central petiolule about $1.3 \mathrm{~cm}$. long and the lateral ones about $6 \mathrm{~mm}$. long, the cymes about 1.3 $\mathrm{cm}$. long and wide, the peduncles about $2 \mathrm{~mm}$. long, the calyx about $2.5 \mathrm{~mm}$. long, sparsely glandular and sornewhat pubescent, the upper lip about $1.8 \mathrm{~mm}$. long and entire or 2-lobed, the lower lip about $1.25 \mathrm{~mm}$. long and bifid, and the corolla-tube about 1.2 $\mathrm{cm}$. long, densely glandulose, the upper lip shortly 2-lobed.

The plant is said to be a shrub, small tree, or large tree, with yellow, orange, or bright-orange corollas, and brown fruit which becomes black in age.

Cotypes of the variety are King's Collector 10605 from Perak and Rostado s.n. [Ridley 11982] from Trengganu. The type of $\mathrm{V}$. neglecta var. glabrior and the other polynomials based on it ap- 
pears to be Jacobson 2675 in the Buitenzorg herbarium. The variety has in the past been misidentified in herbaria as V. gamosepala Griff and $V$. vestita Wall. Common names recorded for it are "kajoe giak batae", "kajoe golom lisak", "kajoe lisak", and "kajoe pat ni lisak". Forbes 2685 is cited for this variety by Lam and by Rendle, but the Vienna University sheet of this number, examined by me, is not even verbenaceous. A case of transposed labels may be involved here.

Lam cites in addition Junghuhn 520, Beccari 768, and Korthals s.n. [Herb. Lugd.-Bat. 908266-750] from Sumatra and Winkler 2433 from Borneo.

The variety has been collected in anthesis in March and June and in fruit in August, at altitudes of from 100 to 250 meters.

Citations: SUMATRA: H. H. Bartlett 6919 (N); Boeea 7155 (S), 7532 (S), 7821 (S), $797 \bar{I}(\bar{S})$; Bunnemei jer 103 (Bz-25379, Bz-25677); H. O. Forbes 2771 (N, Vu); Jacobson 2675 (Bz-25382, N-photo, z--photo); Posthumus 702 (Bz--25395, Bz-25396, Bz--97184), 988 [77] (Bz--25392, Bz--25393, Bz--25394); Toesin 8 [Boschbouwproefst. BB.8131] (Bz--25380); Wahab 3 [Boschbouwproefst. BB. 8110] (Bz--25381); Yates $1183(\overline{\mathrm{Bz}-2} 5 \overline{413}, \mathrm{~N}), 2036(\mathrm{Bz}-24044$, $\mathrm{Bz}-24045, \mathrm{~N})$.

VITEX GAMOSEPAIA var. SCORTECHINII King \& Gamble, Journ. As. Soc. Beng. 74: 856. 1909 .

Literature: King \& Gamble, Mat. Fl. Malay Penins. 856. 1905; King \& Gamble, Journ. As. Soc. Beng. 74: 856. 1909; H. J. Lam, Verbenac. Níalay. Arch. 210. 1919; Rendle, Journ. Bot. 63: Suppl. 81. 1925; Moldenke, Known Geogr. Distrib. Verbenac., [ed. 1], 63 \& 103 (1942) and [ed. 2], 143 \& 201. 1949.

This variety differs from the typical form of the species in having its calyx $2 \mathrm{~mm}$. long, less densely glandulose, the upper lip about $1.8 \mathrm{~mm}$. long and entire, the lower lip about $0.65 \mathrm{~mm}$. long and 2-toothed, the lobes acute, and the corolla somewhat pubescent and less densely glandulose.

The variety is based on Forbes 3060 from Sumatra, collected at an altitude of 600 feet. King \& Gamble also cite Ridley 9725 and Wray 180, 992, and 1080 from Perak and Ridley 10096 from Negri Sembilan.

VITEX GARDNERIANA Schau. in A. DC., Prodr. 11: 687--688. 1847.

Synonymy: Vitex gardneriana Cham., in herb.

Literature: Schau. in A. DC., Proòr. 11: 687--688. 1847; Schau. in líart., Fl. Bras. 9:296. 1851; Noldenke, Alph. List Common Names 16. 1939; Moldenke, Geogr. Distrib. Avicenn. 27. 1939; Moldenke, Known Geogr. Distrib. Verbenac., [ed. 1], 39 \& 103. 1942; Noldenke, Phytologia 2: 119. 1944; H. N. \& A. L. Noldenke, P1. Life 2: 60. 1948; Noldenke, Known Geogr. Distrib. Verbenac., [ed. 2], 95 \& 201.1949.

Shrub or low spreading tree, to $4 \mathrm{~m}$. tall, often broader than high; branchlets slender, obtusely tetragonal, gray, subglabrate; 
twigs slender, rather elongate, gray-buff or browmish, obtusely tetragonal, densely short-pubescent throughout with grayishcanescent hairs, somewhat lenticellate; nodes annulate; principal internodes $0.7-6 \mathrm{~cm}$. long, mostly elongate; leaves decussateopposite, 1-foliolate, the joint in the petiole not obvious; petioles medium-slender, $12--15 \mathrm{~mm}$. long, densely short-puberulent with canescent or sordid-brownish hairs, convex beneath, flattened and canaliculate above, very slightly ampliate at the base, not noticeably jointed; blades firmly chartaceous or subcoriaceous, light- or dark-green on both suriaces or somewhat lighter beneath when immature, shiny above when mature, varving from lanceolate or obovate-lanceolate to oblong-elliptic, 6.5-$11.5 \mathrm{~cm}$. long, $1.8--3.4 \mathrm{~cm}$. wide, bluntly acute or obtuse at the apex, entire or obsoletely serrate, acute or obtuse at the base, sometimes slightly cuneately attenuate, very minutely and obscurely pulverulent-puberulent above (especially on the midrib), soon becoming glabrate and shiny, rather densely short-pubescent beneath with cinereous-canescent or sordid-brownish hairs, furfuraceous when young; midrib slender, rather deeply impressed above, very prominent beneath; secondaries slender, $8--11$ per side, arcuate-ascencing, flat or subimpressed above, very sharply prominent beneath, arcuately joined near the margins beneath; vein and veinlet reticulation abundant, flat or the larger parts subimpressed above, all parts conspicuously prominent beneath; inflorescence axillary, cymose, simple, rather sparse, 1.3--3.5 $\mathrm{cm}$. long, 1--2.5 cm. wide, usually once or twice dichotomous, 3$7-f l$ wered; peduncles slender, $1--1.5 \mathrm{~cm}$. long, somewhat flattened, slightly ampliate above, densely pubescent with canescent or yellowish hairs, often annulate with a band of larger and denser hairs at the apex; cyme-branches similar; pedicels obsolete or $1--2 \mathrm{~mm}$. long and densely pubescent like the peduncles and cymebranches; bracts and bractlets oblong-linear or oblanceolate, stipitate, to $1 \mathrm{~cm}$. long; prophylla linear, $1--3 \mathrm{~mm}$. long, densely canescent-pubescent; calyx campanulate, about $4 \mathrm{~mm}$. long and wide, densely white-pubescent, its rim 5-dentate, the teeth about $1 \mathrm{~mm}$. long, ovate, spreading, rather acute at the apex; corolla violet, hypocrateriform, its tube cylindric, slightly ampliate at the apex, glabrous within the calyx, white-lanate or tomentellous toward the apex above the calyx, the limb pulverulent-puberulent within, densely white-lanate or tomentellous on the outer surface, the upper and lateral lobes smaller, ovate, about $4 \mathrm{~mm}$. long and wide, obtuse, the large lower lip rotund, about $7 \mathrm{~mm}$. long and wide, its margins undulate-crisped; fruiting calyx subpatelliform, 2--3 mm. long, about $9 \mathrm{~mm}$. wide, whitetomentellous outside, its rim irregularly toothed; fruit drupaceous, oblong, about $10 \mathrm{~mm}$. long and $8 \mathrm{~mm}$. wide, nigrescent and hard in drying, glabrous, 2-sulcate toward the base.

This very distinctive species was based by Schauer on unnumbered G. Gardner and Houllet specimens from "circa Rio de Janeiro" It seems obvious, however, that the Gardner collections to which he refers are nos. 1107 and 1107bis which were collected in the state of Pernambuco, although the Conservatoire et Jardin Botan- 
iques, Geneva, specimen is inscribed "mont. d'Organ". The New York Botanical Garden snecimen bears a label reading "near Pernambuco". The Glaziou collections cited below bear labels in most herbaria reading "Rio de Janeiro", but were actually collected in the state of Espirito Santo according to Glaziou's own published report.

The species inhabits deserts of rock and sand, dry bushy, sandy, or rocky places, and the margins of streams, ascending to 300 meters altitude. It has been collected in anthesis from June to September and in November, and in fruit in August. Common names are "jaramataia" and "girimato". It has been confused with and distributed as Avicennia africana P. Beauv., Aegiphila sp., and even as the fern Nephrodium pohlianum Presl! Turczaninow states that Vitex erythrocarpa Salzm. is closely related to this species, but actually Salzmann's name is a synonym of Aegiphila lhotzkiana Cham.

Citations: BRAZIL: Alagoas: M. A. Chase 7808 (A, E--932723, F-568042, W--1232130). Ceará: Drouet 2389 (F-877984, F--948892, $\mathrm{G}, \mathrm{N}, \mathrm{S})$; Ducke $989(\mathrm{Bm}, \mathrm{Cb}, \mathrm{N}, \mathrm{P}, \mathrm{W}-1040229), 1156$ (Bm, P, W--

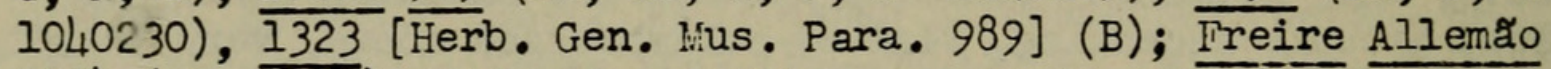
1174 (Ja--5971), 1179 (Ja--5972), s.n. [Herb. Rio de Janeiro 31774] (N), s.n. (Ja-44808). Espirito Santo: Glaziou 11322, in part $(\mathrm{K}), 11 \overline{323}$, in part $(\mathrm{B}, \mathrm{Cp}, \mathrm{P})$. Parahyba: Pickel $3951(\mathrm{~N})$.

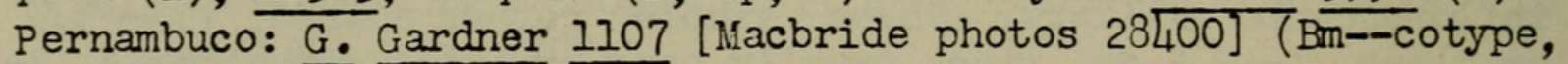
Bm--fruit of cotype, $\mathrm{Cb}-$-cotype, Ed--cotype, F--831263--photo of cotype, $\mathrm{K}$--cotype, $\mathrm{K}$--cotype, $\mathrm{Kr}$--photo of cotype, N--cotype, N-photo of cotype, P--cotype, P--cotype, S--cotype, V--cotype, W-1066494--cotype), 1107bis (K--cotype). Pio de Janeiro: Ioullet s.n. [along the Capibaribe, lioxoto, etc.] (Br--cotype).

VITEX GAUMERI Greem., Field kus. Publ. Bot. 2: 260--261. 1907.

Synonymy: Vitex pyramidata Millsp. apud Greenm., Field Kus. Publ. Bot. 2: $\overline{261}$, in syn. 1907 [not V. pyramidata B. L. Robinson, 1894]. Vitex Iongeracemosa Pittier, Contrib. U. S. Nat. Herb. 20: 486. 1922. Pekea pedunculata Schott ex Voldenke, Prelim. Alph. List Invalid Names 33, in syn. 1940. Vitex gaumerii Greenm. ex lioldenke, Prelim. Alph. Iist Invalid $\overline{\text { Names }}$ 50, in syn. 1940.

Literature: Millsp., Publ. Field Mus. Bot. 1: 317. 1896; Greenm., Publ. Field Mus. Bot. 2: 260--261. 1907; Pittier, Contrib. U. S. Nat. Herb. 20: 486. 1922; Record \& Mell, Timbers Trop. Am. 526--527. 1924; Standl., Publ. Field Mus. Bot. 3: 404 . 1930; Junell, Symb. Bot. Upsal. 4: 93--95, fig. 142 a \& b. 1934; Lundell, Carnegie Inst. Wash. Publ. 478: 38, 39, 75, 96, 136, 143, 183, 191--194, \& 203. 1937; Moldenke, Alph. List Conuon Names 4, 5, 10, 12, 17, 19, 21, 22, \& 33. 1939; Moldenke, Geogr. Distrib. Avicenn. 14--16. 1939; Moldenke, Carnegie Inst. Wash. Publ. 522: 208--210. 1940; Yuncker, Publ. Field Wus. Bot. 9 (4): 330. 1940; Moldenke, Supp1. List Common Names 24. 1940; Noldenke, Prelim. Alph. List Invalid Names 33 \& 50--52. 1940; Contrib. 
Univ. Nich. Herb. 8: 61. 1942; Lundell, Chron. Bot. 7: 170. 1942; Moldenke, Known Geogr. Distrib. Verbenac., [ed. 1], 19--21 \& 103. 1942; Noldenke, Alph. List Invalid Names 34 \& 53--55. 1942; Egler, Caribb. Forest. 5: 14. 1943; Moldenke, Phytologia 2: 119. 1944; H. N. \& A. L. Moldenke, PI. Life 2: 60. 19L8; Moldenke, Knowm Geogr. Distrib. Verbenac., [ed. 2], 33; 36, 37, \& 201. 1949; Matuda, Am. Midl. Nat. 44: 576. 1950. 1934.

Illustrations: Junell, Symb. Bot. Upsal. 4: fig. 142 a \& b.

Shrub or large tree, $7--30 \mathrm{~m}$. tall; trunk to $60 \mathrm{~cm}$. in diameter; crown spreading; branches and branchlets very stout and heavy, very medullose, obtusely tetragonal, often sulcate, gray or almost white, densely short-pubescent or puberulent with Erayish hairs (rarely becoming glabrate); twigs densely shortpubescent or puberulent with grayish, albidous, or flavescent hairs; nodes mostly distinctly annulate; leaves 5--7-foliolate; petioles slender or stout, 3--14.5 cm. long, flattened and canaliculate above, densely short-pubescent with albidous, cinereous, or sordid hairs; leaflets usually unequal in size, the 2 lowermost considerakly smaller than the central ones, all rather longpetiolulate on slender or stoutish densely puberulent or shortpubescent canaliculate and submargined petiolules, which are 2-$38 \mathrm{~mm}$. long, those of the 2 lowermost leaflets usually much shorter than those of the central ones; leaflet-blades thinchartaceous during anthesis, more firm and heavy in age, darkor dull-green above, usually much lighter or even albidous beneath, the central one elliptic, ovate-elliptic, or subobovate, $5--27 \mathrm{~cm}$. long, $1.8--12.5 \mathrm{~cm}$. wide, acute or acuminate at the apex, sometimes rather long-acuminate, entire, varying from obtuse, subcordate, or rounded to acute or short-acuminate at the base, densely or sparsely short-pubescent, strigillose, or puberulent above, densely matted-tomentulose, velutinous, or shortpubescent beneath with albidous, cinereous, or sordid-gray pubescence, varying to much more sparsely short-pubescent on watersprouts; inflorescence axillary, paniculate-thyrsoid, $8.5--30 \mathrm{~cm}$. long, 2--15 cm. wide, normally composed of 2 or 3 pairs of lateral paniculate branches, which are $4--13 \mathrm{~cm}$. long, each branch composed of 3-6 pairs of rather long-stipitate cymes, manyflowered, usually rather loose, densely canescent-puberulent or short-pubescent throughout; peduncles, rachis, and inflorescencebranches rather slender, often distinctly flattened, densely cinereous-puberulent or short-pubescent like the twigs and petioles, the pubescence often wearing off from the angles and exposing a nigrescent under-surface; peduncles $3.5--11.5 \mathrm{~cm}$. long; pedicels very slender or filiform, 1--3 mm. long, puberulent or short-pubescent; bracts few (or absent), caducous, simple, longstipitate, ovate, to $2.5 \mathrm{~cm}$. long, resembling the leaflets in puberulence; bractlets linear, $2--5 \mathrm{~mm}$. long, densely short-pubescent; prophylla minute, linear, about $1 \mathrm{~mm}$. long, densely short-pubescent; flowers pleasantly fragrant; calyx campanulate, 2.5--3 mm. long, canescent-puberulent or pubescent, subbilabiate, acutely 5-toothed, 3 teeth on the inferior and 2 on the upper 
lip, the middle inferior tooth broader and shorter than the rest; corolla varying from blue, bright-blue, sky-blue, lightblue, or deep-blue to lilac-blue, lilac, bluish-purple, purple, or bright-purple, sparsely evanescent-puberulent on the outside, barbellate at the insertion of the stamens and puberulent at the base of the inferior lip within, its tube $5--6 \mathrm{~mm}$. long, its limb bilabiate, the 2 posterior lobes small, subrotund, about 2 $\mathrm{mm}$. long and wide, reflexed, the 3 anterior lobes $5-6 \mathrm{~mm}$. long, spreading, the median lobe slightly pulverulent on the upper surface near its base; fruiting-calyx patelliform, 7--8 mm. wide, reflexed in age; fruit fleshy or hard, depressed-globose, $12--15 \mathrm{~mm}$. long and wide, smooth, yellow.

Lundell reports the vernacular Mayan names "yaxnic" and "yaaxnic" (meaning "blue flower") and describes the species as "generally a small to medium-sized tree, but sometimes reaching a diameter of $70 \mathrm{~cm}$. and a height of 20 meters; common in climax forest and secondary upland forest" in the middle tier of the zopotal, in flatland forests, among the tallest trees of the marginal forests, among the second-and third-story trees of the flatland high forests, among the third-story trees of the high forests on well-drained uplands, and in the secondary forests covering abandoned milpas on the Yucatán Peninsula. He calls it a characteristic tree of the limestone area in British Honduras. Steggerda writes the name "yaax nic"; "illlspaugh in the reference cited above records the name "yaxnic", although he erroneously identifies Gaumer 607 as $\mathrm{V}$. pyramidata B. L. Robinson, a more northern kexican species not as yet known from the Yucatan Peninsula. Gentle 1756 was deternined and distributed by Standley as $\mathrm{V}$. kuylenii, but is identical with the two Humel collections. These three sterile collections apparently represent an anomalous British Honduran form of $\mathrm{V}$. gaumeri with very sparse pubescence, or else represent leaves taken from coarse-growing watersprouts. The species has also been confused with and misidentified as $\mathrm{V}$. umbrosa Sw.

Schipp describes the species as a "giant forest tree growing on broken pine ridge, in a poor class of soil composed mainly of quartzite". He states that the tree has a spreading crown and that the hard wood is yellow and fairly tough, or, on another label, white when felled and close-grained. On one label he says "wood soft, never used". Again, he describes it as "a large tree growing in primary forests, in poor soil, magnificent with its bright blue flowers and yellow fruit, occasional". He reports a tree 40 feet tall and 9 inches in diameter; another 40 feet by 10 inches; another 40 feet by 24 inches; and still another 50 feet by 24 inches. Gaumer reports a tree 60 feet tall and 24 inches in trunk diameter.

It has been collected in anthesis from February to September and in fruit in February, May, June, and July. It is said to be a very handsome tree, with masses of light-blue or sky-blue flowers. Standley reports that "the tough wood is used for the construction of carts, boats, and agricultural implements". Gaumer states that "yax" in the common names in this case means 
"blue", as there is no word for blue in the Mayan language ("yax" really means green!), and "nic" means "flower". He states that in March the flowers are so abundant that the tree looks like a mass of brilliant blue; "the wood is very tough and much sought for in the construction of wagons, boats, and in the decortication of the henequen fiber." Bequaert adds that the leaves are used as a horse fodder and that the tree is called "dachnik", meaning "green ear" in Mayan. It is called "flor azul", "fíor azule", or "barrabas" in Honduras, "barbas" or "jocote de mico" in Guatemala, "yaxnic", "yaaxnic", "yaax nic", or "blue flower" in Yucatán, and "blue blossom", "fiddlewood", "matasano", "monkey fiddle", "yashnik", "yash snick", or "yaxmic" in British Honduras. Two other variant spellings are recorded: "locote de mico" and "matasamo".

The type of the species was collected in the vicinity of Izamal, Yucatán, Mexico, in Narch or April, 1895, by George Franklin Gaumer (no. 607), while the type of $\mathrm{V}$. Iongeracemosa was found in sandy gravel at 600 feet altitude at Quirigua, Izabal, Guatemala, on Nay 31, 1919, by Harry Nichols Whitford and L. R. Stadtmiller (no. 74 ), and is deposited in the United States National Herbarium at Washington. The wood specimen no. 3733 in the Yale School of Forestry is from this latter collection and was taken from a tree 60 feet tall, with a trunk diameter of 16 inches. Bartlett says "diam. $6 \mathrm{ft}$." on a label, but it is not clear what he means by this. A photograph of the tree from which Pittier 8599 was collected is in the United States National Herbarium.

The species is said to inhabit woods, pastures, advanced forests, open river-valley forests, upland sapodilla forests, open forests on semi-arid highlands, and primary forests, and also to be found on hillsides, acahual lands, and heavy clay soil over calcareous substrata, as well as in second growth and in ravines of streams in semi-arid uplands. It ascends from 40 to 1665 meters altitude. Matuda says that it occurs "also in Chiapas". Vature leaves can be seen on Lundell 417 and 4933 and on Stevenson 17. Densely long-villous insect-galls, causing abnormal ovaries and fruits, are to be seen on Lundell 417 at Kew, Hummel s.n. at Kew, and Schipp 313 at washington. The sterile Hummel 67 sheets at Kew, obviously from a sucker and probably from the galled tree from which his unnumbered specimens came, have the largest leaflets yet seen for this species and these have the sparsest pubescence beneath. They also have the vein and veinlet reticulation finely prominulent above, while usually it is indiscernible above and obscure beneath. The Haenke 1519 and 1673 and Steyermark 38121 specimens are sterile and of the glabrescent

\section{form.}

V. gaumeri differs from $V$. pyramidata in being a tree with longer petiolules on its leaflets, the petioles and petiolules being usually velvety-pubescent, the lower leaflet-surface paler, and the flowers smaller, with no villous hairs at the base of the anterior lip on the upper surface and a more pubescent and 
more sharply dentate calyx. Cross-sections of the ovary are seen illustrated in Junell, Symb. Bot. Upsal. 4: fig. 142 a \& b (1934).

Record \& Kuylen describe the tree as growing up "to 90 feet in height, with a well-formed bole 30 inches in diameter; bark smooth, thin, whitish; wood yellowish throughout, moderately hard and heavy, medium-textured, finishes smoothly, not utilized" (see Yale School of Forestry nos. 3733 and 3897). Another wood specimen is preserved on the Edwards 593 specimen in the Arnold Arboretum herbarium. For detailed description of the wood anatomy see Record \& Mell, Timbers Trop. Am. 526--527 (1924). Winzerling says it is $1 \mathrm{a}$ well-known tree here and very common. Compared to Nayflower (Flor de lfayo) which has large pink flowers in big bunches or clusters, it has small purple flowers, a single flower resembles that of the Cortez in shape and size, but not in color (Cortez's flower is yellow)."

Citations: NEXICO: Campeche: C. L. Lundell 1327 (A, Ak--13662, $\mathrm{Ca}-486832, \mathrm{Du}-224418, \mathrm{E}-\mathrm{10176 \overline {62 }}, \overline{\mathrm{F}}-\overline{-700449}, \overline{\mathrm{G}}, \mathrm{Mi}, \mathrm{Mi}, \mathrm{Mi}, \mathrm{N}$, $\mathrm{N}, \mathrm{Nt}$ ); Natuda 3905 (F--1026373, Mh). Tabasco: Matuda 3115 (F1028189, Mh, N $), 3231(\mathrm{~F}--1026860, \mathrm{Mh}, \mathrm{N})$. Yucatán: Bequaert 63 (A, F-710790), 98(A, F-710798); G. F. Gaumer $607 \overline{(A--i s o t y p e, ~}$ B--isotype, Bm--isotype, Br--isotype, Ca--4ل46152--isotype, Cp-isotype, E--116182--isotype, Ed--isotype, F--364l0--isotype, F-437585--isotype, G--type, Gg--159706--isotype, I--isotype, K-isotype, Lu--isotype, Mi--isotype, N--isotype, N--photo of type, S--isotype, S--photo of type, Us--isotype, V--isotype, W268732--isotype, X--isotype, Z--photo of type), 24000 (Bm, Cb, $\mathrm{E}-951543, \mathrm{~F}-552002, \mathrm{Gg}-\mathbf{1 6 0 5 8 1}, \mathrm{N}, \mathrm{W}--1268104$ ), s.n. [Izama], 1888] (F--181603, K); Gaumer \& sons 23251 ( Cb, E--804641, F-$446682, \mathrm{G}, \mathrm{N}, \mathrm{Oa}$, Ur, $\overline{\mathrm{W}--342261)}, 23567(\mathrm{Ca}-446068, \mathrm{Cb}, \mathrm{Cp}, \mathrm{E}-$ $953808, \mathrm{~F}-465942, \mathrm{Mi}, \mathrm{N}, \mathrm{W}--1265875$ ), 23568 (A, Bm, Cb, F-465944, Gg--160537, K, N, S, Us, V, W--1265876); Lundell \& Lundell 7321 (Mi, Ni, N); A. C. V. Schott 582 (F--195496, F-二195498); Steere 1558 (E--1087003, $\mathrm{F}=-6 \overline{68} 5 \overline{86, \mathrm{La}}, \mathrm{Me}, \mathrm{Mi}, \mathrm{N})$; Steggerda

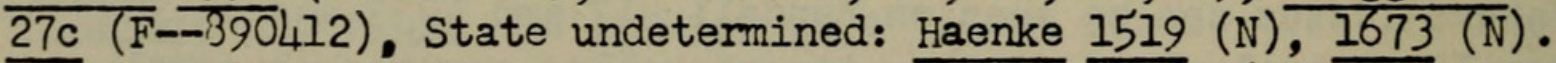

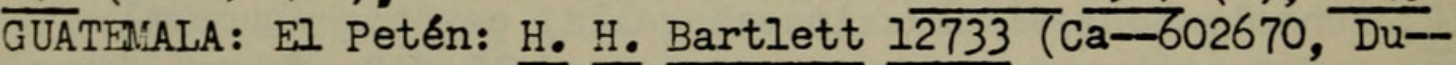
$240843, \mathrm{E}--1091148, \mathrm{~F}=-6 \overline{63988, \mathrm{Gg}-233204}, \mathrm{G}, \mathrm{I}, \mathrm{K}, \mathrm{Mi}, \mathrm{N}, \mathrm{N}, \mathrm{S}$, W--1493232); Egler L.2-233 (Ld); C. L. Lundeli 1509 (Du--248359, $\mathrm{F}-662349, \mathrm{Mi}, \mathrm{N}, \mathrm{W}=-1588985), 2 \overline{662}(\mathrm{E}--1037158, \mathrm{~F}-685316$, We, $\mathrm{Ki}, \mathrm{S}), 279 \mathrm{I}(\mathrm{F}-685315, \mathrm{Gg}-23 \overline{325 \mathrm{I}}, \mathrm{K}, \mathrm{Mi}), 3540$ (Mi, S). Izabal: Pittier 8599 (N, W--1013498); Steyermark 38121 (F1053117); Whitford \& Stadtmiller 74 (G, N--photo, W--42402, W1012333, Y, Z--photo) . BRITISH HONDURAS: H. H. Bartlett 13130 (Au, Ni, N, N, S); M. Chanek 184 (F--706180, Mi, N); Gentle 63 $(\mathrm{F}-696276), 1756(\overline{\mathrm{F}}-790947, \mathrm{Mi}, \mathrm{Mi}), 2528(\mathrm{Dp}-2905 \overline{3, \mathrm{~F}-}$ $344826, \mathrm{Mh}, \mathrm{Mi,N}), \mathrm{s.n} \cdot$ [Lundell 4933] (E-1043749, I, N, N, S); Heyder I (W--1317233, Y); Heyder \& Kinloch xxxv(W--1405635); Hummel $67(K, K)$, s.n. [Botanic station, 1l.3.2l] (K, K, K); Karling 21 (F--599862, W-1406549); C. L. Lundell 417 (B, Ca- 
406352, Du--189924, F--712046, K, N, W--1472682); W. C. Meyer 6I

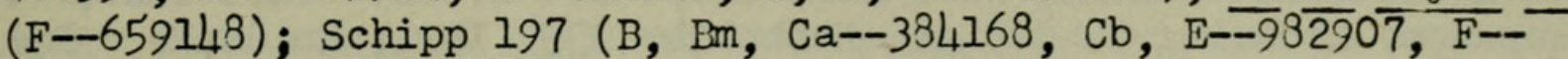
593155, G, J, K, K, אi, N, S, W--1492089), 313 (A, B, Bm, Bm, Ca

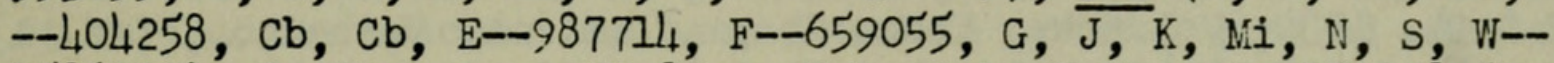
1586293); D. Stevenson 17 [Nus. Yale School Forest. 11997] (F-$572641, Y)$; N. Stevenson s.n. (W--1266026, Y); Winzerling III.3 $(\mathrm{W}-1315701, \overline{\mathrm{Y}})$. HONDURAS : Comayagua: J. B. Edwards 593 (A, B, $\mathrm{Ca}-522764, \mathrm{~F}--638121$, W--1533674), P.141 (A, B, F--662637, W-1588657), P.344 (A, B, Ca--522660, F-662636, W--1588618); Scherzer s.n. (V, V). Copán: Pittier 8470 (G, N, W--1083866). Yoro: Yuncker, Koepper, \& Wagner 8165 (Dp, F--944385, N), 3625 (Dp, F-944381, N).

VITEX GEMINATA H. H. W. Pearson in Thiselt.-Dyer, Fl. Cap. 5: 213--214. 1901.

Iiterature: Pearson in Thiselt.-Dyer, Fl. Cap. 5: 213--214. 1901; Pieper in Engl., Bot. Jahrb. 62, Beibl. 141 ["1/2"] : 56 \& 82. 1923; Moldenke, Known Geogr. Distrib. Verbenac., [ed. 1], 52 \& 103 (1942) and [ed. 2], 122 \& 201. 1949.

Large shrub; branches stout, 6-angled, striate, glabrescent, with a smooth purplish bark; internodes elongate; leaves ternate, 5-foliolate; petioles stout, $2.5--3 \mathrm{~cm}$. long, subterete, ampliate at the base, glabrous except for the puberulent or pubescent base and apex; leaflet-blades coriaceous, oblanceolate, very shortly acuminate, obtuse, entire, somewhat thickened and revolute along the margins, dark-brown and glabrous above in drying, lighter beneath, glabrous except for the puberulent veins, eglandular, the terminal one $6.5-7 \mathrm{~cm}$. long and $2--2.2 \mathrm{~cm}$. wide, the lateral ones smaller; petiolules 2--6 mm. long, grooved, puberulent or glabrous; secondaries 3--12 on each side, spreading, depressed above, prominent beneath; cymes lax, divaricate, a pair in the axil of each leaf, equaling or somewhat exceeding the subtending leaf, bracteate; peduncles angular, $4.5--6.5 \mathrm{~cm}$. long, prominently ribbed, appressed-puberulent; bracts linear-elliptic, 1--1.6 cm. long, acute, attenuate at the base into a stalk about half as long as the blade, puberulent or pubescent; flowers short-pedicellate, ebracteolate, about $1.3 \mathrm{~cm}$. long; calyx campanulate, about $3 \mathrm{~mm}$. long, obscurely nerved, glabrous on the inner surface, finely pubescent outside, its rim unequally and minutely 5-toothed; corolla purplish, its tube slightly curvate, 3--10 mm. long, glabrous below, appressed-pubescent on the outside above, puberulent within above the insertion of the stamens and pubescent in the throat, its limb reflexed, densely pubescent outside, minately so within; stamens inserted below the micidle of the corolla-tube, exserted; filaments ampliate and villous toward the base; ovary subglobose, clabrous, wrinkled; fruit not known.

The type of this species is Gerrard \& $\mathrm{HCKen} 2027$, collected by the Umlatusi River in Zululand.

VITEX GIGANTEA H.B.K., Nov. Gen. \& Sp. Pl. 2: 24,5--246. 1818. 
Literature: H.B.K., Nov. Gen. 2: Sp. Pl. 2: 245--2l,6. 1818; Popenoe, Contrib. U. S. Nat. Herb. 24: 133. 1924; Noldenke, Alph. List Common Names 21. 1939; loldenke, Geogr. Distrib. Avicenn. 22 \& 24. 1939; Noldenke, Known Geogr. Distrib. Verbenac., [ed. 1], 34, 35, \& 103. 1942; Koldenke, Phytologia 2: 119. 1944; Holdricige \& al., Forests West \& Cent. Ecuador 67. 1947; lloldenke, Known Geogr. Listrib. Verbenac., [ed. 2], 70, 74, \& 201. 1949; Acosta Solis, Publ. Dept. Forest. Ecuador 7: 39. 1949.

Tall tree, to $32 \mathrm{~m}$. tall; trunk to $75 \mathrm{~cm}$. in diameter; wood east to cut, strong but somewhat brittle, holds shape and finlshes well, durable; sapwood straw-colored, deepening in color after exposure to air; heartwood light-brown, somewhat lustrous, with no distinctive odor or taste, moderately hard and heavy, with an oven-dry specific gravity of 0.55 , weighing about 34 pounds per cubic foot, with medium texture, the grain variable, from very straight to irregular; branches and branchlets medium-slender, obtusely tetragonal or terete, varying from softly tomentosehirsute to more or less densely puberulent, less so in age, brown; twigs densely short-pubescent with flavescent or fulvous hairs; nodes not annulate, mostly somewhat ampliate; principal internodes $1--5.5 \mathrm{~cm}$. long or more abbreviated; leaf-scars large, corky, prominent; leaves decussate-opposite, usually developed with or after the flowers, 3--5-foliolate; petioles slender, 4.8 $--10 \mathrm{~cm}$. long, densely short-pubescent with flavescent or fulvous hairs, somewhat flattened above, sometimes but usually not canaliculate, not margined nor ampliate at the base; petiolules slender, l--7 mm. long, densely puberulent or short-pubescent like the petioles, canaliculate-margined, the terminal one somewhat longer than the rest; leaflet-blades thin-membranous at time of anthesis, thin-chartaceous when mature, rather uniformly bright- or dark-green on both surfaces or lighter beneath, the immature ones nigrescent in drying, oblong or broadly elliptic, the terminal one $5.7--20 \mathrm{~cm}$. long, $3.1--3.2 \mathrm{~cm}$. wide, acute or acuminate at the apex, entire, acute or acuminate at the base, glabrous or more or less sparsely puberulent above (especially along the midrib and secondaries), rather densely short-pubescent beneath with flavescent or brownish hairs; midrib slender, plane or subimpressed above, rounded-prominent beneath; secondaries slender, 8--15 per side, arcuate-ascending, usually not much arcuate, mostly plane above, prominent beneath, arcuately joined near the margins; vein and veinlet reticulation very fine, abundant, obscure or indiscernible above, prominulent beneath (on mature leaves); inflorescence axillary, cymose, $2--5.5 \mathrm{~cm}$. long, $1.5--4 \mathrm{~cm}$. wide; peduncles about $2.5 \mathrm{~cm}$. long, pubescent; cymes 3--6-flowered; flowers with a slight perfume; calyx campanulate, 5-toothed, the teeth obtusish; corolla lilac or violet, its tube short-cylindric, its limb dilated, bilabiate, the upper lip erect, 2-lobed, the lower lip 3-lobed, spreading, mottled with white toward the pilose base, the central lobe 3 times as long as the lateral ones; filaments pilose at the base; fruit green (in December), the size of an olive, edible.

The type of this rather puzzling species was collected by 
Friedrich lieinrich Alexander vỏn Humboldt and Aimé Jacques Alexandre Bonpland (no. 3853) at Guayaquil, Ecuador, and is deposited in the herbarium of the liuseum National d'Histoire Naturelle at Paris. The species has been found in coastal jungles near sea level, in dense wet or dry tropical forests, and in mountain forests, ascending to 200 meters altitude, blooming in November and fruiting in December. It is called "moconto" and "pechiche". The wood is used for construction, decking for ships and bridges, railway ties, and other purposes where it will be exposed alternately to sun and water. Miss Mexia says of it: "good hard wood, common." Her no. 6177 is in anthesis and is practically leafless. Acosta Solis reports that it is cultivated in the "western region" of Ecuador.

The Mexia 6770 collection is in fruit, with mature pubescent leaves, while the Peruvian specimens are mostly in anthesis with very immature leaves that are very sparsely puberulent above. It is not certain that both populations represent the same species. The plant is obviously very closely related to $\mathrm{V}$. cymosa Bert. and V. flavens H.B.K., with both of which it has been misidentified by herbarium workers. Tessmann 4723 at the Conservatoire et Jardin Botaniques at Geneva is identical with Mexia 6177 in the Britton Herbarium at New York.

Citations: ECUADOR: El Oro: E. L. Little 6634 [Herb. U. S. Dept. Agr. Forest Surv. 95915] (N) . Guayas: Fagerlind \& Wibom 626 (S); Humboldt \& Bonpland 3853 ( $\mathrm{N}-$-photo of type, N--isotype, P-type, P--isotype, P--isotype, Z--photo of type); Nexia 6770 (F--863746, N, N--photo, Qu, S, W--1592023, Z--photo); ville s. n. [Guayaquil, 1926] (F-920240). Los Ríos: Nexia 6679 (N); 15yer \& Little 6504 [Herb. U. S. Dept. Agr. Forest Surv. 95914] (N). Province undetermined: Bonpland s.n. (N, P). PERU: Niexia

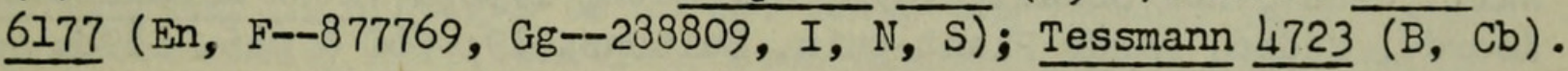

VITEX GIORGII DeWild., Contrib. Etud. Fl. Katanga Suppl. 2: 103104. 1929.

Literature: DeWild., Contrib. Etud. Fl. Katanga Suppl. 2: 103 -104. 1929; Moldenke, Known Geogr. Distrib. Verbenac., [ ed. 1], 49 \& 103. 1942; H. N. \& A. L. Moldenke, Pl. Life 2: 61. 19L8; Noldenke, Known Geogr. Distrib. Verbenac., [ed. 2], 115 \& 201. 1949.

Shrub; branches subtetragonal, short-tomentose and grayyellowish toward the apex, glabrescent below; leaves 5-foliolate, the central leaflet usually larger than the others; petioles not canaliculate above, more or less flattened toward the base, short-tomentose; petiolules 3--1l mm. long; leaflet-blades lanceolate-elliptic, $3--11 \mathrm{~cm}$. long, $1.6--4.8 \mathrm{~cm}$. wide, more or less long-acuminate at the apex, entire, cuneate at the base and narrowed into the petiole, glabrous above, densely tomentose beneath; secondaries about 17 pairs, somewhat prominent beneath; tertiaries subparallel but difficult to discern because of the tomentum; inflorescence axillary, cymose; peduncles $3.5-6 \mathrm{~cm}$. long, short- 
tomentose; cymes loose, many-flowered, more or less dichotomously branched, the branches to $11 \mathrm{~mm}$. long; bractlets shorttomentose, to $17 \mathrm{~mm}$. long, caducous, the lower ones filiformlanceolate, the upper ones filiform; flowers pedicellate, more than 20 per inflorescence; pedicels $1--7 \mathrm{~mm}$. long, velutinous, the longest ones at the center of each dichotomy; calyx campanulate, about $3 \mathrm{~mm}$. long, subbilabiate, velutinous or short-toientose on the outside, glabrous within, the lips obscurely dentate, the teeth rounded and short; corolla short-tubular, the tube 4$5 \mathrm{~mm}$. long, velutinous outside, the limb 5-lobed, the anterior lobe cuneate, about $2.5 \mathrm{~mm}$. Iong and $3 \mathrm{~mm}$. wide, velutinous on the outer surface, glabrous on the inner surface; ovary subglobose-subtruncate, sparsely glandulose, pilose at the apex.

The type of this species was collected by S. de Giorgi (no. 391) -- in whose honor it is named - at Etoile du Congo, Belgian Congo, in January, 1923. The species is said by DeWildeman to be very closely related to $V_{\text {. }}$ bequaerti Dewild. He knew V. giorgii only from a single flowering branch, while V. bequaerti was originally described from material in the fruiting condition. later collections of the latter, however, agree well with the type. V. giorgii has larger leaves, the pubescence on the lower surface of the leaflets is more cottony-villous, and the smaller venation is not clearly visible as it is in V. bequaerti.

VITEX GLABRATA R. Br., Prodr. 512. 1827.

Synonymy: Vitex cunninghami Schau. in A. DC., Prodr. 11: 691. 1847. Vitex cunninghami DC. ex Ettingsh., K. Akad. Wiss. Wien Denkschr. 28: 219 [Fossile Flora Bilin 2: 31]. 1868. Vitex leucoxylon Schau. apud Watt, Dict. Econom. Prod. Ind. $6(4): 247$, in syn. 1893 [not V. leucoxylon L. f., 1781, nor Roxb., 1814, nor Wall., 1847, nor Schau., 1893, nor Roth, 1956]. Vitex minahassae Koord., Meded. Lands Plant-tuin. Buitenz. 19: $560 \& 645.1898$. Vitex helogiton K. Schum. in K. Schum. \& Lauterb., Nachtr. Fl. Deutsch. Sudsee 362. 1905. Vitex pentaphylla Merr., Philipp.

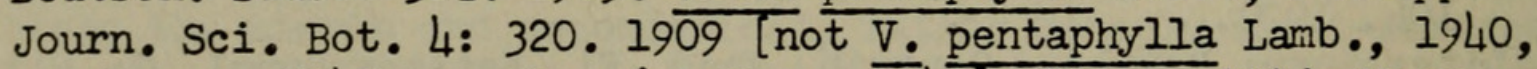
nor Pavon, 1940, nor Sessé \& Moc., 1940]. Vitex nitida Merr., Philipp. Journ. Sci. Bot. 7: 343. 1912. Vitex cunninghamii Schau. apud H. J. Lam, Verbenac. Malay. Arch. 204, in syn. 1919. Vitex glabrata Blume, in herb. Vitex macrocarpa Koord. \& Val., in herb.

Literature: Rheede, Hort. Ind. Malab. 4: 75--76, pl. 36. 1683; R. Br., Prodr. 512. 1827; Schau. in A. DC., Prodr. 11: 691 \& 695 . 1847; W. Elliot, Fl. Andhr. 134. 1859; Dalz. \& Gibs., Bombay Fl. 201. 1861; Benth. \& Muell., Fl. Austral. 5: 31. 1870; Brandis, For. Fl. NW. \& Cent. India 3: 370. 1874; Kurz, For. Fl. Brit. Burma 2: 273. 1877; Ind. Forester 10: 222. 1384; C. B. Clarke in Ilook. f., Fl. Brit. Ind. 4: 588. 1885; J. C. Lisboa, Useful PI. Bombay 108. 1836; K. Schum. \& Hollmung, Fl. Kaiser-Wilhelmsl. 121. 1389; Watt, Dict. Econom. Prod. Ind. 6 (4): 247. 1893; Jacks., Ind. Kew. 2: 1213. 1895; Koord. \& Val., Bijdr. Booms. 7: 208--210. 1900; K. Schum. \& Lauterb., FI. Deutsch. Sudsee 523. 
1900; K. Schum. \& Lauterb., Nachtr. Fl. Deutsch. Sudsee 362. 1905; King \& Gamble, Journ. As. Soc. Beng. 74: 852. 1909; Koord., Exkurs. Fl. Java 3: 137. 1912; Merr., Philipp. Journ. Sci. Bot. 7: 343. 1912; Koord. \& Va?., Atl. Baumart. 2: 6, pl. 299. 1914; Heyne, Nutt. Plant. Nederl. Ind. 4: 113--114. 1917; Basu, Ind. Medic. Pl. 3: 3, pl. 742. 1918; H. Hall., leded. Rijks Herb. Leid. 37: 54. 1918; H. J. Lam, Verbenac. Nalay. Arch. 203--205 \& 369. 1919; H. J. Lam, Bull. Jard. Bot. Buitenz., sér. 3, 5 (2): 175--176. 1922; Bakh. \& Lam, Bull. Jard. Bot. Buitenz., sér. 3, 4 (2): 285. 1922; E. D. Nerr., Enum. Philipp. Flow. Pl. 3: 394 . 1923; Heyne, Nutt. Plant. Nederl Ind. 1316. 1925; H. J. Lam in Engl., Bot. Jahrb. 59: 93. 1925; Stapf, Ind. Lond. 6: 478. 1931; Kanehira, Fl. Micronesia 345. 1933; Crevost \& Pételot, Bull. Econom. Indo-Chine 37: 1294--1295. 1934; Moldenke, Alph. List Common Names 2, 6, 17, 27, 29, \& 30. 1939; Moldenke, Geogr. Distrib. Avicenn. 40. 1939; Noldenke, Suppl. List Common Names 2-4, 8--15, \& 19-22. 1940; Worsdell, Ind. Lond. Suppl . 2: 500. 1941; Kanehira \& Hatusima, Bot. Mag. Tokyo 56: 115. 1942; Moldenke, Known Geogr. Distrib. Verbenac., [ed. 1], 55, 59--61, 63, 64, 66, 70, 75, \& 103. 1942; Moldenke, Alph. List Invalid Names 54. 1942; Moldenke, Phytologia 2: 119. 1944; Bruno \& d'Urso, Giard. Bot. Colon. Semina Anni 1949: 29. 1949; Moldenke, Known Geogr. Distrib. Verbenac., [ed. 2], 125, 128, 129, 137--140, 142, 144, 147--149, 154,165 , \& 201. 1949; H. N. \& A. L. Moldenke, Anal. Inst. Biol. Mexico 20: 15. 1949.

Illustrations: Rheede, Hort. Ind. Nalab. 4: pl. 36. 1683; Koord. \& Val., Atl. Baumart. 2: pl. 299. 1914; Basu, Ind. Medic. P1. 3: pl. 742. 1918; Kanehira, Fl. Kicronesia 345. 1933.

Small to very large stocky or crooked tree, $10-25 \mathrm{~m}$. tall, or a large shrub; trunk $30--125 \mathrm{~cm}$. in diameter, star-shaped at the base, with indications of buttresses $1 \mathrm{~m}$. high, often $20 \mathrm{~cm}$. in diameter at a height of $20 \mathrm{~cm}$. above the ground; bole $15 \mathrm{~m}$.; wood moderately soft, whitish, soon discoloring to dirty-white, odorless, tasteless; bark thick, varying from gray or light-gray to grayish-white, finely checked, rough, peeling off in small nieces; branches numerous above the middle, forming a dense elongated or rounded crown; branchlets obtusely quadrangular, more or less fulvous-pubescent or eventually glabrescent; twigs ascending, greenish-brown, with elongated lighter brown lenticels; leaves deciduous, 3--5-foliolate, glossy-green, on seedlings 1foliolate and serrate; petioles green, ascending, $7--17 \mathrm{~cm}$. long, slender, glabrous or s omewhat pubescent; leaflet-blades varying from membranous to chartaceous or thin-coriaceous, horizontally recurved, strongly conduplicate on the upper sublucid or darker green surface, elliptic or elliptic-oblong, varying to subobovate, sometimes subrotund or lanceolate, brunnescent or subnigrescent in drying, obtusely or acutely acuminate at the apex, varying from broadly cuneate to narrowly long-attenuate at the base, entire (or serrate on seedlings), glabrous except for the midrib and larger venation (when young) above, labrous or very sparsely pubescent beneath and more or less barbellate in the axils, the lowest ones $2.5--10 \mathrm{~cm}$. long and $1--5.5 \mathrm{~cm}$. wide, with $6--8$ 
pairs of secondaries, the lateral ones $14--26 \mathrm{~cm}$. long and 7--11 $\mathrm{cm}$. wide, with $10--12$ pairs of secondaries, and the terminal ones 15--31 cm. long and $3--13.5 \mathrm{~cm}$. wide, with 12--17 pairs of secondaries; midrib minutely pubescent above, glabrous or somewhat pubescent beneath; secondaries slender, 6--17 per side; petiolules $0.2--2 \mathrm{~cm}$. long, variable, those on the terminal leaflets longest and on the lowest leaflets shortest; inflorescence erect, greenish, slightly fragrant; cymes axillary, lax, slender, minutely pubescent, dichotomous, few-flowered, 7--22 cm. long, $7--3 \mathrm{~cm}$. wide; peduncles $2-10 \mathrm{~cm}$. long; bracts small, caducous, about $3 \mathrm{~mm}$. long; pedicels $1--3 \mathrm{~cm}$. long, often bearing 2 minute opposite bracteoles; calyx violet-green, cupuliform, $1.5--4 \mathrm{~mm}$. long, $2.5--3 \mathrm{~mm}$. wide, minutely appressed-pubescent, its rim with 5 small teeth; corolla cream-colored, smudgy-white, or white, varying to yellowish-white, $5--6 \mathrm{~mm}$. long, minutely pubescent throughout on the outside, glabrous below on the inner surface, densely villous in the throat and up to the middle lobe of the lower lip within, the upper lip pink or purplish-streaked, with faintly violet hairs, $5--8 \mathrm{~mm}$. long, $2.5--4 \mathrm{~mm}$. wide, entire, the smaller lobes $2-2.5 \mathrm{~mm}$. long, $1.5--2 \mathrm{~mm}$. wide; stamens exserted, $6--7 \mathrm{~mm}$. long; filaments whitish, villous on the lower half, glandulose on the upper half, stout and ampliate at the base; anthers purplish-brown; style 7--9 mm. long, exserted; stigma shortly bifid; ovary glabrous, minutely villous at the tip; fruit drupaceous, obovoid or bluntly elliptic, $8--20 \mathrm{~mm}$. long, to $10 \mathrm{~mm}$. wide, green or yellow-green when immature, black when ripe, sweet, edible.

Williams reports finding a tree of this species 60 feet tall, with a trunk $14-13$ inches in diameter. It inhabits open grasslands in fertile soil and high rain forests and is common along the edge of evergreen jungles, from altitudes of 5 to 1080 meters, blooming from March to May and July to September, collected in fruit in January, April, and June. It is said to be common in deciduous forests in Thailand.

The type of $\mathrm{V}$. minahassae is Koorders $19553 \mathrm{~b}$ from near Kajoewatoe, commonly called "saoe-sela" or "saoe sĕla" there. The actual type is sheet no, 24132 in the Buitenzorg herbarium, and contains neither flowers nor fruit, its leaves are glabrous beneath and scarcely glandulose. Koorders says that the name "kajoe-gopasa" given on page 560 of his work is an error, as this name applies to $\mathrm{V}$. celebica Koord. $[=\mathrm{V}$. quinata (Lour.) F. N. Will.]

Heyne says of this species "aan de zuidkust met zuilvormigen stam en hoog aangezette kroon, op het Wilisgebergte daarentegen met korten, laag vertakten stam. $H i j$ is verbreid over den geheelen Maleischen Archipel en groeit op Java verstrooid beneden $900 \mathrm{M}$. zeehoogte, doch is op sommige plaatsen nied zeldzaam. Het hout wordt soms voor huisbouw gebruikt: oude boomen zouden bij Tjilatjap zeer vaak hol zijn." He also says "Boom van NoordCelebes, door Koorders alleen gevonden bij Kajawatoe en daar steriel ingezameld; volgens hem (Ninahassa, bl. 560) wordt het hout voor huisbouw zeer hoog geschat. Op bi. 170 heet het goed 
tegen weer en wind bestand en geschkikt voor planken en balken." iVatt says it is "common from South Assam and Cachar to Valacca. Considerable confusion exists in Indian literature between this species and V. leucoxylon, Linn. f., a native of South India and Ceylon, which Kurz, and following him, Gamble, appear to have united. It is probable, however, that most of the information here given refers to $\mathrm{V}$. Elabrata.....The bark and root are used as astringents in the Andaman Islands....The tree flowers in April, and produces a small black fruit containing very soft pulp, which is eaten by the Burmese in the Andaman Islands...... [The wood is] grey with a satiny lustre, hard, close-grained, durable; weight about 42 lbs. per cubic foot. It is used for cart-wheels, and deserves attention for furniture and other purposes." The label on Native collector 343 indicates that the wood is used for fuel supply in Siam. Vidal says it has medicinal uses in Laos.

Material of this species has been found in herbaria misidentified as V. celebica Koord., V. cofassus Reinw., V. cuneata schum. \& Thonn., V. heptaphylla A. L. Juss., V. heterophylla Roxb., V. littoralis Decne., V. loureiri Hook, \& Arn., V. parviflora A. L. Juss., V. pentaphylia Merr., and V. quinata (Lour.) F. N. Will. The Boschproefst. Kiempl. 2065 cited below is said to be the source of Noltee 4060 , while no. 2028 is said to be from the same seed stock as 2065. It consists of small seedlings with l-foliolate serrate leaves.

Watt cites, in addition, V. bombacifolia Wall. and $\mathrm{V}$. pallida Wall. as synonyms, and Lam follows him in this disposition, but I place these two binomials in the synonymy of var. bombacifolia (Wall.) Moldenke.

Common names for the species include "ampapalút", "amulkon", "ashwal", "banga koeba", "bhodiya", "bigboel", "bihbul", "boeboeloe", "boetboet", "bokg6g", "borgúg", "bonkolion", "gŏntileng", "gěntilěng", "gěntileng ketileng ", "goda", "gofasa batoe", "horina", "htoukshar", "kalipápa-aso", "kamoláuan", "karil", "karril", "katendeng tandro", "kelilě̀ng", "ketilèng", "kĕtilëng", "khi hen", "khi-hen", "khi nok", "ki bigchbul", "ki katjapi", "ki now", "laban kětilęng", "laban kětilěng hleng", "longarbi thiras", "longarbis thiras", "luki", "neva-lédi", "popoul ach sat", "popoul tuk", "saoe-sela", "sasalit", "sengeni", "senkane", "sheras", "sherasa", "songarbi", "tálang-puso", "tilěng", "tin nôk", "tokra", and "topas".

Koorders $19547 \mathrm{~b}$ was determined as V. minahassae by Koorders and Valeton in January, 1898, as V. celebica by Koorders in May, 1898 , and as V. quinata by Bakhuizen van den Brink in 1934! Kanehira \& Hatusima, in the reference cited above, cite their no. 14138 from Momi, collected on April 10, 1940, in high rain f'orests at 100 meters altitude. They give as the distribution of the species "India, Malaya, Philippines, Micronesia, and northern Australia". Lam cites, in addition to material cited below, Ledermann 10474 from Northeastern New Guinea, Forbes 3784 from 
Timor, and Junghuhn s.n. [Herb. Lugd.-Bat. 908267-1210 \& 1220], Korthals s.n. [Herb. Lugd.-Bat. 908272-136], and Kuhl \& Van Hasselt s.n. [Herb. Iugd.-Bat. 909107] from Java. He gives as this species' distribution: "Britisch Indien, Siam, Burma, Cochinchina, Malayische Halbinsel, Java, Timor, Neu Guinea, Palawan, Mindanao, Nord-Australien, Queensland". Merrill, in his Enumeration of Philippine Flowering Plants, states that it is found also on the islands of Balabac and Negros, and cites, in addition, lerrill 2162, Klamme s.n. [Herb. Philipp. Forest. Bur. 19546], Miranda s.n. [" Herb. Philipp. Forest. Bur. 20633 \& 20771], Razon s.n. [Herb. Philipp. Forest. Bur. 23671], Somonte s.n. [Herb. Philipp. Forest. Bur. 24317], and Thitford \& Hutchinson s.n. [Herb. Philipp. Forest. Bur. 9490].

Citations: INDIA: West Bengal: Helfer 17 (Bz-24143, N, S); King's Collector 407 (Na--16232). BURNA: Upper Burma: Kurz 2382 (Bz-23809). INDOCHINA : Laos: Vidal $360(\mathrm{Z})$, 1843 (Z). State un-

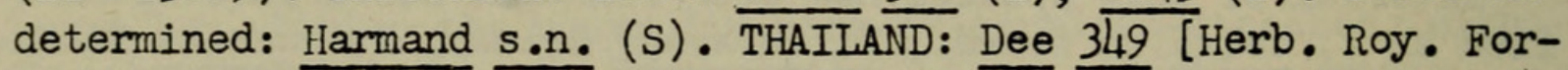
est Dept. 76 $\overline{38](\mathrm{Z})}$; Kostermans 99 (Bz- 73300), 705 (Bz--73303); Native Collector $343 \overline{(S) \text {; Pierre } 110}$ (S); Smitinand 1415 [Herb. Roy. Forest Dept. 7797] (2) . PHILIPPINE ISLANDS: Culion: Ponce s.n. [Herb. Philipp. Forest. Bur. 23904] (Bz-24l17). Luzon: Ahern $110(B z--24564), 1104$ (Bz--24118); Sulit s.n. [Philipp. Nat. Herb. 2646] (Bz--7 $\overline{2681}$ ). Mindanao: W. I. Hutchinson s.n. [Herb. Philipp. Forest. Bur. 11245] (N); Ramos \& Pascasio s.n. [Herb. Philipp. Bur. Sci. 34472] (N); R. S. Williams 2949 (Ms, $\mathrm{N}, \mathrm{N}, \mathrm{N}$ ), s.n. [June 16, 1905] (Ms). Mindoro: M. Ramos s.n. [Herb. Philipp. Bur. Sci. 39371] (Bz--24563). Palawan: Cenabre s.n. [Herb. Philipp. Forest. Bur. 29988] (N); E. D. Merrill 9330 (Bz-2L119, N). JAVA: Berger I [Boschbouwproefst. Ja.125] (Bz$24046)$; Boer 4060a (Bz--24048, Bz--24049, Bz--24050); Boschwezen 103 [Herb. Bot. Var. 453] (Bz-24047); Koorders 9738b (Bz-24072), $9739 \mathrm{~b}(\mathrm{Bz}--214069, \mathrm{Bz}-24070), 9740 \mathrm{~b}(\mathrm{Bz}--24071), 9743 \mathrm{~b}$

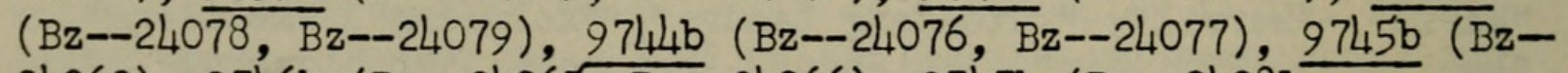
24063), 9746b (Bz--24065, Bz--24066), $9747 \mathrm{~b}(\mathrm{Bz}-24081, \mathrm{Bz}-$ 24032), 9748b $(\mathrm{Bz}-24064)$, 9749b $(\mathrm{Bz}--24080)$, 9793b, in part $(\mathrm{Bz}-24059, \mathrm{Bz}--24060), 9825 \mathrm{~b}(\mathrm{Bz}-24039), 984 \overline{3 b}(\mathrm{Bz}--24033)$, $10129(\mathrm{Bz}-24068), 11058 \mathrm{~b}(\mathrm{Bz}-24083, \mathrm{Ut}--5 \overline{3724)}, 12467 \mathrm{~b}(\mathrm{Bz}-$ $24036, \mathrm{Bz}-24087), \overline{12912 \mathrm{~b}}(\mathrm{Bz}-24090), 2007.5 \mathrm{~b}$ [1008c] (Bz--24061, $\mathrm{Bz}-24062), 27046 \mathrm{~b}$ [691*] (Bz--24084, Bz-25657), 28170b [96d]

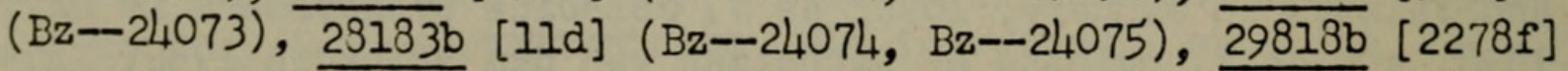
(Bz--24093, Bz--24094, Ut--58725, Ut--58726), 36092b (Bz--24091, Bz-24092); Nartono 15 [Boschbouwproefst. Ja.2815] (Bz--24054); Noltée 4060 (Bz--24057); Van Steenis 3247 (Bz--24053); Veer 53 [Boschbouwproefst. Ja.3305] (Bz-24145). BORNEO: Zwaan 824 [Boschbouwproefst. BB.18819] (Bz--25444). CELEBES: G. R. Bish 4 [Boschbouwproefst. BB.5570] (Bz-24123); Boschbouwproefst. $\overrightarrow{\mathrm{BB}}$. 
$5570(\mathrm{Bz}-24124), 6038(\mathrm{Bz}--24138, \mathrm{Bz}--24139, \mathrm{Bz}-24140, \mathrm{Bz}-$ 2414I, N), Cel./I. 85 (Bz--24123, Bz--24129); Herb. Bogoriense 23340 (Bz); Glam 4 (Bz--24137), 24 (Bz--24136); Koorders 19547b [980] (Bz--25108), $19553 \mathrm{~b}$ (Bz--24132, Bz--24133, N--photo, Zphoto); Laleno 26 [Boschbourproefst. BB.18025] (Bz--24126); Reppie 342 [Boschbouwproefst. BB.24999] (Bz--2L121); Teijsmann 12479 (Bz--2384I); A. Uno 21 [Boschbouwproefst. BB.15374] (Bz24122); Verhoef 105 [Boschbouwproefst. BB.19590] (Bz--2L126); Nalangitang 6 [Boschbouwproefst. BB.3027] (Bz--23864, Ut--80726), 85.0.1 [Boschbouwproefst. Cal./I.85] (Bz-24127); Waturandang 35 [Boschbouwproefst. BB.21108] (Bz-24135), 45 [Boschbouwproefst. BB.21118] (Bz-24134). KANGEAN ARCHIPELAGO: Eteng: Backer 27467 $(\mathrm{Bz}-2 \mathrm{~L}, 099), 27850(\mathrm{Bz}-24100, \mathrm{Bz}-24101)$. Kangean: Backer 27012 (Bz--24.095, Bz--24096, Bz--24097, Bz-24098, Bz--25656) . LESSER SUNDA ISLANDS: Bali: Voogd 1695 (Bz--2L,102). Timor: Damanae 6 [Boschbouwproefst. BB.9712] (Bz-25436, Bz-25437); Nas Nasiran 3 [Boschbourproefst. BB.23954] (Bz-24103); Sastrodihardjo s.n. [Boschbouwproefst. BB.6876] (Bz--24106); Talakua 8 [Boschbouwprofst. BB.9809] (Bz--25434, Bz-25435); Walsh-HeId 214 (Bz-$24104, \mathrm{Bz}-24105, \mathrm{Bz}-25655)$. MOLUCCA ISLANDS: Mangole: Asda \& Anta 26 [Boschbouwproefst. BB.29773] (Bz-25088). Tanimbar Is= lands: Buwalda 44 [Boschbouwproefst. BB.24263] (Bz--24107). NEW GUINEA: Dutch New Guinea: Anang 8 [Boschbouwproefst. BB.28910]

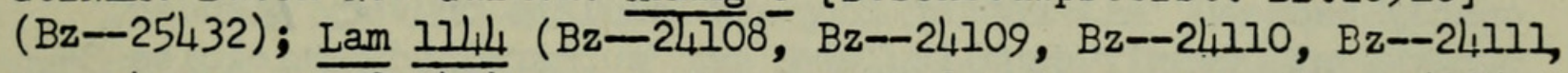
$\mathrm{Bz}-24112$, Ut--80740); Meyer Drees 273 [Boschbouwproefst. 25665] $(\mathrm{Bz}--24114$ ), 583 [Boschbouwproefst. BB.25755] (Bz--24113). Northeastern New Guinea: Hollmung 672 (Bz--24115), 708 (Bz-2L116, Mb). AUSTRALIA: Northern Territory: . Holtze s.n. [Pt. Darwin; Herb. Prager 18673] (Cm, Gg-31482). CULTIVATED: Java: Boschproefst. Kiemplanten 2065 [mother plant 65] (Bz--24056); Burger s.n. [Boschproefst. 2028] (Bz-24055); Herb. Hort. Bot. Bogor. XI.I. 15 $(\mathrm{Bz}-25316, \mathrm{~N}), \mathrm{XI} . \mathrm{I} .36(\mathrm{Bz}-25840, \mathrm{~N}), \mathrm{XI} . \mathrm{I} .36 \mathrm{a}(\mathrm{Bz}-2584 \mathrm{I}, \mathrm{Bz}$, N), XI.J.I (Bz--24130, Bz-24131), XI.J.28 (Bz--25829, Bz-26587, $\mathrm{Bz}$, N), XI .K.2L (Bz--25870), s.n. (Bz-24484, Bz--2LL85). Madagascar: Collector undesignated 299 (Le--29936, N--photo, Zphoto). Mauritius: Herb. lauritius Forestry Dept. s.n. [18.1.36] $(K, K)$; Herb. lus. Paris. s.n. (P).

VITEX GLABRATA var. BOMBACIFOLTA (Wall.) loldenke, Revist. Sudam. Bot. 5: 2. 1937.

Synonymy: Vitex leucoxylon Roxb., Hort. Beng. 46, hyponym. 1314 [not V. leucoxylon L. f., 1781, nor Wall., 1347, nor Schau., 1893]. Vitex bombacifolia Wall., Iumer. List [48], no. 1749, hyponym (1829); C. B. Clarke in Hook. f., Fl. Brit. Ind. 4: 583, in obs. 1385. Vitex pallida Wall., Numer. List [48], no. 1751, hyponym. 1829. Vitex elegans Griff., Notul. 4: 740. 1854. Vitex leucophaea Nall. ex koldenke, Prelim. Alph. List Invalid Names 
51, in syn. 1940. Vitex bombacifolium Wall., in herb. Vitex leucophoea Wall., in herb. Vitex leucoxylon Roth, in herb. [not V. leucoxylon L. f., 1781, nor Wall, 1847, nor Schau., 1893]. Literature: Roxb., Hort. Beng. 46. 1814; Wall., Numer. List [48], nos. 1749 \& 175́1. 1829; Griff., Notul. 4: 740. 1854; C. B. Clarke in Hook. f., Fl. Brit. Ind. 4: 588. 1885; Watt, Dict. Econom. Prod. India 6 (4): 247. 1893; H. J. Lam, Verbenac. Malay. Arch. 204 \& 369-370. 1919; Moldenke, Revist. Sudam. Bot. 5: 2 . 1937; Koldenke, Geogr. Distrib. Avicenn. 40. 1939; Noldenke, Prelim. List Invalid Names 50 \& 51 . 1940; Noldenke, Alph. $L_{i}$ st Invalid Names 52-54. 1942; Moldenke, Known Geogr. Distrib. Verkenac., [ed. 1], 55, 75, \& 103 (1942) and [ed. 2], 128, 129, 165, \& 201. 1949.

Shrub or tree; branchlets stout, obtusely or subacutely tetrafonal, medullose, flattened and ampliate at the nodes, gray or almost white, minutely puberulent, becoming glabrate in age; twigs slender or stoutish, rather short, brown, minutely puberulent, becoming less so or even glabrescent in age; nodes annulate; principal internodes $1--5 \mathrm{~cm}$. long; leaf-scars large, very corky and elevated on branchlets; buds densely pubescent; leaves decussate-opposite, 3-5-foliolate, usually fully expanced during anthesis; petioles slender, $8.5-11 \mathrm{~cm}$. long, minutely puberulent throughout, not at all or but very slightly ampliate at the base, slightly disciform at the apex, convex beneath, flattened and canaliculate above; leaflets subequal or the 2 lowermost considerably reduced, all rather long-petiolulate on very slender, puberulent, deeply canaliculate, and submargined petiolules 3$35 \mathrm{~mm}$. long; leaflet-blades submembranous or thin-chartaceous, rather uniformly dark-green on both surfaces or slightly lighter beneath, mostly brunnescent in drying, the central one broadly elliptic or ovate when mature, $7--18 \mathrm{~cm}$. long, $2.5-8.3 \mathrm{~cm}$. wide, rather long-acuminate or subcaudate at the apex, entire, rather abruptly short-acuminate at the base, sparsely strigillose-puberulent on both surfaces or glabrescent on the lamina in age, quite canescent along the midrib and secondaries on both surfaces when immature, the lateral ones similar in all respects only smaller and usually shorter-stipitate; midrib slender, flat or subimpressed above, prominent beneath; secondaries slender, 817 per side, arcuate-ascending, f'lat or subprominulent above, prominulent beneath, obscurely joined at the margins beneath; vein and veinlet reticulation rather sparse or fine and abundant, usually subprominulent above, obscure or the larger portions subprominulent beneath; inflorescence axillary, cymose, large and abundant, $3--25 \mathrm{~cm}$. long, $3--14 \mathrm{~cm}$. wide, very divaricate, very loosely and laxly many-flowered, long-pedunculate, 4--7 times dichotomous, the branches long and sl ander and widespreading; peduncles very slender, flattened, $4.5--11 \mathrm{~cm}$. long, minutely puberulent or subglabrate in age, more or less annulate at the apex with a band of denser pubescence; inflorescencebranches slender, elongate, flattened, puberulent, and annulate like the peduncles; pedicels obsolete or very slender, puberulent, and to $1 \mathrm{~mm}$. long; bractlets and prophylla linear, $1--3 \mathrm{~mm}$. 
long, sessile, puberulent.

The variety is based on wilich 1749-1 (also referred to as "1749a") and 1749-2, the former collected from a cultivated tree in the Calcutta Botanic Garden, and the latter collected at Tagtomen on the Irawaddi in 1326. The type of $\mathrm{V}$. eleaans is Griffith s.n., collected from a tree cultivated in his own garden at Fergui in Tenasserim, Burma. The type of $\mathrm{V}$. pallida is Wallich 1751 from liarteban in Tenasserim, Burma, although the original publication says "lalabarica" in error.

The variety has been collected in flower in liay. Specimens have often been distributed as typical $\mathrm{V}$. Elabrata. The only common name recorded for it is "popoul ach sat", used in Cambodia.

Citations: INDIA: Assam: Chatterjee s.n. [Shokuti, lay 1902] (Po--63440). State undetermined: Helfer s.n. [India or.] (V, V); Roxburgh $2512(\mathrm{Br})$; Wallich s.n. (Cp, Cp, N-photo, T, Z--photo). BURMA : Tenasserim: H. Falconer 509 (Le); W. Griffith 6062 (Er, Ut--9420La); Wallich 1751 (Cb, E--photo, $\bar{N}, \overline{N--p h o t o, ~ Z--p h o t o) . ~}$ INDOCHINA: Cambodia: Bejaud 519 (N). CULTIVATED: Burma: W. Griffith s.n. [Mergui] (K). India: Herb. Hort. Bot. Calcutt. s.n. $\overline{(\mathrm{Cm}}, \mathrm{K}, \mathrm{Le}, \mathrm{Nu}-650, \mathrm{Nu}--1136, \mathrm{~N})$; Wallich $929 \overline{\mathrm{Cp}), 174, \overline{9}}$ [1749a] (Cb--cotype, Cb--cotype, Cb--cotype, Cb--cotype, K-cotype, N--photo of cotype, Z--photo of cotype).

VITEX GLABRATA var. POILANEI Moldenke, Phytologia 4: 61. 1952.

This variety differs from the typical form of the species in having the lower surface of the leaflet-blades decidedly strigillose even when mature.

The type of the variety was collected by Eugène Poilane (no. 40849, not "40829" as stated in my original publication) near Bien Loa, Cochinchina, Indochina, on ray 25, 1919, and is deposited in the Herbarium Bogoriense at Buitenzorg. The variety has hithert been confused with the typical form of the species.

Citations: INDOCHINA: Cambodia: Pierre 1213 (iv). Cochinchina: poilane 40349 (Bz--72931--type, N--photo of type, Z--photo of type).

VITEX GOLUNGENSIS J. G. Baker in Thiselt.-Dyer, Fl. Trop. Afr. 5: 330. 1900.

Synonymy: Vitex doniana Hiern apud Pieper in Engl., Bot.

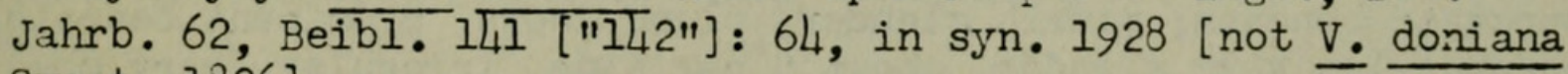
Sweet, 1326].

Literature: Hiern, Cat. Afr. Pl. Welw. 4: 336--337. 1900; J. C. Baker in Thiselt.-Dyer, Fl. Trop. Afr. 5: 330. 1900; Pieper in Engl., Bot. Jahrb. 62, Beikl. 141 ["142"]: 48, 64, \& 82. 1923; Noldenke, Known Geogr. Distrib. Verbenac., [ed. 2], 119 \& 201. 1949.

Shrub, 2.5-- $4 \mathrm{~m}$. tall; branchlets short-pubescent; leaves 5foliolate; petiole $12.5--15 \mathrm{~cm}$. long; leaflet-blades moderately firm, green on both surfaces when mature, obovate-cuneate, the central one $12.5--15 \mathrm{~cm}$. long and $6.25--7.5 \mathrm{~cm}$. wide, entire, 
obtuse or cuspidate at the apex, obscurely pubescent on both surfaces when mature, all the leaflets distinctly petiolulate; cymes dense, axillary, long-pedunculate, the branches appressedpubescent; calyx campanulate, about $2 \mathrm{~mm}$. long, pubescent, its rim dentate with distinct deltoid teeth; corolla small; fruit not known.

The species is based on Welwitsch 5635 from the province of Golungo Alto, Angola. Pieper, in the reference cited above, quotes this as "5636" in error and states that it was available to him for examination. Of the other two numbers cited by Baker he says that he has seen no. 5696 and that it appears to be $\mathrm{V}$. madiensis var. milanjiensis (Britten) Pieper, from which, along with V. holocalyx J. G. Baker and V. doniana Sweet, he appears unable to separate it in his key. This number, however, is actually the type collection of $\mathrm{V}$. madiensis var. parvifolia Hiern, which, in turn, is a synonym of $\mathrm{V}$. holocalyx.

VITEX GRANDIDIANA Pieper in Engl., Bot. Jahrb. 62, Beibl. 141 ["142"]: 78, hyponym. 1928; Fedde, Repert. 26: 165. 1929. Synonymy: Vitex grandidiana Scott-Elliot ex Noldenke, Known Geogr. Distrib. Verbenac., [ed 1], 53 \& 103, sphalm. 1942.

Literature: Pieper in Engl., Bot. Jahrb. 62, Beibl. 141 ["142"] : 73 \& 82. 1928; Pieper in Fedde, Repert. 26: 165. 1929; Moldenke, Known Geogr. Distrib. Verbenac., [ed. 1], 53 \& 103. 1942 ; H. N. \& A. L. Moldenke, P1. Life 2: 62. 1948; Moldenke, Known Geogr. Distrib. Verbenac., [ed. 2], 123 \& 201.1949.

Large shrub or small tree; branchlets slender, gray, obtusely tetragonal, densely short-pubescent with appressed, antrorse, brown hairs on the youngest parts, glabrescent in age; nodes not annulate; principal internodes $0.7--5 \mathrm{~cm}$. long; leaves decussateopposite, l-foliolate; petioles rather stoutish, 5--14 mm. long, flattened and canaliculate above, densely short-pubescent with brown, appressed, antrorse hairs or merely puberulent in age; blades rather firmly chartaceous or coriaceous, uniformly grayish-green on both surfaces, dull, elliptic or oblong-elliptic, $2.5--9 \mathrm{~cm}$. long, $1.6--5.3 \mathrm{~cm}$. wide, varying from rounded or obtuse (on smaller leaves) to short-acuminate at the apex, entire or often irregularly dentate, often somewhat revolute along the margins, truncate or rounded at the base, glabrous on both surfaces or obscurely pilosulous along the midrib above, impressedpunctate beneath; midrib slender, plane above, prominent beneath; secondaries very slender, about 6 per side, irregular, very obscure or indiscernible above, prominulous beneath, arcuately joined in many loops near the margins beneath; veinlet reticulation indiscernible above, subprominulous beneath; inflorescence axillary, few-flowered, much shorter than the subtending leaves, the cymes subsessile, 3--5-flowered; pedicels very slender, very densely villous with fulvous divergent hairs; bractlets broad, ovate, about twice as long as wide, membranous, ligntly pubescent, with plainly visible venation; calyx campanulate, herbaceous, deeply lobed to below the middle, its tube $5--6 \mathrm{~mm}$. long and $6 \mathrm{~mm}$. wide at the apex, densely fulvous-villous, the 5 lobes 
ovate, 6--7 mm. long, attenuate-acute at the apex, more sparsely villous-pubescent, long-ciliate on the margins, the hairs fulvous; corolla infundibular or hypocrateriform, with normal development, varying from rose to red-orange or red, tinged winecolor in age, the tube about $15 \mathrm{~mm}$. long, very densely villous with fulvous divergent hairs, the lobes $4--5 \mathrm{~mm}$. long, villous on the back; stamens exserted about $5 \mathrm{~mm}$. from the corolla-tube; ovary merely glandular.

The type of this endemic Madagascar species was collected by George Francis Scott Elliot (no. 2517) at Fort Dauphin. The species grows among rocks of laterite and granite, at altitudes of 20 to 1000 meters, and has been collected in anthesis from $:$ arch to lin and in July.

Citations: MADAGASCAR: Decary 10010 (P), 10040 (N, P); Humbert 20616 (N, P); Scott Elliot 2517 (K--isotype, $\mathrm{N}$--photo of isotype, Z--photo of isotype), 3007 (K).

VITEX GRANDIDIANA var. ANGUSTIFOLIA Noldenke, Phytologia 3: 436. 1951.

This variety differs from the typical form of the species in having its leaves narrowly oblong-elliptic or oblanceolate, attenuate-acute or cuneate at the base, often more or less dentate toward the apex, and only $1--2.3 \mathrm{~cm}$. wide.

The type of the variety was collected by Martin François Geay (no. 6702) between Fort Dauphin and Santa Luce, in the province of Fort Dauphin, Madagascar, in 1909 or before, and is deposited in the hervarium of the Muséum National d'Histoire Naturelle at Paris.

Citations: MADAGASCAR: Geay 6702 (N--photo of type, P--type, Z--photo of type), $6703(\mathrm{~N}, \mathrm{P})$.

VITEX GRANDIFOLIA Gurke in Engl., Bot. Jahrb. 18: 169. 1394.

Synonymy: Vitex bipindensis Gurke in Engl., Bot. Jahrb. 33: 295. 1904. Vitex Iutea A. Chev., Expl. Bot. Afr. Occid. Franç. 1: 506--507, hyponym. 1920. Vitex babongensis Engl., Pflanzenw. Afr. 5 (1): 192, nom. nud. 1925. Vitex grandifolia var. bipindensis (Gurke) Pieper in Engl., Bot. Jahrb. 62, Beibl. $1_{41}$ ["142"]: 73 \& 81. 1928.

Literature: Gurke in Engl., Bot. Jahrb. 18: 169. 1894; J. G. Baker in Thiselt.-Dyer, Fl. Trop. Afr. 5: 324. 1900; Gurke in Engl., Bot. Jahrb. 33: 295. 1904; A. Shev., Veg Util. Afr. Trop. Franç. 280. 1917; A. Chev., Expl. Bot. Afr. Occid. Franç. 1: 506--507. 1920; Mildbr., Ergebn. Zent.-1fr.-Exped. 1.910/11, 2: 90. 1922; Engl., Pflanzenw. Afr. 5 (1): 192. 1925; Hill, Ind. Kew. Suppl. 6: 219. 1926; Pieper in Engl., Bot. Jahrb. 62, Beibl. 141 ["142"]: 52, 73, \& 30--32, pl. 10. 1923; Pellegrin, Bull. Soc. Bot. France 84: 644. 1937; loldenke, Prelim. Alph. List Invalid Names 50. 1940; Worsdell, Ind. Lond. Suppl. 2: 500. 194l; Noldenke, Alph. List Invalid Names 52 \& 54. 1942; Noldenke, Known Geogr. Distrib. Verbenac., [ed. 1], 46--48, 53, 75, \& 103. 1942; Moldenke, Phytologia 2: 119--120. 1944; Moldenke, Knom 
Geogr. Distrib. Verbenac., [ed. 2], 111--1]4, 124, 165, \& 201. 1949.

Illustrations: Pieper in Engl., Bot. Jahrb. 62, Beibl. 141 ["142"] : pl. 10. 1928.

Semi-herbaceous shrub or small tree, to $4 \mathrm{~m}$. tall; branches and branchlets very stout, obtusely tetragonal, gray, obscurely pulverulent or glabrous, often hollow; twigs stout, very darkbrown in drying, plainly 4- or 8-angled, pulverulent-puberulent or glabrous, mostly hollow; nodes distinctly annulate, sonewhat flattened and ampliate; principal internodes $1--10 \mathrm{~cm}$. long; leaves decussate-opposite, 5-foliolate; petioles stout, $9--15 \mathrm{~cm}$. long, dark-brown in drying, flattened or shallowly and widely canaliculate above, convex beneath, somewhat ampliate at the base, densely but obscurely puberulent throughout with extremely short brownish hairs, somewhat flabelliform at the apex; petiolules $1--5 \mathrm{~mm}$. long, deeply canaliculate-margined and minutely puberulent like the petioles or mostly subobsolete; leafletblades chartaceous, often rather thick and moderately firm, green or dark-green above, lighter green beneath, unequal in size, the central one elliptic or obovate, varying to obovate-cuneate, 16-$30 \mathrm{~cm}$. long, $6-8--15 \mathrm{~cm}$. wide, varying from obtuse to abruptly short-acuminate or cuspidate at the apex, acuminate or cuneate at the apex, acuminate or cuneate at the base, usually prolonged into the petiolules, entire, glabrous on both surfaces or very obscurely and minutely pulverulont above, often somewhat nitid beneath, the lateral ones similar but smaller; midrib flat or subimpressed above, often more or less undate in drying, very stout and rounded-prominent beneath; secondaries very slender, 10--15 per side, ascending, rather uniformly straight and parailel almost to the margins and there arcuate-joined, mostly flat and often undate above, prominulent beneath; vein and veinlet reticulation sparse, obscure or indiscernible above, the larger portions subprominulent beneath; inflorescence axillary or supra-axillary, abundant, shorter than the petioles; cymes $5--7 \mathrm{~cm}$. Iong and wide, dense, many-flowered, dichotomously branched with widely divergent branches; peduncles flat and ampliate, brown, 2--2.5 $\mathrm{cm}$. long (or to $5.5 \mathrm{~cm}$. long at time of fruiting), many-striate, appressed-puberulent; inflorescence-branches rather uniformly 5-$10 \mathrm{~mm}$. long, flattened, brown, many-striate, annulate at both ends, and puberulent or finely pubescent like the peduncles; pedicels none; calyx campanulate, 3-6 mm. long, its rim obscurely toothed; corolla yellow or yellowish, $15--20 \mathrm{~mm}$. long, silky on the outer surface; fruiting-calyx patelliform, incrassate, about $12 \mathrm{~mm}$. wide, irregularly 5-lobed, scarious-margined, glabrate; fruit drupaceous, subglobose, about $1.5 \mathrm{~cm}$. long and wide, hard, slightly 4-lobed and -sulcate, glabrous, nitid, black when dry, yellow, yellow-orange, or yellowish when fresh, 4-seeded, about the size of a small plum or large cherry, edible.

The species has been found both in dry places and in marshes at sea-level, flowering in February and fruiting in July and November. Common names recorded for it are "abisoa", "ada", "adaga", "adefia", "afetewa", "aranga", "bofuluk", "ěbisaa", "fŏ" 
"fó-ti", "fŏ yi", "fŏ yi-ti", "fŏyi-tsho", "God's coconut", "ingari", "ink tree", "kukpweli", "kukui", "lubei", "lugbei", "lugnei", "luwu-wului", "narenga", "nya", "nyamēle-kukwe", "nyarina", "ogikhimi", "okurutu", "orabia", "ore", "రri", "oriri", "ovuruburu", "ǒwenkundigbon", "punyo-tsho", "samanibir", "songsho", "sס̃-tsho", and "uruahu". "Lugbei" is the name for the plant in the Mende tongue in Sierra Leone. Nillen states that a mum, said to be intoxicating, is made from its plum-like fruits, while Deighton reports that "The leaves are dried over a fire and a decoction of them is used as a black ink by the Nohammedans" in the same country.

Chevalier records this plant, misidentified as V. cuneata Schum. \& Thonn., from Senegal, French Guinea, and French Soudan. He cites his nos. 15470, 16508, 17107, 17275, 19091, 19790, and 19819 from Ivory coast. These collections are all cotypes of his V. lutea. Seed of Baldwin 6301 is being grown in cultivation at Williamsburg, Vir

Baker cites in addition Rumsey 14, Barter 20180, Nillen 32 and 64, and Rowland s.n. from Gold Coast, $\overline{\text { Barter }} \overline{2098}$ from Nigeria, Zenker $8 \overline{39}$ and 1006 from Cameroons, and Soyaux 215 and Bates 550 from Gabun. Pieper adds Dinklage 1905 from Liberia.

Cotypes of V. bipindensis are Zenker 1351, 1893, 1915, 1915a, and 2164 from Cameroons. According to Pieper, the flower-color difference cited by Gurke as the distinguishing feature between V. grandifolia and V. bipindensis is not dependable. Pieper reduces the latter to varietal rank under V. grandifolia, the variety having its calyxes $3--5$ or rarely $6 \mathrm{~mm}$. long, while in the typical form it is only $3--3.5 \mathrm{~mm}$. Iong. Besides the cotype collections he cites under the variety Zenker 959, Staudt 136, Nildbraed 5658, Tessmann B.193, Ledermann 1135, Buesgen 72a, Zahn 504, Preuss s.n., and Winkler 5la, 118, and 1165 , all from the Cameroons. I doubt very much whether the variety is worthy of being retained as distinct.

Citations: SIERPA LEONE: Deighton $2336(\mathrm{~K}, \mathrm{~N})$; G. Mann 380 (V). LIBERIA: J. T Baldwin, Jr., 6301 (N) $6489(\bar{N}), \overline{14818(N)}$. CAYrRoONS: Naitland 361 (K, Ni); Staudt 136 (S); Zenker 959 (S), $1351(\mathrm{~N}, \mathrm{~N}, \overline{\mathrm{S}}), 1393 \overline{(\mathrm{N}}-$-photo, $\overline{\mathrm{S}, \mathrm{Z}-\mathrm{p} \text { hoto }), 19 \overline{15}(\mathrm{~S})}, \overline{1915 \mathrm{a}}$ $\overline{(S)}, 2164$ (S), s.n. [Bipindi, lay 1897] (iv). FRENCH EQUATORIAL AFIRICA: Gabun: Klaine s.n. (S). CULTIVATED: Cameroons: Versuchsanstalt Kamerun 504 (N--photo, Us, Z--photo).

VITEX GRISEA J. G. Baker in Thiselt.-Dyer, Fl. Trop. Afr. 5: 325 . 1900.

Synonymy: Vitex huillensis Hiern, Cat. Afr. Pl. Welw. 4: 837. 1900.

Literature: J. G. Baker in Thiselt.-Dyer, Fl. Trop. Afr. 5: 325. 1900; Hiern, Cat. Afr. P1. Welw. 4: 837. 1900; Gurke in Baum, Kunene-Sambesi Exped. 350. 1903; Pieper in Engl., Bot. Jahrb. 62, Beibl. 141 ["142"]: 48, 61, 82, \& 83. 1928; Noldenke, Known Geogr. Distrib. Verbenac., [ed. 1], 50, 51, \& 103 (1942) 
and [ed. 2], 117, 119, \& 201. 1949.

Tree; branchlets densely short-pubescent, the hairs drab; leaves usually $5-f o l i o l a t e ; ~ p e t i o l e s ~ 5--7.5 \mathrm{~cm}$. long; leafletblades subcoriaceous, oblong-cuneate, acute at the apex, entire, subsessile, obscurely pubescent above when mature, finely pubescent throughout beneath, the terminal one $7 \cdot 5--10 \mathrm{~cm}$. long and $2.5--3 \mathrm{~cm}$. wide at the middle; cymes dense, axillary, shortpedunculate, the peduncle and inflorescence-branches densely pubescent; calyx campanulate, about $2 \mathrm{~mm}$. long, densely pubescent, its rim distinctly dentate with deltoid teeth; corolla small, hairy on the outer surface; fruit not known.

The type of this species is Welwitsch 5759 from an altitude of 3300--5500 feet, Huilla, Angola. Pieper cites, in addition, sunzner 65 from Msamvia, Tanganyika Territory. The specimen cited by Gurke as $\mathrm{V}$. huillensis in the reference given above is actually V. hockii DeWild.

VITEX GRISEA var. DEKINDTIANA (Gurke) Pisper in Engl., Bot. Jahrb. 62, Beibl. 141 ["142"]: 61. 1928.

Synorymy: Vitex dekindtiana Gurke in Engl., Bot. Jahrb. 32: 143. 1902.

Literature: Gurke in Engl., Bot. Jahrb. 32: 143. 1902; Pieper in Engl., Bot. Jahrb. 62, Beibl. 141 ["142"]: 61 \& 82. 1928; l.oldenke, Known Geogr. Distrib. Verbenac., [ed. 1], 51 \& 103. 1942; H. N. \& A. L. Moldenke, Pl. Life 2: 55 . 1948; Moldenke, Known Geogr. Distrib. Verbenac., [ed. 2], 119 \& 201.1949.

This variety differs from the typical form of the species in its shorter internodes, which are very much abbreviated at the tips of the shoots. It appears to represent merely a stunted form in which the leaves have developed more quickly and uniformly, but the stem growth has become retarded. It is doubtful whether it deserves taxonomic recognition. Pieper cites only Dekindt 444 and Antennes 364 from Huilla, Angola.

VITEX GUERKEANA Hiern, Cat. Afr. P1. Welw. 1 (4): 835. 1900 [not pearson, $\frac{V_{0}}{\text { 1923]. }}$ guerkeana Dewild., 1909, nor Engl., 1916, nor H. H. W.

Synonymy: Vitex mufescens Gurke in Engl., Bot. Jahrb. 18: 169. 1894 [not V. rufescens A. L. Juss., 1806]. Vitex ferruginea Baker, in part, apud Pieper in Engl., Bot. Jahrb. 62, Beibl. 14I ["142"]: 58 \& 70 , in syn. 1928 [not V. ferruginea Schum. \& Thonn, 1327].

Literature: Gurke in Engl., Dot. Jahrb. 13: 169. 1394; Hiern, Cat. Afr. Pl. Welw. I (4): 835. 1900; Pieper in Engl., Bot. Jahrb. 62, Beibl. Ilil ["14,2"]: 45, 59, 70, 82, \& 34. 1923; Noldenke, Known Geogr. Distrib. Verbenac., [ed. 1], 51 \& 103. 1942; H. N. 2 A. L. Holcienke, PI. Life 2: 62. 1948; l.olcenke, Known Geogr. Distrib. Verbenac., [ed. 2], 119 \& 201.1949.

Plont more or less densely pubescent throughout, with light red-brown hairs; leaves 5--7-foliolate; leaflet-blades elongateobovate, entire, densely pubescent beneath; flowers about $6 \mathrm{~mm}$. long; calyx weakly zygomorphic, to $2.5 \mathrm{~mm}$. long, its tecth $1 / 5$ 
to $1 / 4$ the length of the calyx, its hairs multicellular, at least at the base; ovary usually densely glanduliferous, glabrous throughout.

A notation on the Kew sheet of Welwitsch 5632 indicates that Bak $\rightarrow r$ reduced $V$. guerkeana Hiern (V. rufescens Gurke) to synonymy under $\mathrm{V}$. fermuginea Schum. \& Thonn. only "ex description". Pieper, however, points out that the statement in the original diagnosis to the effect of "foliola utrinque glabra, germen apice pubescens" clearly indicates that there are two distinct species involved. Pieper was able to see authentic material of both species. He cites for $\mathrm{V}$. guerkeana the following collections: Welwitsch 5632, 5654, and 5712, all from Golungo Alto in Angola. Vitex guerkeana Deilild. is a synonym of $\mathrm{V}$. volkensii Gurke, $\mathrm{V}$. guerkeana Engl. is V. payos (Lour.) Merr., and V. gurkeana H. H. W. Pearson is V. pearsonii Pieper.

VITEX GUERKEANA var. GOSSWEILERI Pieper in Ingl., Bot. Jahrb. 62, Beibl. 141 ["142"]: 58. 1928.

Literature: Pieper in Engl., Bot. Jahrb. 62, Beibl. 141 ["142"]: 58 \& 82. 1928; Moldenke, Known Geogr. Distrib. Verbenac, [ed. 1], 51 \& 103. 1942; H. N. \& A. L. Moldenke, PI. Life 2: 62. 1948; Voldenke, Known Geogr. Distrib. Verbenac., [ed. 2], 11.9 \& 201. 1949.

This variety differs from the typical form of the species in having firmer leaf-blades and in having the ultimate branches of the inflorescence and the flowers yellowish.

It is based on Gossweiler 662 from the Cazengo district of Angola.

VITEX GUIANENSIS Moldenke, Alph. List Common Names 14, nom. nud. (1939); Phytologia 1: 486--487. 1341.

Literature: Koldenke, Alph. List Common Names 14. 1939; Voldenke, Geogr. Distrib. Avicenn. 21. 1939; l:oldenke, Phytologia 1: 436--487. 1941; Moldenke, Know Geogr. Distrib. Verbenac., [ed. 1], 33 \& 103. 1942; l'oldenke, Phytologia 2: 120. 1944; Moldenke, Known Geogr. Distrib. Verbenac., [ed. 2], 67 \& 201. 1249.

Tree, to $30 \mathrm{~m}$. tall, slightly buttressed, inclined to be fluted; bark pale-gray, thin, papery; branchlets rather slencier, obtusely tetragonal, densely tomentose with rufescent rather short hairs, the tomentum wearing off in age; nodes annulate, flattened; principal internodes $2-6 \mathrm{~cm}$. long; leaf-scars rather large and prominent; leaves deciduous, strongly scented, 5-foliolate; petioles very slender, $4--10$ (-- 3.3 .5 ?) $\mathrm{cm}$. long, densely rufescent-tomentose (in age stout and glabrous ? -- one old petiole, without leaflets, is mounted on an isotype, but may not belong to this species); leaflets thin-chartaceous or submembranous, dark-green above, slightly lighter beneath, unequal, the 2 lowermost mostly considerably smaller than the rest, siort-petiolulate; petiolules very slender, $1.5--4 \mathrm{~mm}$. long, densely rufescent-tomentose; central leaflet-blades elliptic, $8.6--15.5 \mathrm{~cm}$. long, $3.1--6.8 \mathrm{~cm}$. wide, acute or short-acuminate at the apex, 
entire or obscurely repand-undulate, acute or short-acuminate at the base, sparsely hirsutulous above with scattered ferruginous hairs, very densely so along the midrib and larger veins, somewhat more densely hirsutulous beneath, especially alon the larger venation; midrib slender, flat above, prominent beneath; secondaries very slender, $10--15$ per side, arcuate-ascending, mostly flat and rather obscure above, prominulous beneath, (indistinctly) anastomosing in many loops at the margins; veinlet reticulation indiscernible above, the larger portions slightly prominulous beneath; infloresconce axiljary; cymes abbreviated, much shorter than the petioles; peciuncles, pedicels, and young shoots covered with a brown felt of hairs; flowers in erect umbelloid cymes; calyx pale-reen, erecto-patent; corolla bilabiate, the upper lip composed of 2 white reflexed lobes, the lower lip composed of 3 blue-purple lobes, with a patch of pale-yellow hairs at the base of the central lobe, reflexed; corolla-tube blue-striate; filaments up to $1 / 4$ longer than the corolla-tube, flushed with purple; anthers blue; fruit not known.

The type of this species was collected in myrtaceous baniaballi bush on the top of Ironstone Hill where there was no uniform soil covering, but only soil pockets, in British Guiana (Eritish Guiana Forest Dept. 2543) on October 28, 1937, and is deposited in the herbarium of the Royal Botanic Gardens at Kew. The native Arawak name is "hakiaballi".

Citations: BRITISH GUIANA: British Guiana Forest Dept. 2543 [field no. 9] (K--type, $\mathrm{K}$--isotype, N--isotype, N--photo of type, Z--photo of type).

VITEX HARVEYANA H. H. W. Pearson in Thiselt.-Dyer, Fl. Cap. 5: 212--213. 1901.

Synonymy: Vitex schlechteri Gurke in Engl., Bot. Jahrb. 33: 299. 1904 .

Literature: H. H. "W. Pearson in Thiselt.-Dyer, Fl. Cap. 5: 212--213. 1901; Gurke in ingl., Bot. Jahrb. 33: 299. 1904; Pieper in Engl., Bot. Jahrb. 62, Beibl. 141 ["142"] : 43, 56, 32 , \& 34. 1928; Nolcenke, Known Geogr. Distrib. Verbenac., [ed. 1], 51, 52, 103, 2: 104. 1942; H. I. \& A. L. Moldenke, PI. Life 2: 63 2. 31. İli3; Koldenke, Known Geogr. Distrib. Verbenac., [ec. 2], 120, 122, 201, \& 202. 1949.

Woody bush or shrub, 2--2.7 m. tall; int rnodes elongate; branches tetragonal, striate, appressed-puberulent or appressedpubescent when young, especially at the nodes; leaves decussateopposite, 3--5-foliolate; petioles slender, 3--25 m. long; leaflet-blades subcoriaceous, obovate, subsessile or short-petiolate, $3.2--5.2 \mathrm{~cm}$. long, $1.3--2 \mathrm{~cm}$. wide, varying from acute or acuminate to obtuse or rounded at the apex, cuneate at the base, entire or 1--7-serrate on each side above the midile, glabrous on both surfaces except for tufts of hairs in the veirn-axils beneath, minutoly glandular, the lateral ones often much smaller; petiolules obsolete or to $7 \mathrm{~mm}$. long, grooved; secondaries 5--8 per side, ouscure above, prominent beneath; cymes pedunculate, axillary, loosely divaricate, few-flowered, usually exceeding 
the subtending leaves, bracteate, pubescent at the nodes, otherwise appressed-puberulent or glabrous; peduncles flattened, 2.5$4.5 \mathrm{~cm}$. long, puberul=nt; bractlets subulate or narrow-spatulate, 3--9 mm. long, puberulent or glabrous; pedicels short, 2-bracteolate; calyx cupuliform, $2.5--3.5 \mathrm{~mm}$. long, 10-nerved, glabrous within, pubescent and minutely glandular outside, its rim subtruncate or very slightly 5-toothed; corolla pale-blue, its tube slightly curvate, 6--3 mm. long, glabrous within, pubescent outsicle above the middle, glabrous below the midale, its limb ultimately reflexed, the anterior lip pubescent within at the base, minutely so outside; stamens inserted at about the middle of the corolla-tube, inclucied; filaments ampliate and villous at the base; ovary subglobose, glabrous; fruit drupaceous, spherical or suboblong, dar exserted from the slightly accrescent fruitingcalyx, slabrous, about $3 \mathrm{~mm}$. in cliameter, with a thick woody endocarp.

The species is based on Gerard \& licken 1250 from the banks of the Upper Tugela River, Natal, and Haygarth s.n. [Wood 7462] from an altitude of 100 feet in Zululand. The type of V. schlechteri is schlechter 11731 from Komati Poort in Transvaal.

1:eeuse, in a letter to me dated December 9, 1953, states that he feels that $\mathrm{V}$. geminata $\mathrm{H}$. H. ".. Pearson, $\mathrm{V}$. mombassae Vatke (including $V$. flavescens Rolte and V. Eoetzei Gurke), V. pooara Corbishley, and possibly $\mathrm{V}$. isotjensis Gibbs belong in the synonymy of $\mathrm{V}$. harveyana. He bases this conclusion on examinations by an associate of the isotypes at Kew and by comparison of notes and specimens with Dr. H. Wild in Salisbury, Southern Rhodesia. Pieper, however, not only keeps these apart, but also keep apart $\mathrm{V}$. harveyana and V. schlechteri. lle says that the former has 3foliolate leaves, petioles mostly only to $2 \mathrm{~cm}$. long, and pedicels to $6 \mathrm{~mm}$. long, while the latter has 5-foliolate leaves, petioles $2--2.5 \mathrm{~cm}$. long, an edicels $6--1.0 \mathrm{~mm}$. long. He notes that $\mathrm{V}$. wilmsii Gurke, said to be a close relative, has only superficial habital likenesses anc. actually belongs in the subE`nus Holmskioldiopsis.

V. harveyana is saj.d to grow in low velt bush in dry watercourses, at altitudes of 100 to 1100 reet. It has been collected in flower in lay and in fruit in April.

Citations: PORTUGUES EAST APICA: Lourenço Varques: Borle 157 (Af, N--photo, Z--photo). UIION OF SOUTH AFliCA: Natal: Gerstner s.n.(Na--22252); Haygarth s.n. [Wood 7462] (N--cotype, il--photo of cotype, Na-3620--cotype, S-photo of cotype, z--photo of cotype). Transvaal: Codd 5514 (Z); Rodin 4232 (N, S); F. A. Rogers 13278 (Na--15691); Schlechter $117 \overline{31}(\bar{N}, \overline{N--p h o t o, ~ S, ~ Z--p h o t o) . ~}$

VITEX HAUSKNECHTII Bornm., Beih. Bot. Centralbl. 22 (2): 118. 1907.

Synonymy: Vitex agnus castus var. micrantha Hausskn. ex Bornm., Beih. Bot. Centralbl. 22 (2): 118, in syn. 1907. Vitex haussknechtii Bornm., Notizbl. Bot. Gart. Berlin 7: $25.1 \overline{917}$. 
Literature: Bornm., Beih. Bot. Centralbl. 22 (2): 113. 1907; Prain, Ind. Kew. Suppl. 4: 248. 1913; Bornm., Notizbl. Bot. Gart. Berlin 7: 25. 1917; Moldenke, Suppl. List Invalid Names 11. 1941; Moldenke, Known Geogr. Distrib. Verbenac., [ed. 1], 53 \& 103. 1942; Moldenke, Alph. List Invalid Names Suppl. 1: 28. 1947; H. N. \& A. L. Moldenke, Pl. Life 2: 63. 19L8; Moldenke, Known Geogr. Distrib. Verbenac., [ed. 2], 124 \& 201.1949.

Bornmtuller originally published this name as a binomial, but called it "subspec. nov." and referred to it as an "Unterart". In the Notizblatt reference, cited above, the original citation is written, in error, as having appeared in volume 20 of the Beihefte, instead of volume 22.

The species differs from the typical $\mathrm{V}$. agnus-castus L., of which it is said to be a subspecies, in having its flowers very small, measuring only $5 \mathrm{~mm}$. from the base of the calyx to the anthers (or only half as long as in typical V. agnus-castus), the corolla-tube is only twice (instead of thrice) the length of the $1.5 \mathrm{~mm}$. long calyx, the spikes are slender, thin, short, all congested at the apex of the branches into a many- [8- or 9-] branched, ovate, subaphyllous panicle which is $10--12 \mathrm{~cm}$. long and $5--6 \mathrm{~cm}$. wide, and the cymes are small and laxly flowered. Otherwise its characters are those of $\mathrm{V}$. agnus-castus.

The type of the species is Haussknecht s.n., collected at Varasch, near Dschiham Koprt, Syria, on July 12, 1865. It is known thus far only from the type collection.

VITEX HAVILANDII Ridl., Kew Bull. 1929: 262. 1929.

Literature: Ridl., Kew Bull. 1929: 262. 1929; Hill, Ind. Kew. Suppl. 8: 249. 1933; Moldenke, known Geogr. Distrib. Verbenac., [ed. 1], 65 \& 103. 1942; H. N. is A. L. Moldenke, Pl. Life 2: 63. 1948; Moldenke, Known Geogr. Distrib. Verbenac., [ed. 2], 145, 146 , \& 201 . 1949 .

Small tree; branchlets puberulent; leaves l-foliolate; petioles $1.5--2 \mathrm{~cm}$. long, incrassate at the apex; leaflet-blades coriaceous, lanceolate, $3--11 \mathrm{~cm}$. long, $3--5 \mathrm{~cm}$. wide, obtuse at the base, cuspidate at the apex, with the cusp $1--1.5 \mathrm{~cm}$. long; midrib prominent on both surfaces; secondaries about 9 per side, inwardly arched about $2 \mathrm{~mm}$. from the margins, prominent beneath; vein and veinlet reticulation conspicuous; panicle lax, fewflowered, located in the upper leaf-axils, $5--3 \mathrm{~cm}$. long, puberulent, its branches $1--3 \mathrm{~cm}$. long; flowers small, 2 or 3 on each short branch; pedicels about $1 \mathrm{~mm}$. long; bractlets linear, about $1 \mathrm{~mm}$. long, acuminate; ca? yx cupuliform, about $2 \mathrm{~mm}$. long, its rim 5-toothed, the teeth very short, acute or subacute; corolla about $6 \mathrm{~mm}$. long, its tube glabrous at the base, pubescent above, its 4 lobes oblong and obtuse, the labellum rounded and entire; ovary globose, sunken in the calyx.

$\mathrm{T}_{\mathrm{h}}$ e species is based on Haviland 861 and is reported also from Sarawak. It is said to be a tree 30 feet tall, with white flowers, blooming in August, growing at an altitude of 15 meters in British North Borneo.

Citations: BRITISH NORTH BORNEO: Agama 575 [128] (N--photo, 
Ph, Z--photo).

VITEX HAYNGA Roxb., Hort. Beng. 46, hyponym. 1814.

Literature: Roxb..., Hort. Beng. 46. 1814; Jacks., Ind. Kew. 2: 1213, 1895; Moldenke, Known Geogr. Distrib. Verbenac., [ed. 1], $55 \& 103$ (1942) and [ed. 2], $128 \& 201.1949$.

I know nothing about this species except that Roxburgh says that it grows in the Chittagong area of West Bengal, where it is known as "haynga".

VITEX HEMSLEYI Briq., Bull. Herb. Boiss. 4: 347. 1896.

Synonymy: Cornutia pentaphylla Sessé \& Moc., La Naturaleza, ser. 2, 1: app. 103. 1889 [not C. pentaphylla Pavon, 1936, nor Vitex pentaphylla Merr., 1909]. Vitex capulin Pittier, Contrib. U. S. Nat. Herb. 20: 485--486. 1922. Vitex leucoxilon Sessé \& Noc. ex Moldenke, Prelim. Alph. List Invalid Names 51, in syn. 1940 [not V. leucoxylon L. f., 1781]. Vitex oaxacona Briq. ex Moldenke, Suppl. List Invalid Names 11, in syn. 194l. Vitex oaxacana Briq. ex Moldenke, Alph. List Invalid Names 54, in syn. 1942.

Literature: Sessé \& Moc., La Naturaleza, ser. 2, 1: app. 103. 1889; Briq., Bull. Herb. Boiss. 4: 347. 1896; Merr., Philipp. Journ. Sci. Bot. 4: 320. 1909; Pittier, Contrib. U. S. Nat. Herb. 20: 485--486. 1922; Moldenke, Alph. List Common Names 7. 1939; Moldenke, Geogr, Distrib. Avicenn. 14. 1939; Moldenke, Prelim. Alph. List Invalid Names 23, 50, \& 51. 1940; Moldenke, Suppl. List Invalid Names 11. 194l; Moldenke, Alph. List Invalid Names 22 \& 52--54. 1942; Moldenke, Known Geogr. Distrib: Verbenac., [ed. 1], 19 \& 103. 1942; Moldenke, Phytologia 2: 120. 1944; W. C. Leavenworth, Am. Midl. Nat. 36: 146, 147, \& 187. 1946; H. N. \& A. L. Moldenke, Pl. Life 2: 63. 1948; Moldenke, Known Geogr. Distrib. Verbenac., [ed. 2], 33 \& 201. 1949; H. N. \& A. L. Moldenke, Anal. Inst. Biol. Mexico 20: 15. 1949.

Tree, to $12 \mathrm{~m}$. tall; branches and branchlets slender, obtusely tetragonal, prominently lenticellate, more or less puberulent, becoming glabrate in age; nodes annulate; principal internodes 6--12 mm. long; leaf-scars very large, with prominent edges, not borne on noticeable sterigmata; leaves decussate-opposite, 5foliolate; petioles slender, $1.5--4.5 \mathrm{~cm}$. long, flattened above and only very slightly margined, not canaliculate, convex beneath, puberulent; petiolules slender, $1--5 \mathrm{~mm}$. long, broadly margined, sparsely puberulent; leaflet-blades chartaceous, rather uniformly dark-green on both surfaces or slightly lighter beneath, the terminal one elliptic, $4--13.2 \mathrm{~cm}$. long, $1.2--4.6 \mathrm{~cm}$. wide, acute or obtuse at the apex, entire, acute at the base, very sparsely and obscurely pulverulent along the larger venation or glabrous and shiny on both surfaces; midrib slender, slightly prominulent or subimpressed above, rounded-prominent beneath; secondaries slender, 10--14 per side, arcuate-ascending, rather short, plane or obscure above, subprominulent beneath, rather indistinctly arcuate-joined near the margins. 


\section{$2 \mathrm{BHL}$ Biodiversity Heritage Library}

Moldenke, Harold N. 1956. "Materials toward a monograph of the genus

Vitex. V." Phytologia 5, 343-393. https://doi.org/10.5962/bhl.part.12991.

View This Item Online: https://www.biodiversitylibrary.org/item/47042

DOI: https://doi.org/10.5962/bhl.part.12991

Permalink: https://www.biodiversitylibrary.org/partpdf/12991

\section{Holding Institution}

New York Botanical Garden, LuEsther T. Mertz Library

\section{Sponsored by}

The LuEsther T Mertz Library, the New York Botanical Garden

\section{Copyright \& Reuse}

Copyright Status: In copyright. Digitized with the permission of the rights holder.

Rights Holder: Phytologia

License: http://creativecommons.org/licenses/by-nc-sa/3.0/

Rights: https://biodiversitylibrary.org/permissions

This document was created from content at the Biodiversity Heritage Library, the world's largest open access digital library for biodiversity literature and archives. Visit BHL at https://www.biodiversitylibrary.org. 